\title{
JSIOU
}

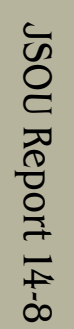

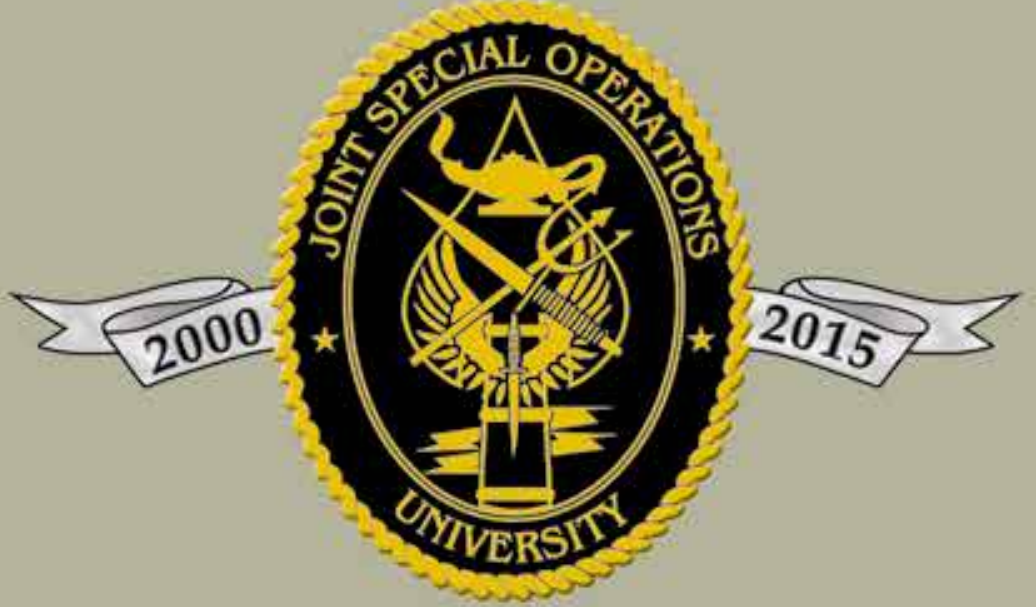

Joint Special Operations University 7701 Tampa Point Boulevard MacDill AFB FL 33621

\section{Islam: Ideology and Conflict}

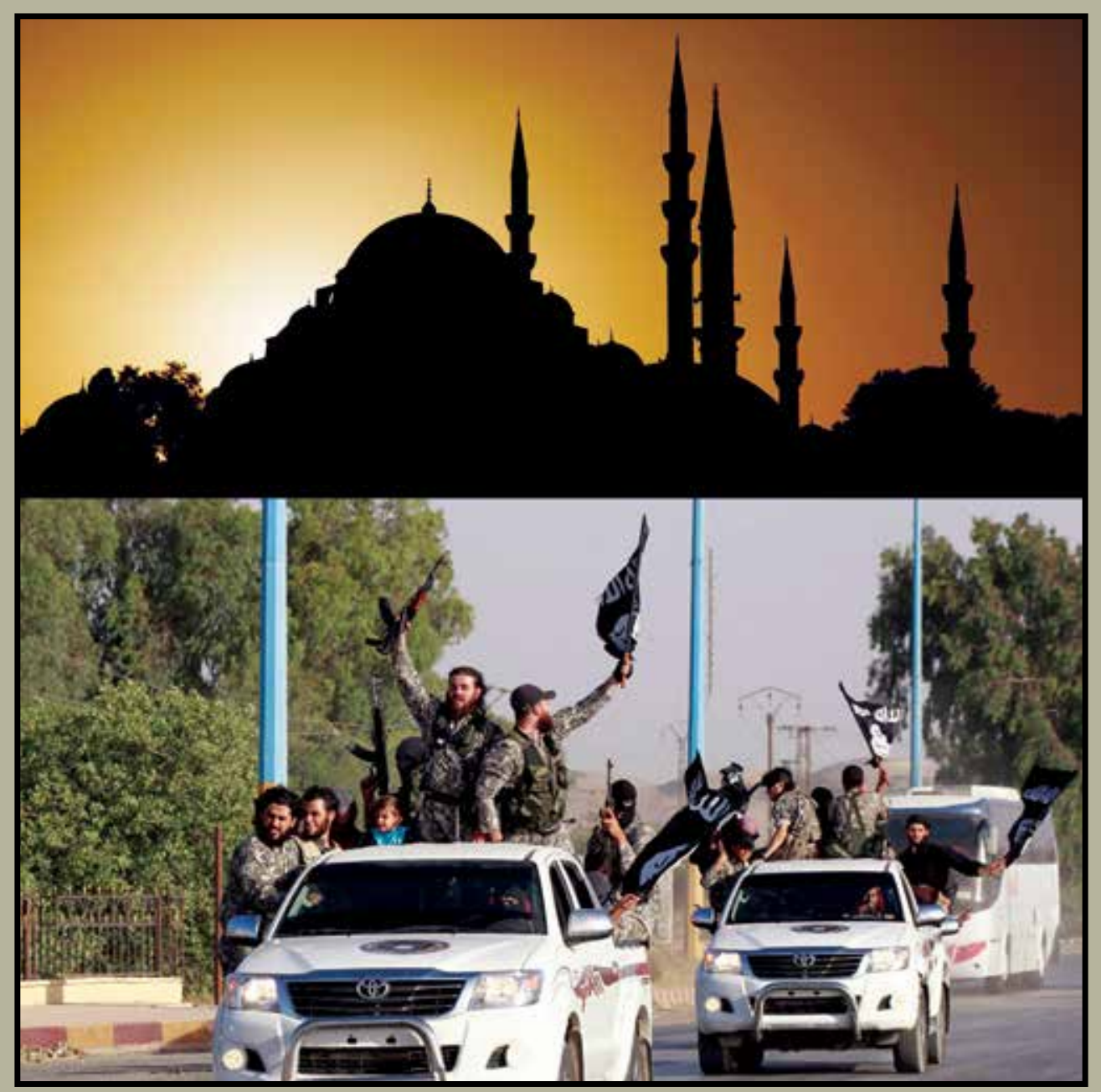

https://jsou.socom.mil

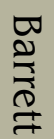




\section{Report Documentation Page}

Form Approved

OMB No. 0704-0188

Public reporting burden for the collection of information is estimated to average 1 hour per response, including the time for reviewing instructions, searching existing data sources, gathering and maintaining the data needed, and completing and reviewing the collection of information. Send comments regarding this burden estimate or any other aspect of this collection of information,

including suggestions for reducing this burden, to Washington Headquarters Services, Directorate for Information Operations and Reports, 1215 Jefferson Davis Highway, Suite 1204, Arlington

VA 22202-4302. Respondents should be aware that notwithstanding any other provision of law, no person shall be subject to a penalty for failing to comply with a collection of information if it

does not display a currently valid OMB control number.

\begin{tabular}{|c|c|c|}
\hline $\begin{array}{l}\text { 1. REPORT DATE } \\
\text { DEC } \mathbf{2 0 1 4}\end{array}$ & 2. REPORT TYPE & $\begin{array}{l}\text { 3. DATES COVERED } \\
\mathbf{0 0 - 0 0 - 2 0 1 4} \text { to 00-00-2014 }\end{array}$ \\
\hline \multirow{3}{*}{\multicolumn{2}{|c|}{$\begin{array}{l}\text { 4. TITLE AND SUBTITL } \\
\text { Islam: Ideology and Conflict }\end{array}$}} & 5a. CONTRACT NUMBER \\
\hline & & 5b. GRANT NUMBER \\
\hline & & 5c. PROGRAM ELEMENT NUMBER \\
\hline \multirow{3}{*}{\multicolumn{2}{|c|}{ 6. AUTHOR(S) }} & 5d. PROJECT NUMBER \\
\hline & & 5e. TASK NUMBER \\
\hline & & 5f. WORK UNIT NUMBER \\
\hline \multicolumn{2}{|c|}{$\begin{array}{l}\text { 7. PERFORMING ORGANIZATION NAME(S) AND ADDRESS(ES) } \\
\text { Joint Special Operations University,7701 Tampa Point } \\
\text { Boulevard,MacDill AFB,FL,33621 }\end{array}$} & $\begin{array}{l}\text { 8. PERFORMING ORGANIZATION } \\
\text { REPORT NUMBER }\end{array}$ \\
\hline \multirow{2}{*}{\multicolumn{2}{|c|}{ 9. SPONSORING/MONITORING AGENCY NAME(S) AND ADDRESS(ES) }} & 10. SPONSOR/MONITOR'S ACRONYM(S) \\
\hline & & $\begin{array}{l}\text { 11. SPONSOR/MONITOR'S REPORT } \\
\text { NUMBER(S) }\end{array}$ \\
\hline
\end{tabular}

12. DISTRIBUTION/AVAILABILITY STATEMENT

Approved for public release; distribution unlimited

13. SUPPLEMENTARY NOTES

14. ABSTRACT

15. SUBJECT TERMS

16. SECURITY CLASSIFICATION OF:

\begin{tabular}{c|c|c|c|}
$\begin{array}{c}\text { a. REPORT } \\
\text { unclassified }\end{array}$ & $\begin{array}{c}\text { b. ABSTRACT } \\
\text { unclassified }\end{array}$ & $\begin{array}{c}\text { c. THIS PAGE } \\
\text { unclassified }\end{array}$ & $\begin{array}{c}\text { Same as } \\
\text { Report (SAR) }\end{array}$
\end{tabular}

\begin{tabular}{l|l}
$\begin{array}{c}\text { 18. NUMBER } \\
\text { OF PAGES } \\
\mathbf{1 1 2}\end{array}$ & 19a. NAME OF \\
&
\end{tabular}




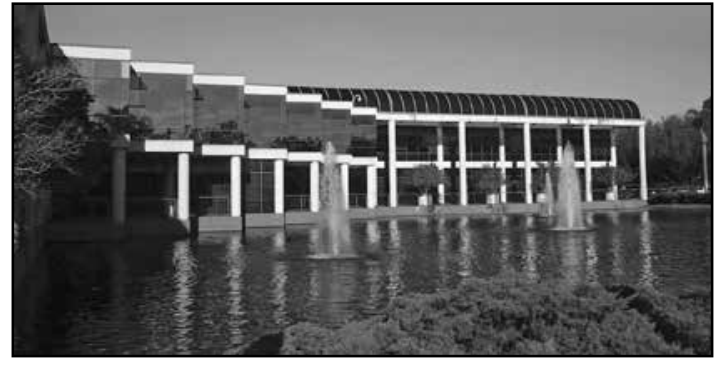

Joint Special Operations University and the Center for Special Operations Studies and Research

The Joint Special Operations University (JSOU) provides its publications to contribute toward expanding the body of knowledge about joint special operations. JSOU publications advance the insights and recommendations of national security professionals and the Special Operations Forces (SOF) students and leaders for consideration by the SOF community and defense leadership.

JSOU is the educational component of the United States Special Operations Command (USSOCOM), MacDill Air Force Base, Florida. The JSOU mission is to educate SOF executive, senior, and intermediate leaders and selected other national and international security decision makers, both military and civilian, through teaching, outreach, and research in the science and art of joint special operations. JSOU provides education to the men and women of SOF and to those who enable the SOF mission in a joint and interagency environment.

JSOU conducts research through its Center for Special Operations Studies and Research (CSOSR) where effort centers upon the USSOCOM mission:

USSOCOM mission. Provide fully capable Special Operations Forces to defend the United States and its interests. Synchronize planning of global operations against terrorist networks.

Press publications are available for download from the JSOU Library web page located at http://jsou.libguides.com/jsoupublications.

\section{Joint Special Operations University}

Brian A. Maher, Ed.D., SES, President

Kenneth H. Poole, Ed.D., Director, Center for Special Operations Studies and Research Robert Nalepa, Lt. Col., U.S. Air Force, Ret., Editor in Chief

Mark Moyar, Ph.D., History; Will Irwin, MMAS, Lieutenant Colonel, U.S. Army, Ret.; Peter McCabe, Ph.D., Political Science, Colonel, U.S. Air Force, Ret.; Gregory Salomon, Colonel, U.S. Army; Resident Senior Fellows Anna-Marie Wyant, M.A., English, JSOU Press Editor

Frederick Zimmerman, Master Sergeant, U.S. Marine Corps, Ret., JSOU Press Editor

\section{Editorial Advisory Board}

Roby C. Barrett

Ph.D., Middle Eastern \& South Asian History Public Policy Center Middle East Institute and JSOU Senior Fellow

Joseph D. Celeski

Colonel, U.S. Army, Ret. JSOU Senior Fellow

Chuck Cunningham

Lieutenant General, U.S. Air Force, Ret.

Professor of Strategy, Joint Advanced

Warfighting School and JSOU Distinguished Senior Fellow

James J.F. Forest

Ph.D., Higher Education Administration

Associate Professor, School of Criminology and

Justice Studies, University of Massachusetts

Lowell and JSOU Senior Fellow

Mario Forestie

Chief Warrant Officer, U.S. Army, Ret.

Director, Joint Special Operations Command

Center for Counterterrorism Studies

Thomas H. Henriksen

Ph.D., History, Hoover Institution

Stanford University and JSOU Senior Fellow

Bernd Horn

Colonel, Canadian Dept. of National Defence

Ph.D., War Studies

Director, CANSOFCOM Professional

Development Centre

Russell D. Howard

Brigadier General, U.S. Army, Ret.

Senior Research Fellow and adjunct professor,

Monterey Institute of International Studies and JSOU Senior Fellow

John D. Jogerst

Colonel, U.S. Air Force, Ret.

James Kiras

Ph.D., History, School of Advanced Air and Space Studies, Air University and JSOU Associate Fellow
William W. Mende Colonel, U.S. Army, Ret. JSOU Senior Fellow

Alvaro de Souza Pinheiro Major General, Brazilian Army, Ret. JSOU Associate Fellow

James F. Powers, Jr. Colonel, U.S. Army, Ret. ISOU Senior Fellow

Bryan C. Price

Major, U.S. Army Ph.D., Political Science Director, Combating Terrorism Center at West Point

Richard H. Shultz, Jr. Ph.D., Political Science Director, International Security Studies Program, The Fletcher School, Tufts University and JSOU Senior Fellow

Robert G. Spulak, Jr. Ph.D., Physics/Nuclear Engineering Sandia National Laboratories and ISOU Associate Fellow

Jessica Glicken Turnley Ph.D., Cultural Anthropology Galisteo Consulting Group and JSOU Senior Fellow

Francisco R. Wong-Diaz J.D., Ph.D., Political Science Professor of international affairs and law and JSOU Senior Fellow

\section{Rich Yarger}

Ph.D., History

ISOU Senior Fellow 


\section{On the cover.}

Top: Sulleymaniye Mosque silhouette. Photo via Newscom.

Bottom: Militant Islamist fighters wave flags as they take part in a military parade along the streets of Syria's northern Raqqa province June 30, 2014. Photo via Newscom. 

JOINT SPECIAL OPERATIONS

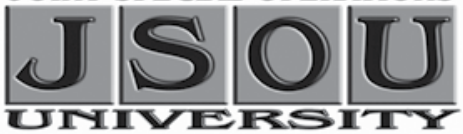

Islam: Ideology and Conflict

Roby C. Barrett

JSOU Press Report 14-8

The JSOU Press

MacDill Air Force Base, Florida

2014

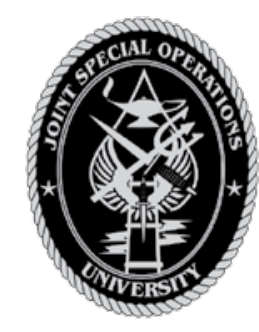


This monograph and other JSOU publications can be found at https://jsou. socom.mil. Click on Publications. Comments about this publication are invited and should be forwarded to the Director of the Center for Special Operations Studies and Research, Joint Special Operations University, 7701 Tampa Point Blvd., MacDill AFB FL 33621.

The JSOU Center for Special Operations Studies and Research (CSOSR) is currently accepting written works relevant to special operations for potential publication. For more information, please contact the CSOSR Director at jsou_research@socom.mil. Thank you for your interest in the JSOU Press.

This work was cleared for public release; distribution is unlimited. 
The views expressed in this publication are entirely those of the authors and do not necessarily reflect the views, policy or position of the United States Government, Department of Defense, United States Special Operations Command, or the Joint Special Operations University.

Authors are granted academic freedom provided their work does not disclose classified information, jeopardize operations security, or misrepresent official U.S. policy. Such academic freedom empowers authors to offer new and sometimes controversial perspectives in the interest of furthering debate on key issues. 
Recent Publications of the JSOU Press

Village Stability Operations and the Afghan Local Police, October 2014, Mark Moyar

Challenges in the Asia-Pacific Theater for U.S. and Partner Nation Special Operations Forces, October 2014, Robert Haddick

Counterinsurgency in Somalia: Lessons Learned from the African Union Mission in Somalia, 2007-2013, September 2014, Bronwyn E. Bruton, Paul D. Williams

U.S. Military Deployments to Africa: Lessons from the Hunt for Joseph Kony and the Lord's Resistance Army, August 2014, James Forest

Persistent Engagement in Colombia, July 2014, Mark Moyar, Hector Pagan, Wil R. Griego

Partners or Competitors? The Evolution of the Department of Defense/Central Intelligence Agency Relationship since Desert Storm and its Prospects for the Future, May 2014, David P. Oakley

Countering the al-Shabaab Insurgency in Somalia: Lessons for U.S. Special Operations Forces, February 2014, Graham Turbiville, Josh Meservey, James Forest

Strategic Culture, December 2013, Russell D. Howard

The Role of the Global SOF Network in a Resource Constrained Environment, November 2013

Piracy: The Best Business Model Available, November 2013, John Alexander The Terrorist Trafficking Nexus: Scourge of the World or So Much Hype?, October 2013, Russell D. Howard and Colleen Traughber 


\section{Contents}

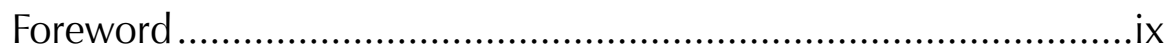

About the Author .......................................................................

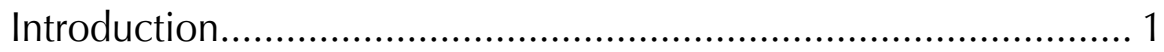

1. Islam: Diversity of Politics and Faith ……………………......... 9

2. The United States and the Wrong Side of Ideology .................... 23

3. The Islamic World: Politics and Extremism................................. 49

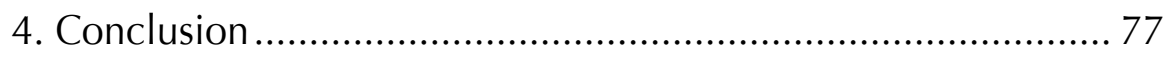

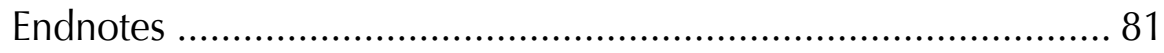





\section{Foreword}

$\mathrm{D}$

r. Roby Barrett takes on a monumental task in his monograph, 7slam:

Ideology and Conflict. This work is more than historical scholarship; it argues for an understanding of the Islamic World, Islam's roots and how those roots explain the political challenges of today. This is essential reading for anyone who is interested in making sense of sectarian violence, Middle East peace, and counterterrorism policies-for Islam is more than just a Sunni-Shia divide. There are layers of Islam that Dr. Barrett peels back to reveal the pretense that is the idea of Islam as an ideology. The central theme of this monograph is that Islam as a unified community is in actuality "imagined" communities fraught with fractures that help explain contemporary issues. This argument is broken down into three critical issues.

First, Dr. Barrett provides an overview of the conflicts in early Islam that are still the source of many conflicts today. Viewing the Islamic World as one entity or made up of major sects (Sunni and Shia) is misleading. Rather, a review of Islam's historical conflicts in the context of political, social, economic, and cultural issues allows the reader to understand that Islam cannot be assumed as a universalistic whole (i.e., Pan-Islamic movements). Just as Christianity cannot be viewed as a one-size-fits-all religion, Islam must be understood for what it is and is not. Islam is a complex religion with a vast history of internal conflict that speaks to contemporary issues today. Islam is not, as many in the West believe, a unity of belief and purpose that is tied to discussions on terrorism and radicalism.

Second, the shifting U.S. role relative to Islam is presented. The very forces with which we contend today have often been our allies in the past. The U.S., in its short history, has been involved with the Islamic World from the very start. It was a Muslim country, Morocco, which first recognized U.S. independence. ${ }^{1}$ However, as the U.S. role in the world grew, so did the conflict with Islam. The post-World War II era saw the U.S. break out onto the world stage; the discovery of Middle East oil brought Americans and American companies to the region; and U.S. recognition and support to Israel all brought the U.S. and Islam in conflict. Since 9/11, the U.S. has invaded two Muslim states, while at the same time trying to "win hearts and minds" in the Islamic World. According to the National Security Strategy (May 2010), 
"...this is not a global war against a tactic-terrorism or a religion-Islam." Negative Muslim perceptions of the U.S. need to be understood if there is any hope of reversing the trend.

Finally, the monograph deals with contemporary Islam, radicalism, and the issue of a fractured community. The current world of Islam is in many respects no different from the Islam during other periods in its history. Islam's internal conflict highlights the reason why Pan-Islamic movements never gain traction and the disjointed nature of radical Islam. While Islam might provide a common "cover story" for movements and groups, it is the local political, social, and cultural issues that are driving their policies and actions. Dr. Barrett posits that the West must focus less on Islam as an ideology and more on those local issues that drive the threat.

The insights provided by Dr. Barrett in this monograph challenge the reader to rethink how one approaches the challenges in the Middle East. The U.S. military and Special Operators in particular are involved in an ongoing conflict in a region they must understand before long-term solutions are feasible. The roots of the current conflict can be found in the past. Understanding the idea of unity in Islam (the "imagined community"), the changing role of the U.S. in the region, and the current fractured Islamic community will assist in refocusing efforts on the local level where gains can be achieved.

Kenneth H. Poole, Ed.D. Director, Center for Special Operations Studies and Research 


\section{About the Author}

$\mathrm{D}$ r. Roby C. Barrett is a senior fellow with the JSOU Strategic Studies Department. He has over 35 years of government, business, and academic experience in the Middle East and Africa. Dr. Barrett is the president of a consulting firm, specializing in technology applications and systems for national defense and security. He has extensive experience in space systems, nuclear issues, police and security systems, command and control, technology development, and weapons acquisition as they relate to both U.S. and allied governments. The current focus of his research is strategic security issues in the Persian/Arabian Gulf, including Islam, Iran, the Arabian Peninsula, and the collapse of state structure in the Levant. He is a former For-

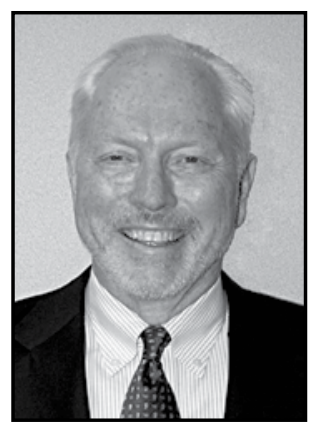
eign Service officer in the Middle East with a strong background in the cultural and political dynamics of historical Islamic and political development. His posting and other assignments included Tunisia, Yemen, Jordan, Lebanon, Egypt, Saudi Arabia, and the Arabian Gulf.

As a founder of the National History Center within the American Historical Association, Dr. Barrett specializes in the application of broad historical and conceptual paradigms to issues of ongoing political and military conflict and the projection of future trends. He is an area expert and fellow at the Middle East Institute (MEI) in Washington, D.C. He provides domestic and international media commentary on a range of issues from the Palestinian territories to nuclear proliferation and the challenges of Russian policy in the Middle East and North Africa. Initially trained as a Soviet and Russian specialist, Dr. Barrett brings unique insights to the regenerated competition between Russia, China, and the United States in the Middle East and Africa.

$\mathrm{He}$ also serves as the senior advisor to the Board of Directors of the Bilateral Arab-U.S. Chamber of Commerce, an organization whose members include major foreign and domestic petroleum companies. He is the lead panelist on Middle East and South Asian Policy. He also participates in the Congressional Fellowship Program, American Political Science Association, and Johns Hopkins School for Advanced International Studies in 
Washington, D.C. He has been a featured panelist for the German Council on Foreign Relations on Middle East and Gulf Affairs. Dr. Barrett also serves as a lecturer on Gulf affairs, Iraq, and U.S. foreign policy for the Air Force Special Operations Command and in response to special requirements.

Dr. Barrett was an Eisenhower-Roberts fellow of the Eisenhower Institute in Washington D.C., a Rotary International fellow at the Russian and East European Institute at the University of Munich, and a Scottish Rite Research fellow at Oxford University. He holds a B.A. in History and Political Science from East Texas State University and an M.A. in Political Science and Russian History from Baylor University. He is a graduate of the Foreign Service Institute's intensive 2-year Arab Language and Middle East Area Studies program and the Counterterrorism Tactics course and took part in the Special Operations course. He has a Ph.D. in Middle Eastern and South Asian History from the University of Texas (UT)-Austin. Other honors include the Guittard Fellowship (Baylor), the Dora Bonham Graduate Research Grant (UT-Austin), the David Bruton Graduate Fellowship (UT-Austin), the Russian Language Scholarship (Munich), and the Falcon Award from the U.S. Air Force Academy.

As an author, Dr. Barrett's works range from books to articles on the Arab League and digital research techniques: The Greater Middle East and the Cold War: U.S. Foreign Policy under Eisenhower and Kennedy (Palgrave Macmillan, 2007); "Intervention in Iraq, 1958-1959" in MEI Policy Briefs, 2008; The Arabian Gulf and Security Policy: The Past as Present, the Present as Future (JSOU Press, 2009); "The Aftermath of the 1958 Revolution in Iraq" in Ultimate Adventures with Britannia (I. B. Tauris, 2009); "Gulf Security: Policies without Context" in MEI Bulletin, 2010; Yemen: A Different Political Paradigm in Context (JSOU Press, 2011); Oman: The Present in the Context of a Fractured Past (JSOU Press, 2011); and Iran: Illusion, Reality and Interests (JSOU Press, 2012).

Dr. Barrett was a guest speaker at the Bahrain MOI Gulf Security Forum (2008), the SOF Conference at the opening of the King Abdullah Special Operations Training Center (Amman 2009), and the Bahrain SOF Conference (2010). Through deployment briefings and other forums, Dr. Barrett supported numerous military units; five examples are the 5th Special Forces Group and 101st Airborne, both in the U.S. and Iraq; Naval Special Warfare Command, both in the U.S. and the Arabian Gulf; 4th Psychological Warfare Group; and 19th Special Forces Group. He was a visiting professor at 
the Royal Saudi Arabian Command and Staff School (2010-2012). He also provides support to the Office of the Secretary of Defense, the Department of State, and the intelligence community.

His commentary has also appeared in the U.S., Latin American, European, and Middle East Press-for example, CCTV-America, Fox, CBS, ABC, National Public Radio, Voice of America English and Pakistan Services, British Broadcasting Corporation (BBC) World Service, Canadian National Broadcasting System, BBC Arabic Service, Gulf News, and The National Abu Dhabi. 


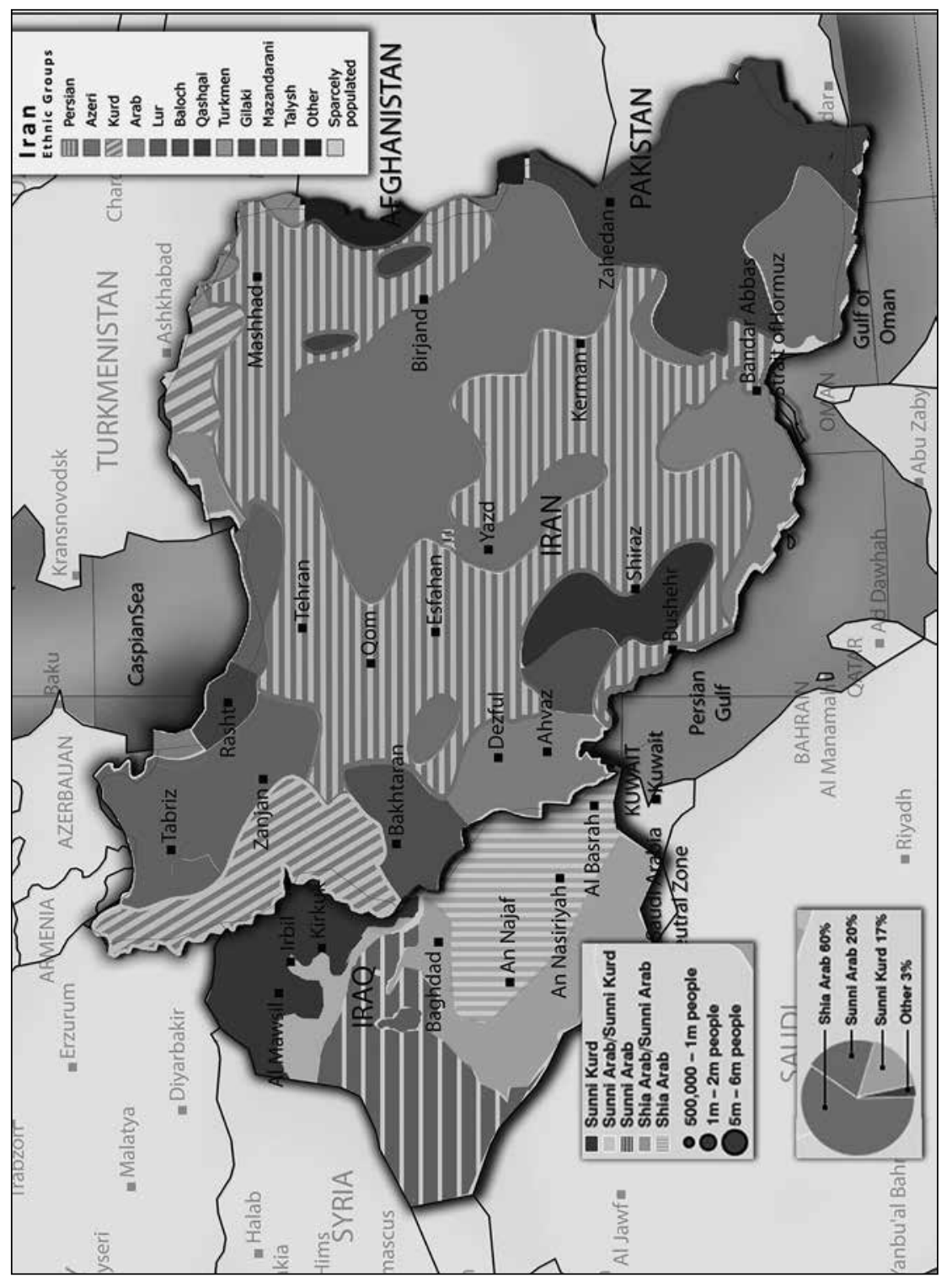

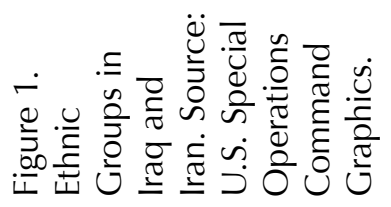




\section{Introduction}

A fter more than 200 years of sustained U.S. involvement with the Islamic World and 20 years of intense political and military intervention, misunderstandings persist in the United States with regard to Islam as an ideology and its functioning within the various political, economic, and social contexts. There is a persistent tendency to assume that knowledge and understanding of Islam is actually broader, more extensive, and sophisticated than is actually the case. From the perspective of U.S. policy and Special Operations Forces' (SOF) role in the execution of policy, three critical issues stand out. The first is the lack of knowledge of the basic ideological and political issues that persisted in early Islam and how those issues often form the ideological basis for struggles that confront SOF in contemporary Islamic societies. The second element is the apparent contradiction in U.S. policy in the Islamic World. The final factor is the political, economic, and social diversity within and between Islamic societies that drive diverse ideological interpretations of Islam that have far more to do with local environments than with any universal religious and theological views. This monograph approaches Islam and its role not as a universal, Unitarian creed that drives specific behaviors, but as the ideological backdrop for regional and local discontent that has created globalized security problems.

Categorizing political behavior as Muslim, or broad sectarian groupings as Sunni or Shi'a, is to misunderstand a complex relationship between religion as ideology and culture in the Islamic world. The politics of conflict are expressed using the verbiage of Islam, but at their core, they derive from historical political, economic, and social differences. Islam forms only a part of that milieu of instability and conflict. In most cases, Islam provides the medium for expression and discourse and should be understood in that more limited context. In short, SOF need to be able to penetrate the façade, i.e. the medium of expression and discourse, to understand the fundamentals of conflict in a specific environment. This is not only critical at an analytical level but extends down to training and operational teams as well. If SOF do not understand the language of conflict and how it plays a role in providing ideological motivation and differentiation between factions, groups, and subgroups, then how can it achieve its immediate operational or long-term strategic goals? 
The last decade has increased awareness of sectarian groupings; however, generalizations continue to distort an understanding of the situation on the ground and thus the SOF operating environment. The level of understanding of Islamic groups needs to be as deep as possible. This study focuses on the necessity of understanding the granularity of Islam and recalibrating and expanding the baseline knowledge related to Islam's role in specific political, economic, and social environments. This monograph is not about theology, but rather will focus on Islam as an ideological paradigm for legitimizing grievances that drive unrest and instability.

Philip Gordon, in Winning the Right War, stated, "[A] serious misconception of the current American approach is the failure to recognize the differences within the Islamic world." 3 The purpose of this study is to focus on Islam not as a limited subset of sects but as the ideological overlay for local and regional culture and conflicts. More than a war against the West, the current upheaval in the Islamic world constitutes an Islamic civil war in which the U.S. finds itself engaged in an attempt to protect its interests and those of the West. This civil war is driven by a myriad of complex and often conflicting factors in which radicalized politics is usually driven ideologically by interpretations of Islam that reflect the grievances of a specific geopolitical and socioeconomic setting.

As the U.S. attempts to sort out policies from the Philippines to Morocco and the Swahili coast to Chechnya, SOF's continuing engagement in this complex struggle requires a more complex paradigm for understanding and assessing political movements in the Islamic world. This study proposes a different approach to thinking about Islam and how its ideological role often provides the façade for existing conflicts (i.e. national, economic, confessional, tribal, ethnic, et cetera). It focuses on how different groups use Islam as justification and motivation in temporal power struggles that in reality have little to do with theology. Such a paradigm not only argues against any lingering notions that Islam is the core of the problem, but it also underscores the utility of a more sophisticated view of Islamic groups and movements that reflects the particular environment on the ground as opposed to centering in on the ideological justification or façade. ${ }^{4}$

A 2012 Rand Report on Al Qaeda by Brian Michael Jenkins pointed out:

Al Qaeda survives best where it can attach itself to deeply rooted local movements, which it then proceeds to radicalize. Over time, 
some of al Qaeda's partners become affiliates, adopting al Qaeda's ideology, incorporating its tactics, eventually assuming the al Qaeda brand name.

This underscores the essential role of local conflicts and rivalries. ${ }^{5}$ To a significant degree, this paper argues that if American policy makers globalize the security threat with an obsession with al-Qaeda, it obscures the real challenge which is grounded in local and regional political, economic, social, and cultural conflict. For SOF, the issue of combatting violent extremist organizations (VEOs) and promoting stability is first and foremost associated with local conflicts and frictions.

This study approaches this highly complex topic in three parts: the first element is the historical context into which the early Islamic state functioned, a snapshot of the reality of early Islam against the backdrop of how it is recalled or imagined by various groups; the second is an introduction to the dramatic shifts in U.S. policy over the last six decades; and third is a discussion of sectarianism as a product of historical, economic and social factors rather than an outgrowth of theological or religious differences and belief.

Because so much of the Islamic discourse-the rhetoric associated with legitimacy of policies and movements-harkens back to the belief in a purer Islamic age and attempts to recapture it, it follows that an introduction to early Islam or rather the reality of early Islam is a first step in penetrating the façade of contemporary Islamic discourse. The first chapter addresses early Islamic unity (tawhid) of the Muslim community (umma) as it actually existed. The term salaf refers to a return to the time of the "ancestors" and the early period of Islam as a time of the epitome of Islamic society. Salafi is one who looks back and seeks to return to that idyllic time, hence all the proclamations about recreating the Caliphates. This looking back is so basic to contemporary fundamentalist Islam that an introduction to the early Islamic experience, as a historical basis, is essential if SOF hope to succeed in operational and training missions in the contemporary Islamic world.

The purpose is to provide a glimpse of how contemporary fundamentalist Islam looks back to an imagined ideal society. The arguments about identity and legitimacy begin in this early period and have continued more or less unabated into the contemporary era. The complexities and rivalries of Islam in its formative years are important for several reasons. The special place that the early years of Islam holds in salafi and fundamentalist thought-the idea 
that there was a more perfect time in which the umma or Islamic community was united-makes at least a rudimentary understanding absolute for those working or operating in the Muslim world. Second, those lacking at least a basic knowledge of the period risk being viewed as a "well-meaning but

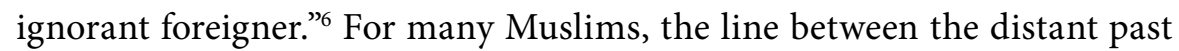
and the present is obscure to nonexistent and the inability to demonstrate at least a minimal familiarity with it is a real handicap-it is a credibility issue pure and simple.

The snapshot provides a view of an Islamic community that is anything but united; in fact, the community is defined by internal conflict. From the beginning, the story of the Prophet's travails in confronting those that opposed the political, economic, and social implications of Islam create a picture of a community of believers continually in conflict-a period in which political and economic power and social influence used the ideological rhetoric of Islam to legitimize their ambitions. In the Classical Age of Islam, Marshall Hodgson points out that during the period (632-680) from Abu Bakr to Mu'awiya I, "the character of the state and its durability were still in question." Finally, chapter one outlines an Islamic world that from the beginning was a highly heterogeneous community riven by political, economic, social, cultural, and sectarian conflicts, all of which Islam overlaid. Understanding Islamic development and the sources of contemporary conflict can provide useful indicators about political and religious predispositions. Thus, the contemporary conflicts in the Muslim world reflect not so much a clash of civilizations-Islam against the West-but rather a continuing internal struggle for dominance in which the West is viewed as an interloper, meddling in multi-faceted, age-old conflicts.

The second chapter introduces the shifting regional perspectives on U.S. policy. It provides an overview of the problematic development of U.S. policy in the Muslim world. Washington spends billions on public diplomacy and winning hearts and minds with little or no apparent return on the investment. Muslims hear one official message from Washington and see another on al-Jazeera, al-Arabiya and other regional media outlets when they cover Syria, Iraq, Afghanistan, and the Palestinian territories. This is a critical message for SOF personnel who are charged with both operational and training missions in the region. The idea that the United States can explain its good intentions in such a way that it will be acceptable in the Islamic world is problematic. In fact, polling in the Muslim world reflects just the opposite. ${ }^{8}$ 
Depending on the exact circumstances, shared interests make differences tolerable, but little more even with our closest allies.

How did many Muslim's perception of the U.S. devolve to the point where U.S. policy is now seen to be almost uniformly in a negative light from the Muslim street, or to frame it slightly different from a politicized perspective, 'to be on the wrong side of ideology?' The second chapter focuses on the post-World War II era and a fundamental understanding of the relationship between secular Arab nationalism (once viewed as the wave of the future in the region), U.S. policy, and the utility of conservative Islam. ${ }^{9}$ The discussion then moves to 1979-the year of crisis and decade of transition, from 1979 to 1990, marked a watershed in the U.S. relations with the Muslim world while the end of the Cold War changed Washington's global role. This decade, coupled with the experience of 11 September 2001, created the conditions under which the U.S. went from assiduously attempting to avoid large military involvement to a level of intervention that would have been unthinkable prior to 1990. This section provides a framework for understanding U.S. foreign policy focusing not on U.S. intentions, but rather on the results of those policies.

During the Cold War, the U.S. was a useful ally for conservative regimes and Sunni Islamists. In effect, Washington was on the right side of ideology, generally providing support that furthered conservative Islamist goals. After 1990, the U.S. emerged as the primary outside power playing a prominent role in the region. The second Gulf War (1990-1991) and the presence of U.S. forces accelerated resentment. ${ }^{10}$ Policies that pushed Western political, economic, and social ideas clashed with those who believed that "social virtue ... could come only from a restoration of the true Islamic doctrine of man." ${ }^{11}$ As Hasan al-Banna, the founder of the Muslim Brotherhood, put it: "the social principles" of the West converted man into an "instrument," destroying his humanity. Many Muslims today share this view..$^{12}$ One evil-godless Communism - disappeared and another-godless secularism-symbolized by the West took its place. The West found itself transformed from being an ally-albeit an awkward one-of Islam confronting godless Communismthe right side of ideology - to a symbol of political, economic, and social oppression-the wrong side of ideology.

The third chapter discusses the complex environment of conflicting political, economic, and social milieu with Islam as an ideological overlay. Muslims are little different from other political, religious, and cultural 
groups with respect to the utility of religion as ideology. They use religious language and selective theology in an attempt to create legitimacy for temporal objectives. Most monotheistic fundamentalists, no matter what their particular confessional proclivity, focus on literal interpretations of scripture to parse the texts in order to create a theological or ideological justification for political and social structures or in some cases plans of action. When one asks what Christians or Muslims believe, there are a plethora of answers that reflect the point of view and sociocultural prejudices of the one providing the answer. However, when religion is viewed as an ideological structure that overlays a particular set of political, economic, and social realities, then it is easier to see belief as a legitimizing construct that makes it a convenient and effective motivational catalyst and rationalization for action-any action. To understand a given situation, does one focus on religion and theology or on the underlying environmental reality that drives the strategic context?

Terror, in a more unemotional context as a tool, is an important part of this discussion. It is certainly not unique to Islamic societies. To paraphrase Clausewitz, terror "is a continuation of politik by other means." Terror is a tool used to achieve political, diplomatic, and at times economic objectives, and in the Islamic world, there is a debate as to whether the tool is sanctioned by theology or forbidden. It is the same debate that occurs in multiple forms in every society about the conduct of war-do the ends justify the means? Was Sir Arthur 'Bomber' Harris-because of his preference for area bombing instead of precision bombing of Germany in World War II-a terrorist; a misguided, failed strategist; or both? Is Russia a supporter of state terrorism because it allegedly provided Russian separatists with sophisticated surface-to-air missiles they apparently used to down a civilian airliner? During the American Revolution, did loyalist and rebel strikes and counterstrikes against the opposition's civilian population constitute terrorism? Do intentions actually matter, or is it the perceived results? This argument is a never-ending circle that largely depends on perspective.

This monograph rejects the simplistic notion of terrorism as a nihilistic manifestation of aspects of Islam or as an inherent part of Islamic culture. The author also rejects the idea that terror is Western in origin and a manifestation of Western influence within the Islamic community. As repugnant as Westerners and others may find it, terrorism is in simplistic terms, an ancient tool used as a tactical weapon to achieve policy goals. The political goals of those using terror as a policy tactic may not pass a reasonability test, 
but confusing the tool with an entire political and social system constitutes a colossal blunder.

The West and the United States are embroiled in one of the periodic eruptions that grip all societies-in this case the Muslim world. This political, economic, and cultural conflict over the nature of governance in the Muslim world shows no sign of abating. Islam represents the ideological engine legitimizing another period of significant political, economic, and social ferment of this period. The intent of this study is to provide the reader with different views of Islam that on the one hand step back to gain a better perspective on its heterogeneous character, and on the other to concentrate on key aspects of Islam as ideology in a fractured geopolitical and cultural environment. 



\section{Islam: Diversity of Politics and Faith}

eneralizations applied to a global religion espoused by billions of

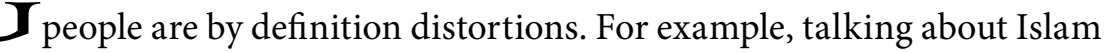
or Christianity in aggregate is impossible. In fact, the vitality and global spread of both is in large part a result of their adaptability to different social and cultural environments. Islam in particular tends to take on the local political, economic, social, and cultural colorings of the immediate environment. Even when the theology is ostensibly the same, the application and manifestation depends largely on the local environment. It is a strength for those who use it as a local or regional ideological motivator and find it highly adaptable to specific environments whether in Detroit, Marseilles, Tunis, Tehran, New Delhi, or Jakarta. It is a weakness for those who propagate it as a universal authoritarian creed because Islam is not a one-size-fits-all religion, even within the context of its major sects. This has been the Islamic reality from the beginning. ${ }^{13}$

For the last decade, there have been innumerable attempts to explain Islam in terms of the events of $9 / 11$ or through the views espoused by various Islamist groups. President George W. Bush explained on 20 September 2001 that al-Qaeda was a fringe group with "thousands of these terrorists in more than 60 countries" whose "goal is remaking the world and imposing its radical beliefs on people everywhere," and that they attacked the U.S. because, "They hate our freedoms: our freedom of religion, our freedom of speech, our freedom to vote and assemble and disagree with each other." This was an effective presidential rallying narrative for the U.S. public at large but did little to explain the complexities driving the situation within the broader Islamic community. ${ }^{14}$

What was required then and is still required now is an in-depth understanding of the context, particularly with regard to Islamic fundamentalists and radical violent extremists. What is it to be an Islamic fundamentalista salafi, one who seeks to recapture an earlier ideal Islamic society, and a radical Islamic extremist espousing the idea of a global Caliphate? What is the model? Did Islam ever exist in a unified perfect state, or is this an "imagined community" ${ }^{15}$ This idea of an ideal Islamic past, the past that devout fundamentalists as well as radical extremists see as the embodiment 
of the pure Islamic society, is just that-an idea-because it never really existed, but as an image it is very much alive. Understanding the image and the reality is very much a part of the basic skill set required to operate in the contemporary Muslim world. An introduction to the divisions and conflicts of early Islam is a fundamental building block. The political and cultural context of the past mirrors a present in which religion and theology become the ideological underpinning to far more worldly ambitions.

\section{Tawhid, Diversity, and Interests}

Tawhid (unity) is the most fundamental of the tenets of Islam-it is the oneness of God transcendent and unique; a basic tenet of the ideal Islamic community. Various Muslim groups have different doctrinal beliefs about how tawhid is applied. Fundamentally, it is the revolutionary ideological concept coupled to practical political policies that enabled Muhammad to impose unity on Arabia in the 7th century. Christianity and Judaism both existed in Arabia before the revelation to the Prophet, but the practical political aspects and discipline of Muhammad's approach were missing. As one Sunni fundamentalist thinker put it, "Tawhid is that which gives Islamic civilization its identity, which binds all its constituents together and thus makes them an integral, organic body which we call civilization." ${ }^{16}$ However, faith and theology rarely displace political reality. Ideology may have its moment, but it is inevitably superseded by the stress of conflicting interests. Factionalism had always been an issue in the Islamic community, but following the unexpected death of the Prophet in 632 C.E., it split the community.

Muhammad's (570-632 C.E.) role as the Prophet and Messenger notwithstanding, he was the consummate politician. His presence muted frictions within the Islamic leadership between those that had followed him to Medina in exile, driven from Mecca by the Qurayshi ruling families who he had magnanimously embraced following his triumph in 630 . Those who had suffered at the hands of the Quraysh and the new converts in Medina resented their continued prominence. ${ }^{17}$ Muhammad's death also brought a broader set of issues to the fore. Through marriage and other means, Muhammad had sealed alliances with the key tribal and clan groups of Arabia. For many of the tribal leaders, the alliance was personal, with Muhammad as opposed to an ideological commitment to a new order and the Prophet's successors. When the Prophet died, the Muslim community began to fracture. ${ }^{18}$ 
The leadership split over the question of whether Ali, the Prophet's sonin-law and cousin, should succeed him in a patrilineal line, or select a new leader. Abu Bakr al-Siddiq (573-634), the Prophet's father-in-law, became the first of the Rashiduun Caliphs. Sunnis argue that the selection was unanimous while the Shi'a reject the legitimacy of Caliphs Abu Bakr, Omar, and Uthman, arguing that Ali ibn Abi Talib (Ali) was the true successor chosen by the Prophet. This controversy immediately upon Muhammad's death nurtured seeds of fundamental preexisting discord in the Muslim community. ${ }^{19}$

In addition to the smoldering discontent associated with the selection of Abu Bakr as the first Caliph, many of those tribes that had viewed their ties to Islam in terms a personal relationship with the Prophet attempted to chart courses independent of the Caliph. Some repudiated Islam; others accepted Islam but repudiated the payment of the zakat to the authorities in Mecca; and still, others resenting the influence of the Quraysh offered their own alternate candidates for rule. In the year following Muhammad's death, Abu Bakr and his commanders fought a series of successful campaigns, the War of the Ridda (apostasy), to maintain unity and control of the umma from Medina. These early disputes were a harbinger of trouble to come.

The internal conflicts are even more apparent when one considers that despite the success of the Muslim conquests under Abu Bakr and his successor, Omar ibn al-Khattab (581-644), of the Rashiduun Caliphs (the first four), only Abu Bakr would die a natural death. The other Caliphs were all assassinated. In the first 50 years following the death of Muhammad, the Muslim community was irrevocably divided into conflicting camps that far exceeded in complexity the conventional views of Sunni and Shi'a divide. ${ }^{20}$ Were these early conflicts over religion and theology, or were they about political and economic power and social and cultural authority?

The struggles among the leadership of the early community for control represented only a subset of the divisions that were emerging. The factions themselves fractured. The Sunnis split into camps, some based on theological differences, but most based on opposition or support for the ruling Umayyad order. Umayyad policies on conversion, taxation, and other issues alienated many in the Orthodox community. The Shi'a, who began as a faction within the Islamic community, were emerging as a separate political party with their own distinctive theologically based ideology. Shi'ism represented a permanent division that has only become more pronounced over time. 
The Kharijites represented an even more fractured and divided group. Although small and persecuted, they claimed they were the only true Muslims and violently resisted suppression by Sunnis or Shi'a. The Kharijites evolved into a series of groups; "each group was at once a terrorist band and a fanatical religious sect." Descriptions of Kharijite bands resonate to some extent with similar descriptions of contemporary violent jihadist groups: "These Khariji bands were most likely formed by uprooted individuals looking for communal affiliation through sectarian movements." Theology varied among the Kharijite groups; thus, it was opposition to the ruling political structure or in some cases multiple structures that became the primary shared characteristic. They were politically dominant in many more remote areas-Oman, the Hadramut, Yemen, and in enclaves in North Africa and even after they were crushed as a political organization, Kharijite opposition went underground. ${ }^{21}$ Over time, Muslim divisions would only become more pronounced and more political. ${ }^{22}$

Among contemporary fundamentalists, it is this period of Islamic development that is presented as the ideal-a time of unity of belief and the community. It is an imagined past, but an imagined past that many Muslims today set forth as the ideal to be sought and achieved. In fact, Salafi beliefs about the age of the Prophet and the Rashiduun Caliphs being a time of purity and unity perpetuate an interpretation of the period that diverges from reality; their pronouncements must be understood in terms of the difference between an imagined ideal and a much more complex reality.

\section{The Umayyads and the Rise of Sectarianism}

Between 661 and 749, Islam had the superficial appearance of being monolithic. In a second great Muslim civil war, the Umayyads in Damascus used Yemeni tribes that had migrated to Syria to crush their opposition. As the umma fractured for the second time in 30 years, the Umayyads imposed iron-fisted centralization to maintain control. ${ }^{23}$ It also served as the model for the consolidation of conquests. They took the territorial gains of the four Rashiduun Caliphs and expanded them into the greatest of the Muslim empires. Umayyad conquests extended the borders of the Caliphate to India in the East and Spain in the West. Unlike the tribal wars of the initial conquest, these were planned imperial wars. ${ }^{24}$ Expansion was so rapid and far reaching that control dictated a contradictory system that combined 
a centralized Arab Caliphate with regional governors whose autonomy increased with distance from Damascus.

This was a stunning achievement, but success created problems. Revolts against Umayyad rule were constant. As a result, Umayyad policies tended to be draconian when dealing with unrest and often created even more resistance. Both the Umayyad's and their opposition used Islamic rhetoric as ideological justification for their policies. The resistance to their rule was often couched in religious terms but at root it was political, economic, and social. Political in the sense that the rapid conquest did not totally end resistance from tribal groups and local rulers who resented Umayyad policies. ${ }^{25}$ For example, in places like Oman, resistance to Umayyad rule at some level continued almost unabated even after the major population centers came under Damascus' control. ${ }^{26}$

Economically, the Umayyads developed a hierarchy among Muslim converts. Muslim authorities, particular the Umayyads, did not encourage conversion because people of the book-Jews, Christians, and some cases Zoroastrians-were obligated to pay the jizya. The jizya was a tax based on wealth and income that Muslim authorities levied on non-Muslims. It was a significant source of revenue for both local Umayyad governors and Damascus. Over time the increase in conversions began to threaten the Umayyads' revenue stream. ${ }^{27}$

Socially, Umayyad insistence on the predominance of Arabs, a clear minority in the empire, created deep-seated resentment of their rule. The Umayyads introduced a tiered system for Muslims differentiating between Arab and non-Arab Muslims (mawali). Some were accorded the full rights of the umma including an exemption from taxes like the jizya and some new converts continued to be subjected to taxes usually reserved for non-Muslims. In addition, Arab Muslims often paid reduced tax rates for property and commerce while non-Arab converts, or mawali Muslims, were required to pay in full.

In particular, the mawali of the garrison towns in the new empire-the soldiers, administrators, and merchants upon whom political control and economic prosperity rested-demanded equal treatment. When coupled with the persecution of Shi'a and other Muslim factions, Damascus found that it had to increasingly rely on coercion to maintain control. As a result, Umar II (717-720) instituted a new series of policies that recognized the equality of Muslims within the Umayyad framework. It represented a pragmatic 
maneuver to transform the empire from one that was Arab into a Muslim empire. $^{28}$

There were other aspects of Umayyad culture that contributed to its growing opposition. They took on the trappings of an empire, minting coins and building edifices like the Dome of the Rock in Jerusalem and new mosques in Damascus and Medina that symbolized their power. Umayyad rule represented a shift from the personalized rule of the Rashiduun period to the creation of a state bureaucracy that was self-perpetuating based on Byzantine and Sassanian administrative and political models. ${ }^{29}$ The Umayyads also promoted the idea that in addition to their status of imperial rulers with all the trappings of ceremony and court of the Sassanians and Byzantines, they were appointed by God and endowed with the religious authority of the Prophet. ${ }^{30}$

The combination of imperial extravagance, administrative practices, religious pretentions, and mawali reforms undermined the Umayyads with the Sunni religious authorities as well. The clergy remained attached to the institution of the Caliphate but rejected the now universal claims of authority on the part of Umayyads who had become temporal rulers. ${ }^{31}$ This compounded another problem plaguing the Umayyads in their relationship with the ulema or Islamic scholars of fiqh (jurisprudence) whose rulings delineate sharia law. The empire was more non-Muslim than Muslim, and the administration reflected that fact. Even at the end of the Umayyad period, most were still non-Muslim. As Kennedy notes, "Muslims still formed a very small proportion of the population of the Near East." 32 As a result, the Umayyad administration was in many respects secular creating issues of religious legitimacy. Nevertheless, it was the Umayyad political compromises or flexibility that enabled Arab culture and language to become that of the ruling class and its retainers and Islam to become the religion of the ruling class. ${ }^{33}$

Until 740, competent leadership hid most of these underlying problems. Large numbers of the non-Arab Muslim converts had long been restive about discriminatory policies that favored the more established Arab Muslims. ${ }^{34}$ Umar II's reforms had changed some of these policies, but their application had been less than universal, and his assassination had put a damper on their more rigorous application. The attempt to reform had alienated many in the Arab hierarchy who continued to view themselves as more Muslim than the new converts. The Sunni clergy had become increasingly uncomfortable with the trappings of empire and the religious implications of Umayyad 
policies - most notably assertion of the Caliph as God's appointed in all matters temporal and religious. These were not the only internal problems. In the hinterland of the empire, governors and regional military commanders faced increasingly restive and fractious populations. ${ }^{35}$

In Syria, the fundamental fissures that had existed from the beginning resurfaced. Within the ruling elite, there were two primary factions-the Yamanis and the Qays. The Yamanis were tribes originally from the Nejd Desert and southern Arabia (Yemen) who had been the backbone of the armies that conquered Syria. The Qays were indigenous northern Arabs that had dominated much of the Umayyad administration. During his 19-year rule, Caliph Hisham (reign 724-743) had stayed above the fray and manipulated the competing parties. He bequeathed to his successors a stable empire at peace.

His successor, Walid II, lacked Hisham's acumen for rule. Walid's incompetence increased the factional struggles, brought a split in the Umayyad clan, and culminated in his assassination in 744. The next Caliph, Yazid III, initiated reforms, but died in 745. Conflicting claims to the throne resulted in the occupation of Damascus by Marwan ibn Muhammad, the governor of Armenia and Azerbaijan. He suppressed Yamani rebels and then moved to recoup the Umayyad position in Mesopotamia and put down multiple revolts. The empire was too fractured for even an experienced administrator and commander like Marwan to control the situation. ${ }^{36}$

In Persia, Oman, North Africa, Spain, Mesopotamia, and other regions, local political, economic, and social grievances about rule from or in the name of Damascus found expression in the ideological message of Shi'a, Khariji, Sufi, and dissident Sunni groups. What was good for the Umayyad state was not necessarily good for Muslims with different ideas about their interests. Even under the rule of the greatest of Muslim empires, in the century after the death of the Prophet the community was fractured. There were powerful undercurrents of opposition based on political, economic, social, cultural, and religious differences that required either suppression or accommodation, and these undercurrents would ultimately undermine the Umayyads. Rival political groups and interpretations of Islam constantly challenged what existed in the way of centralized power. To discuss Islam in terms of what Damascus called legitimate orthodoxy was different from how it was viewed by many in the community because although over laid by Islam, the interests and cultures in different parts of the empire were in 
fact different. It would be those different interests and cultural conflicts that would lead to one of the more spectacular collapses in history. ${ }^{37}$

\section{The Abbasids and the Fracture of the Umayyad State}

Since 680 , the Shi'a had not played any substantial open role in politics. They continued to have a strong underground presence, particularly around the old garrison town of Kufa in southern Iraq. Umayyad hostility created an environment in which the Shi'a were constantly plotting against the government between 730 and 740 . This conflict was led by Zayd ibn Ali, the fifth Imam. Zayd was the grandson of Hussein who was martyred by the Umayyads at Karbala 60 years before, and the great grandson of Ali ibn Abi Talib, the fourth Rashiduun who was the first Imam to the Shi'a. Centered on Kufa, Zayd's revolt had significant ramifications.

When confronted by overwhelming Umayyad forces, Zayd refused to surrender. ${ }^{38}$ Zayd is alleged to have recited a poem that included the lines, "Disgraceful life or honorable death both are bitter morsels. But if one of them must be chosen, my choice is honorable death." ${ }^{39}$ His resistance to Umayyad control set in motion a series of events that would destroy the Umayyad Empire. Additionally, within the Shi'a community, an entire new sect of Shi'ism, the Zaydis, would emerge. Known as Fivers because Zayd was the fifth Imam, they believed Zayd was the last of the line of direct Imams from Ali ibn Abi Talib. Communities of Zaydis would spring up in Mesopotamia, Persia, and eventually in Yemen. ${ }^{40}$

Particularly in Mesopotamia, there was a growing conviction that only the restoration of the rule by a descendant of the Prophet could restore the unity of the umma combined with increasing resentment of "Syrian rule." This was not only a Shi'a point of view but also shared by many Sunnis. There was a problem - what constituted the "family of the Prophet" lay in the eye of the beholder. While the Shi'a, both Ismaili and Jafari, accepted only direct descendants of Ali ibn Abi Talib, others accepted a more open interpretation that included the Prophet's paternal uncle, Abbas. The leader of the Abbasid clan, Ibrahim, managed to overthrow the Umayyads not through a broadly based movement against the regime in Damascus but rather by obtaining the allegiance of a narrow Muslim group, the Khorasanis.

Khorasan, a former province of the Sassanian Empire, retained its identity following the Muslim conquest. Khorasani soldiers from the eastern 
edge of the empire provided the backbone of the military force that from 747 to 750 decisively defeated the Umayyad armies and opened the door to the annihilation of the Damascus regime. The Abbasids also co-opted the Yamani tribes displaced by the Qays in Syria. It also included groups of Shi'a and Kharijites that believed that a new order would improve their political and economic position in society. ${ }^{41}$ When Abbasid forces reached Damascus, the Yamani opposition to the ruling Qays faction opened the gates. Completely defeated, the campaign focused on the annihilation of the Umayyad leadership. The entire leadership of the old ruling order was eliminated with the exception of Abd-al-Rahman, the grandson of Caliph Hisham. Abd-al-Rahman escaped by a circuitous route from Damascus to Muslim Spain and there began the process of reviving Umayyad fortunes. ${ }^{42}$ Eventually, the Umayyad Emirate and later Caliphate of Cordoba (756-1031) emerged. ${ }^{43}$

The same undercurrents of opposition that destroyed Umayyad rule now threatened the nascent Abbasid Caliphate. From its inception, the Abbasid Caliphate was significantly different in terms of rule and administration than that of the Umayyad. They had come to power supported by military forces whose powerbase lay far outside Arab Syria or Arabia. They were beholden to the Khorasanis. The geopolitical and socioeconomic realities of the Abbasid Caliphate forced a new paradigm for rule on the Caliphs. The triumph of the Abbasids moved the center of gravity of the new empire to the east. The Abbasids lost control of Spain, the Maghreb and parts of North Africa, and key Abbasid support came from the Khorasanis in the east. One of the first issues was the location of the capital which was moved from Damascus to Baghdad-a more central location. ${ }^{44}$

Next, the Abbasids began the process of consolidating their power. The Khorasanis and prominent clans among them were instrumental in the overthrow of the Umayyads and in creating a new ruling structure. In particular the Barmakids were key supporters of the first two Caliphs, Abu al-Abbas al-Saffan (reign 750-754) and Abu Jafar al-Mansur (reign 754-775). Khalid bin Barmak was a trusted vizier and his son, Yahya bin Khalid advised their successor, Caliph al-Mahdi (reign 775-786), and served as tutor to Caliph Harun al-Rashid (reign 786-809). The Barmakid family played a key role in Harun al-Rashid's rise to power. Nizam al-Mulk (1018-1092) the vizier of the Seljuk sultans in Baghdad, described them as first-rate administrators of Persian ancestry with the shrewdest of political instincts. ${ }^{45}$ The Barmakids' fall from 
power in 803 was the culmination of a period of decline in which internal political struggles increasingly undermined their influence. The Barmakids are inseparable from the Golden Age of the Abbasid Caliphate (763-809) and form a broader discussion of how the Caliphate actually functioned. ${ }^{46}$

The Barmakids' role in Baghdad illuminates a key difference between Abbasid and Umayyad rule. Umayyad rule had been concentrated within the clan. Under competent Umayyad leadership, the cohesion provided a huge advantage in administering the empire-under poor leadership it was disastrous. The Abbasids did not have that luxury. They were far more dependent on political power centers that resided outside the immediate Abbasid clan and entourage. Like the Umayyads, they faced many of the same political challenges. The Shi'a and Kharijites felt betrayed by the Abbasid 'revolution' and almost immediately faced a series of revolts. The Abbasids needed political and military support and sacrificed some of their autonomy and power to co-opt supporters. With rare exceptions, Baghdad became subject to outside influences. In his struggle for power against his brother, Caliph Abu Jafar ibn Harun al-Mamun (reign 813-833) would turn to another clan, the Tahirids for support. Because of their role in securing the throne for al-Mamun, the Tahirids became indispensable to Abbasid rule in Baghdad and established a dynasty in Khorasan (821-873). Their support for the Caliphate restored Abbasid fortunes in the West to the end of the 9th century. ${ }^{47}$

Al-Mamun introduced another divisive element into Islam. Increasingly, Islam had found itself in ideological competition with Christian Byzantium. The Byzantines had incorporated classical philosophy into their arguments about theology. Caliph al-Mamun and many Muslim thinkers of the period accepted philosophical inquiry and reason as a "neutral science, which provided valuable aids for clarifying theological and religious problems." AlMamun accepted the view of the mutazili that the Quran was created; this meant that it was subject to interpretation by the Caliph. The mutazilah was a school of Islamic thought and practice that based its interpretations of law on reason and logic derived primarily from classical Greek philosophy. To force the traditional ulema to accept this interpretation of Islamic law, alMamun instituted the mihna, or inquisition, to compel the ulema to accept this theological innovation.

This was not a trivial matter. Traditional Islamic theology held that the Quran was not created but of the same essence as God. Most acquiesced but Ahmad ibn Hanbal refused and became the head of those in the ulema that 
rejected the philosophical approach. They held that the Caliph was "merely the executor of the Islamic community and the source of its beliefs." This situation brought another ideological schism between combined religious and temporal authority desired by the Caliph and his political and religious opponents who sought to limit his power by sharply circumscribing his religious power. ${ }^{48}$ Despite the theological controversy, the real issue at stake was not religion but rather politics and power. Given the nature of the society and culture, the competing factions expressed their struggle for earthly political power in theological terms.

The struggle between the Caliph's new mutazili elite and their political and theological opposition resulted in a decision by al-Mamun's successor, Caliph al-Mutassim, to relocate the capital to Samarra north of Baghdad. The socioeconomic elite of Samarra had become identified as mutazili and sought to displace Baghdad as the center of political power in the empire. In addition to his political innovations, al-Mamun had changed the security structure of the state at the expense of the old abna elite in Baghdad..$^{49}$ Seeking a reliable military force loyal to the Caliphate, al-Mamun had introduced a military structure based on a Ghulam, or slave system. Composed of Turkish slave soldiers, these troops were more reliable and loyal only to the Caliph. The move to Samarra enabled the Caliph to reward his new military with land and to separate them from the anti-caliphal influences in Baghdad. ${ }^{50}$

The political nature of the conflicts was further illustrated by the rise of Caliph Mutawakkil (reign 847-861). Mutawakkil wanted to rid himself of the Samarran elite that had dominated the administration since the reign of Mutassim. The close association of the Samarrans with the mutazili made reconciliation with the religious traditionalists a desirable political move. Perhaps, Mutawakkil's personal beliefs reflected traditionalist views; whether or not this was the case, the politics of situation dictated that Mutawakkil break the power of the Samarrans, making a return to the traditionalist religious camp expedient.

With hopes of ensuring traditionalist support, the Caliph launched a campaign against the Shi'a and the dhimmi. The dhimmi refers to "people of the book," i.e. Jews, Christians, and at times even Zoroastrians. Muttawakkil was now caught between the Samarrans, whose power he had just undermined, and the traditionalists in Baghdad, who sought to dominate the Caliphate as they had before the reign of al-Mamun. He toyed with the idea of transferring the seat of power to Damascus, but the political ghosts of 
the Umayyads prevented that. He ultimately attempted to found yet another new capital near Samarra; it was not a viable site. ${ }^{51}$ Mutawakkil's attempt to establish his independence created powerful enemies among the Turkish military cadres. In 861, they assassinated the Caliph. A period of anarchy ensued with the Turkish troops holding the political balance of power. In 870, the Caliphate was restored, but its political and military stability continued to be tenuous. The Samarrans and Baghdadis continued to vie for control and both would eventually succumb to the Seljuk Turks. The Caliphate as a symbol would endure until the Mongol deluge of 1258, but by the mid-10th century, the Caliph was little more than a figurehead. The Caliphate, or more accurately the empire, had fractured along political, cultural and sectarian lines. Divisions that had existed even during the height of the Caliphate now emerged to divide it and control it.

The fractured geopolitical and socioeconomic landscape of the region asserted its ascendency, and Islam reflected this diversity. Islam was defined in terms of specific geopolitical and cultural settings the granularity of which transcended any limited concepts of Sunni and Shi'a or even Kharijite. From this point forward, independent Caliphates, empires, and states would emerge and then eventually collapse throughout Islamic history-the surviving Umayyads in Spain, the Ismaili Shi'a in Fatimid Egypt, the Zaydi state in Yemen, the Ibadi state in Oman, just to name a few. Historical and contemporary movements with millenary dreams of recapturing or creating a Unitarian Islamic political or community structure based on the principle of tawhid are "imagining" a unified community that never actually existed. All Muslim communities hold to an "ideal" as a reflection of faith and belief that is invariably at odds with the political, economic, social, ideological, historical, and contemporary reality.

\section{Summary}

There are three important points to be gleaned from the brief overview of early Islam. First and foremost is a perspective on Islam focusing not on theological interpretations, but rather on Islam's extremely complex political, economic, social, and cultural diversity. When speaking in general terms about faith and theology, Muslims talk about the unity of the umma and the shared values and beliefs, but when it comes to the specifics (political, economic, social, and cultural)—chasms divide the community. This has 
been the situation from the very beginning-even the Prophet struggled against divisiveness and internal conflict. Upon his death, divisions emerged almost immediately.

Thus from the very beginning, the term "Muslim" explained little beyond a basic set of beliefs shared by the community. When one asks what specifically it means to be a Muslim, the answers from a Sunni, a Shi'a, or a Kharijite could be quite different. When taken to the next level, the Islamic World was even more divided with schools of Islamic law among the Sunnis, the rise of Sufism with its ascetic rituals, the three major branches of Shi'ismFivers, Seveners, and Twelvers, and the Kharijites who saw themselves as the only true Muslims.

This view of Islam and Muslims as extremely heterogeneous is often lost when discussions focus on terrorism and Islamic radicalism. The concept of tawhid, whether it is the oneness of God or of the community, is so central to Islamic self-perceptions that Muslims are often loathe to frankly discuss the divisions. Thus, the idea of the unity of Islam becomes the ideal that is often represented as the reality by Muslims themselves. In the West, this is picked up and Muslims ascribed to have a unity of belief and purpose that has never existed. This contributes to a lack of understanding of the real depths of Islamic diversity.

This chapter provides a brief overview of the political development of Islam-a practical concise look, not at over-simplified views held by many Westerners and Muslims alike. It is a snapshot of the political reality and diversity of Islamic development and a guidepost for a more detailed investigation. It also contains an advantage particularly to SOF personnel with operational and training missions in the Muslim world. Like most groups, including Westerners, many Muslims have only a vague and at times distorted understanding of their own historical context. This overview provides a template for understanding Islamic political development. It places a concise framework for evaluating the emphasis that many Muslims place on the umma and tawhid-an emphasis that often distorts the reality of Islamic development.

The third benefit is credibility. The success of SOF is often measured in terms of relationships established and bonds forged than in any other element. For Muslims, their particular view of the past, especially the early Islamic period, is critical to their contemporary world perspective and selfidentity. SOF personnel need to understand these issues that are important 
to Muslims. For some Westerners, the past is simply not that relevant, and lack of knowledge of it generally reflects that view; in the Muslim world, the distant past (1,500 years ago), as remembered or imagined, is very much a part of the present. A basic knowledge of the Islamic past is critical. It provides a prism for more sophisticated operational and analytical judgment and enhances personnel and institutional credibility with those that SOF seek to train and influence. SOF can be more credible and thus effective with Muslims if they understand the key periods and diverse paths and ideologies in Islamic history. A new dimension of credibility accrues to those whose resources include a reservoir of knowledge and an understanding of the diversity of the historical Islam, and can demonstrate a basic knowledge of Islamic political development. For those who cannot, they are handicapped and the goals of the mission are less likely to be met. 


\section{The United States and the Wrong Side of Ideology} rong in the title of this chapter refers not to a particular mistake or
set of miscalculations on the part of the West, but rather to a shift in Muslim perceptions about the West in general and the United States in particular. Miscalculations over the past decade about democracy and the utility of military force in stabilizing conflicts have certainly taken their toll. To some significant degree, the negative perceptions of the United States among Muslims has been predictable and likely unavoidable. SOF today have to recognize that many Muslims in the world where they will be operating feel that U.S. policies and military actions since $9 / 11$ have been misguided. It may be unspoken, but it is nevertheless an element that is always present.

How did the United States over a period of roughly 70 years progress from a limited role that was generally tolerated to becoming the most unpopular country in the Muslim world after Israel? The unpopularity of the U.S. government in most regions of the Islamic World is pervasive. For example, polls in 2010 indicated that 85 percent of Arabs viewed the U.S. unfavorably. ${ }^{52}$ Is it correct to argue that the more regional entanglements, the more unpopular Washington becomes, or is there something more to it? The United States has sacrificed lives and spent trillions of dollars in attempting to stabilize the region, and yet the region is increasingly unstable and the U.S. is more unpopular than ever. Whether deserved or not, it is important that SOF assigned to the Muslim world grasp the progression of U.S. policy in the region and a realistic perspective on how the U.S. is viewed.

There are many reasons for how U.S. policy is viewed by Muslims and how the U.S. views the Muslim world. They are not simplistic bromides about "a clash of civilizations" or views that equate Islam with the totalitarian regimes of Nazi Germany or Stalinist Russia. Those views have more to do with superficial Western-centric views of political and cultural exceptionalist superiority than they do with the actual historical context. For all of its good intentions, U.S. attempts to convince Muslims of the efficacy of its policies have failed because the situation has changed and the task of stepping outside the confines of Western-centric views is too complex. 
This discussion of the United States and Islam focuses on a political and cultural learning curve that has never been overcome. The issue of security and attacks on the homeland is a tactical security issue with critical political implications for any given U.S. administration. The most altruistic of U.S. policies has reflected preconceived notions about the superiority of Western liberal institutions and condescending attitude toward Muslim societies on issues of democracy, gender, and social morays that not only enflames multiple levels of Muslim society but also distorts Western perception what U.S. involvement can achieve and what is clearly impossible.

The intent here is not to focus on what should have happened, but rather to concentrate on what did happen and its implications. The argument is about developments in the Islamic world and how U.S. reactions to those developments shaped the contemporary environment. It was predictable, if not expected, that the only superpower would find itself hamstrung and in considerable fiscal distress after attempting to impose its political and social values on a part of the world that had never shared them. This is about examining U.S. policy from the points of view of a fractured Islamic world and making a realistic evaluation of what most probably could be expected to happen.

This chapter examines the evolution of U.S. policy in the Islamic world. There is a brief discussion of the limited post World War II experience and the formative process of preconceptions that still affect U.S. attitudes and policy. The second section discusses the emergence of new nation states that roughly followed the boundaries drawn by colonial occupiers. It also includes a discussion of the U.S. reaction to the various forms of nationalism that emerged after 1945. The Cold War confronted the U.S. with new policy dilemmas from Morocco to Indonesia. And, while nationalism in the Islamic world found expression in secular government, those governments tended to be 'non-aligned' in the East-West conflict and many were leftist in their leanings.

In Egypt, Gamal Abdul Nasser introduced Arab Socialism. In Indonesia, Sukarno advocated an Indonesian-style socialist system based on the principle of USDEK ${ }^{53}$ In Syria and Iraq, a new group gained traction, the Arab Socialist Ba'th Party, which advocated for Arab nationalism, Arab socialism, pan-Arabism, and anti-imperialism. The Ba'th found itself in competition with the Communists, the old notable classes, the Islamists, and the Nasserists. In India, with the second largest Muslim population in the world, 
Nehru embraced secularism, socialist economic policy, and non-alignment, including the recognition of Communist China. From a policy point of view, McCarthyism and the Red Scare and pervasive misconception of monolithic Communism created an environment where Western policy aligned with support for conservative traditional regimes and the leverage provided by Islam against socialism, Communism, non-alignment, and Soviet and Chinese influence. In effect, conservative Islam was an ally in the Cold War struggle against the Soviet Union.

The centerpiece for this chapter is the examination of two decades of change (1979 to 2001) that fundamentally reordered the position of the United States in the Muslim world. During this period, the U.S. moved from being tolerated, if not embraced, to becoming for some Muslims a symbol of imperialism, injustice, and oppression - the enemy of Islam. The discussion begins with the Iran hostage crisis of 1979-a year in which the imperatives of Cold War policies were realized. With the exception of Iran, the U.S. participated in empowering a new cadre of radical Islamist organizations and individuals while at the same time pursuing policies that would ultimately make the U.S. and the West the target of those very forces. This chapter takes the rise of radical Islam, the end of the Cold War, and the empowerment of non-state actors, and examines U.S. policy and perceptions as it struggled to cope with new constructs emerging in the Islamic world.

It also covers the last 10 years as the crisis of $9 / 11$ brought wholesale U.S. involvement from North Africa to Asia and an environment in which preconceived political and social ideas were often applied to the Islamic world with little appreciation for the fundamental differences. It was a period in which U.S. policy formulation was based more on ideology than on real politik. In terms of Islam, the U.S. found itself on the wrong side of ideology-assailed for well-intended policies that resulted in two wars that shook the confidence of traditional allies and strengthened the hand of regional opponents.

\section{The U.S. and Islam: The Pre-1945 Unknowns}

Relatively speaking, there was only limited interaction between the U.S. and Islamic states prior to the end of World War II. Interestingly enough, some of the interaction found its way into the 'heroic' narrative of the national experience. Since 2001, the interpretations of the Barbary Wars (1801-1815), 
fought by the United States and others against the piratical Ottoman vassal states of North Africa, have focused on Islam as the principle problem. As Frank Lambert states in The Barbary Wars: American Independence in the Atlantic World: "Regrettably, much of what we learn from recent works tells us more about the present than about the past." The Barbary Wars were about trade and about a weak fledgling nation attempting to protect its commercial interests that had been previously guaranteed by the most powerful navy in the world. The Barbary States were not the equivalent of "modern day terrorists" as some have argued. Thomas Jefferson viewed the conflict with the Barbary pirates as a "side-show" to the more important issue of Atlantic community trade. ${ }^{54}$

The Barbary Wars were not an ideological conflict with Islam although the language of the conflict tended to obscure the reality. As in the case of Tripoli's envoy, Sidi Hajj Abd-al-Rahman's statement:

It was written in their Koran, that all nations which had not acknowledged the Prophet were sinners, whom it was the right and duty of the faithful to plunder and enslave; and that every mussulman who was slain in this warfare was sure to go to paradise.

Of course, the envoy was willing to forgo the "right and the privilege" for the right payment. ${ }^{55}$ The Barbary Wars may have provided another lesson in foreign relations-Washington learned that whether the issue was regime change or militarily cowing to their opponents, long-term campaigns were too costly and produced only marginal success. ${ }^{56}$

American contact with Islamic societies was largely through trade and commerce. In the late 19th century, a reform movement emerged in American politics that called for a change in the role of government in society. The movement crossed party lines in the early 20th century producing the first progressive president, a Republican, Theodore Roosevelt and the second, a Democrat, Woodrow Wilson. Progressivism also promoted an exceptionalist American self-image. The idea held that American ideals were transferrable and if copied others would achieve economic success and democratic political stability. When coupled with the economic power and aggressive nationalism, progressivism reinforced the idea that the U.S. had an obligation to apply those principals.

Such an opportunity came in 1898 when the United States won the Spanish-American War and took possession of most of the Spanish empire, 


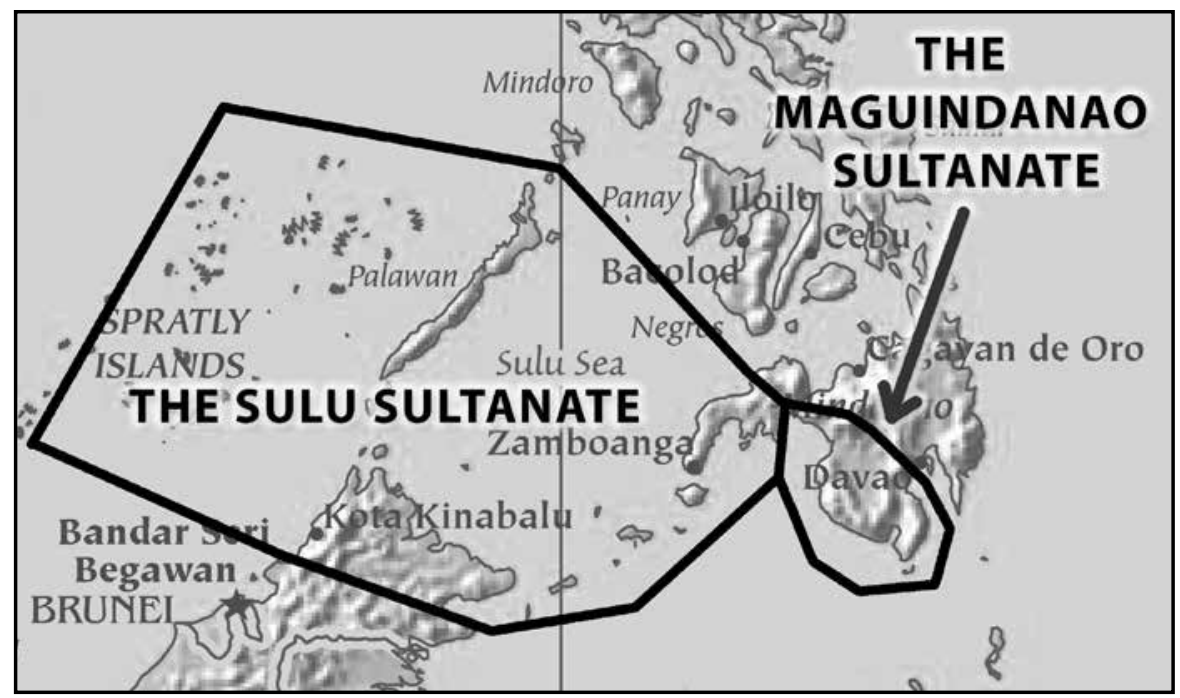

Figure 2. Map of the Sultanate of Sulu rule over the Philippines. Original Map Source: Central Intelligence Agency.

including the Philippine Islands. The situation in the Philippines was complicated. First, the indigenous independence movement expected to form the next independent government. Second, the islands were politically and culturally complex. The inhabitants of the southern islands were largely Muslim and their political status within the Spanish Empire was somewhat ambiguous. Their territories had constituted the Sultanate of Sulu founded by Sayyid Abu Bakr Abirin dated from the mid-15th century. They had never viewed themselves as part of the northern islands. The Muslims or Moros of Mindanao had fought against the Spanish-backed Catholics for centuries. The U.S. administration and army in the Philippines would find itself facing first a rebellion by supporters of the Philippine independence movement and by the indigenous Muslims of the southern Philippines who believed that they were entitled to their own independent state. The Moro rebellion was always more national than Islamic and continues to be so today. ${ }^{57}$

On 1 May 1898, Commodore George Dewey's Asiatic Squadron destroyed the Spanish fleet in the Philippines. Immediately, President William McKinley dispatched a hastily constituted expeditionary force under Major General Wesley Merritt to complete the conquest of the islands. President McKinley decided that the United States would take over the Philippines and placed the responsibility to administer the "benevolent assimilation" and to "win 
the confidence, respect, and affection of the inhabitants of the Philippines" on the U.S. Army. Merritt told his men that they were there:

... not as despoilers and oppressors, but simply as the instruments of a strong, free Government whose purposes are beneficent and which has declared itself in this war the champion of those oppressed by Spanish misrule.

Some took the message to heart while others treated the Filipinos with lawless disregard, contempt, arrogance, and "little concern for Filipino traditions and customs." 58

In June 1899, the First Philippine Republic declared war. By January 1900, U.S. forces had destroyed the revolutionary Filipino army. The apparent victory quickly degenerated into a bloody guerilla war. One exasperated U.S. captain expressed a lament that has been heard frequently in the last 100 years of American counter-insurgency wars:

One day we may be fighting with thousands of their people [and] the next day you can't find an enemy, they are all 'amigos.' They have hidden their rifles and may be working for you, for all you know. ${ }^{59}$

The breakdown of public order undermined the already tenuous hold of central authority on the outlying regions. Washington insisted that the U.S. Army get control of the situation and "win the confidence, respect, and admiration" of the Filipino people. ${ }^{60}$ By April 1902, the revolutionary insurgents had largely been suppressed, except in the south.

During the conflict with the First Philippine Republic, the U.S. Army had carefully avoided provoking an uprising in the largely Muslim south. The U.S. commanders were convinced that "a combination of patience, scrupulous regard for religious rights, and respectful treatment would win over the population." ${ }^{11}$ With regard to the Muslim population, the overriding U.S. policy thrust focused on preparing Muslims to participate as unified, relatively progressive minority in a new independent Philippine republic.

It was a naive intention, and events, of course, didn't work out that way. But colonial practices did have the effect of encouraging the development of a unified Philippine Muslim (or Bangsamoro) identity. ${ }^{62}$ 
The U.S. involvement also provided a lingua franca-English-for Muslim separatists that has persisted to this day. "English has provided a neutral political language." 63

The conflict transformed the Moro war into a "colorful romanticized" struggle and, according to Brian Linn, "made them [the Moros] as archaic and colorful as the army's former opponents, the American Indians." Everything about the Moros and the conflict against an exotically clad, fierce, courageous adversary led by devout Muslim chieftains captured the American imagination.

Indeed, to the Progressive Era American still coming to terms with the end of their own Wild West, Moroland resonated with the richness, mystery, and danger both of the last continental frontier and the yet unexploited Pacific. ${ }^{64}$

It provided the new Pacific army with a tie to the American frontier struggle. Romanticism aside, progressive American policy saw the Moros as "savages, who needed to be civilized." Everything about them constituted an affront to what American progressives considered acceptable:

Their slavery, piracy, polygamy, autocratic clan government, blood feuds, endemic warfare, and the ritual of juramentado-in which a devotee sought to kill as many Christians as possible-were all self-evident barbarities to the new colonial administration. ${ }^{65}$

For centuries, the Moros resisted attempts by the Spanish and their Christian Filipino allies to subjugate or annihilate them. Their fight against the U.S. Army was not one of a unified political or military organization but rather the struggle of a fragmented tribal society. As one American officer put it, "the Moros stand in the way of our destiny, and we cannot permit that." Islam was the only shared ideology but "jihad was vitiated by religious divisions." ${ }^{\prime 6}$ Military policies swung from the conciliatory policies of Captain John J. Pershing that emphasized minimum casualties and patience to the aggressive confrontational approach of Major General Leonard Wood whose assault on Bud Dajo on Jolo Island resulted in the deaths of numerous civilians.

Pershing pursued a policy that kept U.S. and Moro casualties to an absolute minimum because he recognized that at some point there would have to be a political compromise. Pershing's policies, including building 
mosques and improving communications and roads, were largely successful; by 1913, the U.S. regulars could be withdrawn from the pacified Moro areas. ${ }^{67}$ Although the Muslim areas of the Philippines had been transferred to civilian authority, frictions, resentment, and conflict smoldered just under the surface. From a Muslim perspective, Washington had sided with their Christian enemies in Manila who could have never have subdued the Moros had it not been for the U.S. Army.

The Philippine and Moro wars were shortly dwarfed by World War I. The aftermath of the war and the ideological commitment by President Woodrow Wilson to the progressive ideals of self-determination for colonial peoples and democracy brought a short-lived involvement in the disposition of the various parts of the former Ottoman Empire. At the Paris Peace Conference of 1919, competing factions claimed their own piece of the Ottoman Empire. Wilson, who attended in person, insisted that a commission be formed to investigate the issues of the region and to determine what the most reasonable and fair disposition should be.

The result was the King-Crane Commission. Henry C. King and Charles $\mathrm{R}$. Crane toured the region and discussed political preferences with various leaders. They reported back to Wilson that leaders in the former Ottoman territories preferred independence as a first option and a mandate or protectorate by the United States as the second. If not the United States, then they preferred the British to the French. Not only were the British and French opposed to Wilson's idealist plans, but also the Republican Congress was in no mood to support either Wilson or an expensive military occupation in the Middle East. ${ }^{68}$ There would be no official U.S. role in the Middle East for 20 years.

Politically, Washington had only a limited presence in the region, but in the 1930s, commercial interests would change the situation. In Saudi Arabia, the Great Depression had severely reduced revenues from the annual Hajj and the possibility that oil might compensate for the shortfall. In May 1933, assisted by St. John Philby, a former British Indian Service official, a consortium of American oil companies concluded an agreement with King Abd-alAziz al-Saud (Ibn Saud) for an oil concession. Four years later exploration teams brought in Dammam No. 7, the first commercially viable oil well in Saudi Arabia and the oil venture that eventually became the ArabianAmerican Oil Company, linking the American oil industry to a conservative Muslim state and society. ${ }^{69}$ The British sought to limit the U.S. role. In 
1939, the coming of the Second World War began the process that changed Washington's role in the Muslim world. U.S. influence from Indonesia to Morocco had increased enormously as Britain and France lost their grip on their former colonies.

By the end of the war, it appeared the United States would be in position to make good on its efforts in support of national self-determination that their allies had stymied in 1919. President Franklin Roosevelt believed that the failure to implement "self-determination" had been one of the primary causes of the rise of Germany and of the Second World War. He refused to make any commitments pre-1945. He rejected any hint of the secret agreements like Sikes-Picot that came to light in 1918 and believed that post-war plebiscites were the best means of insuring national aspirations. ${ }^{70}$ At least in principle, the United States opposed both the resurrection and the continuation of colonial rule and this included the Islamic world.

\section{The Cold War and the Right Side of Ideology}

There has been much debate about political developments in the Middle East between 1945 and 1979. Globally, U.S. policy was driven at times by a view of Communism as a monolithic threat. In 1945, the United States found itself in reasonably good stead with emerging Muslim states. From 1945 to 1953, the U.S. had at least in theory supported the elimination of colonialism around the global. ${ }^{71}$ In the Islamic world, Washington supported Indonesian, Malaysian, Indian, Pakistani, Iraqi, Syrian, Lebanese, Egyptian, Sudanese, Tunisian, and Moroccan independence. It also resisted British attempts to enlist U.S. support in toppling the governments of Iran and Egypt. While support for and recognition of Israel created problems, Great Britain, because of its footprint in the region, was the primary focus of Muslim frustrations. Issues with the U.S. were masked by the British presence. In addition, American attitudes, at least early on, were different.

In late 1952, President-Elect Dwight Eisenhower expressed his reservations about the British alliance and potential impact on the developing world. His view of Churchill is particularly telling. The President stated that Churchill was, "trying to relive the days of World War II ... sitting on some rather Olympian platform with respect to the rest of the world, and directing world affairs" with another American president. Eisenhower was blunt, saying: 
Winston does not by any means propose to resort to power politics and to disregard legitimate aspirations among weaker peoples ... But, he does take the rather old-fashioned, paternalistic, approach ... [that] other nations should recognize the wisdom of our suggestions, and follow them. ${ }^{72}$

The president believed that "persuasion and example" and a "patient negotiation, understanding and equality of treatment" approach would succeed. ${ }^{73}$

During President Eisenhower's Administration (1953-1961), Eisenhower feared what he called the "momentary independence." He saw a rush to independence as a threat to stability that would open the door to potential Communist takeovers. Washington clearly supported an "orderly" transition to full independence and an appropriate expression of constructive nationalism for developing nations. ${ }^{74}$ To no one's surprise, in early 1953 , Eisenhower and Secretary of State Dulles declared that the priorities for U.S. policy in the Middle East would be containment of the Soviet Union and Communist influence through economic development, covert assistance to pro-Western elements, and, if necessary, military assistance. A solution to the Anglo-Egyptian impasse over British bases in the Suez Canal Zone was first on the agenda. Next came the "critical" problem of Iran, followed by a solution to the Arab-Israeli dispute. ${ }^{75}$

Eisenhower was particularly leery of supporting Churchill in Britain's dispute with Iran and Egypt. In February 1953, referring to the "somewhat frightening phraseology" of Churchill's private correspondence, the president made it clear that he feared British attempts to "tie our hands in advance" in Egypt. ${ }^{76}$ Egypt was critical to planned U.S. policy for supporting progressive regimes. Washington also wanted to revive the Middle East Defense Organization previously advocated by the Truman administration. In Churchill's view, the Middle East was a traditional British sphere of influence and its oil was a necessity for continued British influence and prosperity. The thought of Washington mucking around in the region and taking sides on behalf of emerging progressive regimes was alarming.

Given its early statements on the region, why did the Eisenhower administration within a year participate in the overthrow of Muhammad Musaddiq's elected government in Iran? The answer is straightforward-the containment of the Soviet Union required a pro-Western Iran with security ties to the West. Musaddiq's confrontation with London over British oil concessions 
resulted in instability. Washington lamented the inability of Shah Muhammad Reza Pahlavi to hold his own against Musaddiq and his National Front supporters. Dulles stated, "Prime Minister Mossadegh could not afford to reach any agreement with the British lest it cost him his political life." Dulles also flatly stated that Musaddiq was not a Communist, citing "secret radio" attacks on Musaddiq by the Soviets for being "a vile servant of the Shah." Trying a new tack, the British argued that Musaddiq's instability and volatility would result in a leftist coup that would bring the Communists to power. This British argument resonated, but Washington wanted to avoid intervention and proposed to strengthen Musaddiq's position through additional economic assistance. ${ }^{78}$

London vociferously complained that U.S. support would result in an irreparable loss of British face, not to mention oil royalties to support the pound. ${ }^{79}$ In addition, they did not trust Dulles, who had represented several U.S. oil companies in his private law practice. Still trying to avoid intervention, Washington played on Islamic conservatism and instigated an antiSoviet, anti-Communist "psychological strategy program." ${ }^{" 10}$ Instability increased and as a result, Eisenhower concluded that the Musaddiq government had to be replaced. ${ }^{81}$

The successful coup had the support of most of the Shi'a religious establishment, right-wing politicians, the wealthy classes, and conservative military officers led by General Fazlullah Zahedi. Zahedi restored the Shah to the throne, crushed the Communist Tudeh Party, suppressed the leftist National Front, and handed the Iranian petroleum to an Anglo-American consortium. The coup defused the immediate crisis, but did little to solve the problem of Iranian stability. A few months later, Secretary Dulles complained that the Shah and Zahedi had failed to enact "critical" economic and social reform and the only bright spot was the suppression of the opposition. Most of the Tudeh leadership was in jail, the National Front ceased to be an immediate factor, and British-Iranian relations had resumed. ${ }^{82}$

The success of the Iranian coup established a U.S. policy model. The reform policies of nationalist politicians in the Middle East tended to create political instability, which in turn opened the door for Communist and Soviet inroads. Conservative military officers supported by the Islamic leadership were an effective ideological bulwark against Communists and anti-Western leftists. Real faith lay in the conservative military and security services, not only as the foundation for stability, but also as the potential 
instrument for controlled reform. Finally, Islam and the religious establishment across the region constituted a natural enemy of Communism and leftists and another potential ally in the Cold War. This support for religious conservatives served the U.S. well for almost four decades in combating Soviet influence and hostile nationalist regimes. ${ }^{83}$

From Eisenhower until Carter, administrations supported the Shah's government as a hedge against the rise of leftists in the region. It was the rationalization for the 1953 coup. In the Kennedy Administration, the "Iran Task Force" headed by Deputy Assistant Secretary of State Phillips Talbot was obsessed with the National Front and the Tudeh. ${ }^{84}$ Even in the late 1970s, fear of leftists and Communists-the Cold War mentality-created a U.S. preference for the Ayatollah Khomeini over a leftist government in Tehran. There was little recognition that a fundamental change was occurring-the Ayatollah represented a new kind of adversary-nationalistic, religiously fundamentalist, and anti-American.

Ironically, a simultaneous set of developments brought neighboring Pakistan by a different route to almost the same situation. The partition of India and the creation of Pakistan in 1947 was a chaotic, bloody nightmare that left the new Muslim state on virtual life-support. By the 1950s, Pakistan had emerged as an asset in the Cold War struggle against the Soviet Union, including the Central Intelligence Agency (CIA) facilities at Peshawar which enabled U-2 operations over the Soviet Union. In 1956, a new Pakistani Republic elected a new government. Within a year, the Pakistani military was hinting at the possibility of coup to restore order. The Eisenhower administration told the Pakistani generals and particularly Ayub Khan, the Chief of Staff, that democracy should have a chance. A standoff of sorts existed until 1958.

Shocked by the July coup in Iraq and the destruction of the anti-Communist monarchy by a radical nationalist military regime with the backing of the Iraqi Communist Party, Washington shifted from opposition to a coup in Pakistan to neutrality on the issue. In October 1958, the military took over the government and Ayub Khan became president. ${ }^{85}$ Military spending approached 65 percent of the budget. Key U.S. officials knew that requests for arms were in fact a 'hoax' to acquire arms to control the Pashtun tribes and to confront India, but the need for a continued pro-Western political stance in Karachi forced them to look the other way. ${ }^{86}$ The Pakistani military was anti-Communist, as was the society as a whole, and India and Afghanistan 
were non-aligned and neutral. The policy of containment made Pakistan, no matter how unstable, a necessary ally.

Between 1958 and 1971, Pakistan fought and lost two wars with India. It lost East Pakistan, now Bangladesh. In the 1971 war, the Nixon administration cut off military aid and support creating a crisis in U.S.-Pakistani relations. In the aftermath of the 1971 disaster, Zulikar Ali Bhutto became Martial Law Administrator and then Prime Minister from 1973-1977. Recognizing Pakistan's weakness vis-à-vis India, Bhutto initiated a nuclear weapons program. He was overthrown and then executed by General Zia-ul-Haq. Bhutto was American and British educated and secular in outlook; Ziaul-Haq was a Muslim fundamentalist military officer that crushed secular opposition and Islamized the Pakistani government and military. In 1979, Haq stood by while mobs sacked and burned the U.S. Embassy in reaction to an erroneous report that the U.S. had been responsible for the takeover of the Grand Mosque in Mecca. ${ }^{87}$ In the 1980s, the Reagan Administration made Pakistan and Haq the conduit for aid to Afghans and foreign Islamic fundamentalists fighting the Soviets in Afghanistan. His rule empowered the radical Muslim fundamentalists in both Pakistan and Afghanistan with whom NATO forces now contend.

For four decades, despite its political instability and insatiable demands for modern weapons, the U.S. viewed Pakistan as a critical ally in the Cold War. Yet Pakistan did not directly confront the Soviet Union. Pakistan was a counterbalance to neutral India and Afghanistan. Perhaps more importantly, it was the site of major technical intelligence operations against the Soviet Union. In 1979, the Soviet invasion of Afghanistan made Pakistan the conduit for bleeding Moscow through an unwinnable war. It served to tie Pakistani interests to the radical fundamentalist regime that eventually emerged in Afghanistan. Nowhere was the linkage between a conservative, authoritarian set of regimes and Islamic fundamentalism and the progression from Cold War ally to post-Cold War frictions starker than with Pakistan. The United States went from being perceived by Muslims as being an ally of Muslim fundamentalism to being perceived by many Muslims as at war with Islam in roughly a decade. In a broader context, the ally of the 1980s has become the widely despised and broadly viewed by the population either as the outright enemy of Islam or as a destabilizing force that supported military dictatorship and undermining the fabric of the nation. 
Current American support for the civilian government has netted little in the way of an improved U.S. image.

\section{Indonesia Experience}

In Indonesia, a similar progression occurred. In 1945, Sukarno, the leader of the independence movement, formulated an Indonesian constitution based on the Five Principles. It was in effect a fusion of Marxist theory, nationalism, and Islam. Between 1945 and 1950, Sukarno put down an insurgency by the Indonesian Communist Party and successfully challenged Dutch attempts to reestablish control. ${ }^{88}$ The political landscape included three major parties-a secular nationalist party, an Islamic party, and the newly legal Communist Party and their struggle for control. After years of instability and multiple military rebellions, a new governmental system emerged in 1955, a divided government between the secularists and the Communists.

In 1956, Sukarno declared martial law, rejecting democracy as unworkable, he moved toward authoritarian rule with the army as the ultimate authority. In 1957, radical Islamists attempted to assassinate him and were ultimately crushed. That same year he began nationalizing foreign firms and tolerating more Communist influence in the government. By 1958, antiSukarno army officers had formed an alliance with conservative Muslim political elements in opposing the central government and its increasing Communist influence. Fearing a Communist takeover, the U.S. provided covert support to the rebels. Here again is the preference for conservative anti-Communist army officers allied with Muslim political elements. Sukarno defeated the rebels and reinstated presidential rule. In 1960, Sukarno replaced parliament with a new legislative body in which he appointed half of the members. He also banned the Islamic parties and moved against his political opponents. The military loyal to Sukarno crushed Muslim opposition, and to counter the power of the military Sukarno moved more Communists into key positions in the government. ${ }^{89}$

Equally troubling to the U.S., Sukarno opened relations with Beijing and openly courted support from the Soviet Union. In the early 1960s, he attempted to annex territory recognized as Malayan and advocated the establishment of Communist rule in the new territory. In 1964, the British Embassy was burned and British companies in Indonesia were nationalized. As the American government attempted to rein him in by cutting aid, 
Sukarno launched an anti-American campaign in which U.S. businesses were attacked by Communist mobs in Jakarta. He moved closer to China. He also tolerated Communist collectivization efforts in the countryside. The army became increasingly disaffected with Sukarno and hostile to the Communists, particularly when they began to form an armed force of their own. On his Independence Day speech of 17 August 1965, Sukarno declared his intention to commit Indonesia to an anti-imperialist alliance with China and other communist regimes, and warned the Army not to interfere. He also stated his support for the establishment of "fifth force" of armed peasants and labor. ${ }^{90}$

In October 1965, Communist sympathizers in the Indonesian military kidnapped and executed six of the most senior officers. Major General Suharto escaped and took command of the Indonesian military. Allied with Islamic elements, he systematically crushed leftists and Communists of all stripes. It is estimated that 500,000 were killed and over one million imprisoned. In effect, two of the three pillars of the Indonesian political system - the military and Islamists - had united to destroy the third, the Communists. Given the Cold War pressures of the time and the situation in Vietnam, it is hardly surprising the U.S. wholeheartedly supported Suharto. Sukarno was removed and died in 1969. Suharto ruled Indonesia until 1998 when the economic crisis in Asia brought down the regime. Islamist parties dominated the democratic regime that replaced Suharto's rule. The violent opposition to that regime came from radical Islamist jihadi splinter groups that were violently anti-American.

The Cold War paradigm of allying with conservative politicians, military officers, and Islam reached the height of its complexity in the Arab Middle East. Despite pressure from British Prime Ministers (Churchill and Anthony Eden), the U.S. refused to undertake an Iran-like operation against Gamal Abdul Nasser in Egypt. Kermit Roosevelt, the grandson of President Theodore Roosevelt and the CIA officer in charge of the Iran coup, assessed the situation and refused to participate. ${ }^{91}$ Nasser was wildly popular in Egypt and supported by a loyal military. In 1954, the U.S. acted as the go-between pressuring the British and Egyptians to come to an agreement about British withdrawal from the Suez Canal Zone. ${ }^{92}$ The final agreement included a series of clauses that described the circumstances under which the British military could reoccupy the canal. 
The Muslim Brotherhood had backed Nasser in his overthrow of General Muhammad Neguib, the first president of Egypt (1952-1954), but when he accepted the compromise with the British, the Brotherhood attempted to assassinate him. He outlawed the party and crushed it. ${ }^{93}$ The U.S. had verbally promised Nasser massive economic and military aid in return for the compromise-it was not forthcoming. He also believed the U.S. would use its influence to limit Israel provocations-instead provocations increased, including an attack on Gaza in which dozens of Egyptian policemen were killed. Nasser had little to show for the risks that he had taken at U.S. prodding. From Cairo, it appeared that the West intended to strengthen Egypt's enemies and undermine Nasser's prestige. ${ }^{94}$

Just as Nasser's frustrations with the West reached their peak, Nehru invited him to attend the Non-Aligned Conference at Bandung, Indonesia. Nasser found himself feted and flattered by Nehru, Marshall Josip Broz Tito of Yugoslavia, and Achmad Sukarno of Indonesia. Nasser announced from New Delhi, "that the only wise policy for us (Egypt and the Arabs) consisted in adopting positive neutralism and nonalignment." ${ }^{\prime 95}$ From an Egyptian perspective, Nasser, "went to Bandung an Egyptian and returned a world figure and revolutionary." ${ }^{\prime 96}$ In secret discussions, Chou En-lai, the Chinese Premier, offered to broker an arms deal for Egypt. The Soviets offered modern weapons on generous payment terms and assistance with the Aswan Dam project. Nasser hoped for an American counter-offer but none was forthcoming and he signed the so-called Czech arms deal on 27 September 1955. ${ }^{97}$

In Washington, the arms agreement was a shock. It linked Egypt and non-alignment to pro-communist policies. By the arming of Egypt, the Soviets were in the Middle East and the U.S. was scrambling for a response. ${ }^{98}$ Between 1955 and 1958, Washington saw Nasser as the "cat's-paw" of the Soviet Union. The administration could not differentiate between Egyptian national interests and its relationship with the Soviet Union and Communism. Washington focused on the conservative monarchies-Jordan, Iraq, Saudi Arabia, Iran - to combat the expansion of Nasserist influence.

Then in 1958, Nasser unified Egypt and Syria and formed the United Arab Republic. Washington realized it needed a modus vivendi for some type of understanding with Cairo. In addition, instability in Syria resulted in Nasser initiating an eye-opening set of policies. The Syrian Communist Party threatened stability, and leftists in Egypt were also becoming more outspoken. Nasser cracked down on the Communist groups. As his security 
forces were crushing the Communists at home, he was feted in Moscow as a friend of the Soviet Union. The U.S. concluded that these developments warranted a reexamination of its policies. ${ }^{99}$

Then, in July 1958, the Hashemite monarchy in Iraq collapsed in a military coup. Given the longstanding animosity between Baghdad and Cairo, initially Eisenhower thought that Nasser was responsible. CIA assessments viewed the long-term British position in Jordan and Iraq as untenable, contributing to the concern that none of the conservative Arab monarchies would survive the Arab nationalist surge. ${ }^{100}$ In reaction, the U.S. deployed Marines to Lebanon and the British landed paratroopers in Jordan to forestall 'Nasserist' coups. As it turned out, the coup in Baghdad was an Iraqi not a Nasserist coup, and within a matter of months, Cairo and Baghdad were at each other's throats in a prolonged struggle that would become known as the "Arab Cold War."

King Hussein in Jordan appeared to be in trouble, and Saudi Arabia was undergoing a leadership crisis. Eisenhower had what he described as "a choice between Al Capone and John Dillinger."102 Nasser and his clear anti-Communist stance in Syria and Egypt were by far preferable to Abdal-Karim al-Qasim, the revolutionary leader of Iraq who had now become the darling of Moscow in the region and who relied on the Iraqi Communist Party for support. Open friction between Moscow and Cairo ensured that in the struggle with Qasim and Iraq, Nasser would have the backing of the U.S. ${ }^{103}$ This of course did not mean that Nasser was no longer a threat to U.S. interests and its monarchial allies, but it did mean the U.S. had moved from a simplistic policy based on the idea that monolithic ideology really existed to one in which allies were picked on an issue-by-issue basis.

This more sophisticated view resulted in a nuanced set of policies. The U.S. encouraged Nasser's animosity toward Iraq, Moscow's new darling in the region. For Washington, the Communists posed a global problem; for Nasser, the revolutionary apostates in Baghdad threatened his view of Arab nationalism and unity. For their own reasons, the Egyptian president and the Eisenhower administration agreed on policies toward Qasim's Iraq. By the end of 1958, Nasser had concluded that the real threat to his leadership of the Arab nationalist movement lay in Baghdad. In discussions with William M. Rountree, the Assistant Secretary of State, Nasser offered, "a scarcely-veiled invitation to collaborate on Iraq." 104 When a Nasser-backed coup failed in March 1959, the Baghdad press railed: 
Abdel Nasser is revealed as the great plotter, enemy, shedder of blood. Those who proclaim pan-Arabism and raise Abdel Nasser to the rank of prophet have been exposed. Nasser sent arms to Mosul because he wanted to annex Iraq to his kingdom. ${ }^{105}$

The Iraqis called Nasser the "foster son of American imperialism."106 This war of words became a covert struggle to overthrow the government in Baghdad and its Communist allies. Qasim nationalized British oil interests, threatened to invade Kuwait, and threatened to overthrow all the monarchies and emirates of the region. ${ }^{107}$ In 1963, a coup in Baghdad led by nationalist and Nasserist army officers and Ba'thists under Abd-al-Salaam al-Aref took over the government, executed Qasim, and systematically slaughtered the Communists. The U.S. encouraged the new Iraqi regime to eliminate the Communist threat once and for all. ${ }^{108}$ King Hussein of Jordan is said to have stated that he knew "for a certainty" that the coup had the support of U.S. intelligence. While the U.S. government supported the coup, the key elements were the Iraqis and their regional allies. ${ }^{109}$

While the case-by-case approach would pay off in dealing with Nasser; he was still a problem for U.S. interests. He continued to try and undermine Jordan, Saudi Arabia, and the Gulf States. He supported successful revolutionary movements in Algeria and Libya, and he even tried to impose himself in places like the Congo. The mutual (U.S.-Egypt) agreement on the need to do something about Qasim also did not mean that the U.S. was unwilling to undermine Nasser. In 1962, Nasser and opponents of the Imamate in Yemen overthrew the government and created the Yemen Arab Republic (YAR). ${ }^{110}$ A civil war erupted when the Egyptians and their allies failed to kill the Imam. Initially the U.S. remained neutral, but as conservative regimes, Saudi Arabia and Jordan with British backing began to supply the Royalists while the Egyptians staged air raids on southern Saudi Arabia.

The U.S. backed the Saudis politically and militarily by basing U.S. Air Force units in the Kingdom. In a confused bloody struggle, Wahhabi Saudi Arabia, Hashemite Jordan, and the British bled the Egyptian army and drained Nasser's treasury. Ironically, this was done to support Royalists who were for the most part tribal Zaydi Shi'as. Nasser's expansionism and the threat to Saudi Arabia forced Washington to de facto side with Saudi Arabia and the religiously conservative tribal elements against Nasser and the secular republican regime. 
In 1967, the disastrous defeat of the Egyptian, Syrian, and Jordanian armies in the Six Day War with Israel and the rise of an openly pro-Communist regime in south Yemen would result in yet another set of policy shifts. First, the Egyptians were forced to withdraw their troops from Yemen. Continued fighting and more compromises brought the elimination of leftists in the YAR army and replaced them with tribal and conservative Islamic elements. In broad terms, the YAR passed into the hands of conservative tribal elements backed more or less by Saudi Arabia and the United States. The new government of South Yemen was now controlled by fractious leftist elements-socialists, Communists, and other leftist groups-with the support of the Soviet Union, China, and nationalist Arab regimes like Egypt. The South Yemenis sponsored insurgencies in the YAR and Oman and also provided training and refuge for various terrorist organizations and their operations. The U.S. and Saudi Arabia confronted the threat posed by the south with an alliance of conservative social and religious elements including what would now be viewed as Islamic fundamentalists. Once again, conservative regimes and Islam, backed by a reliable military establishment, were the preferred allies and the pillars of U.S. policy in the Islamic world.

\section{The Crisis of 1979 and a Decade of Change}

The year 1979 presented the United States with a series of crises that signaled the beginning of profound change for its political and diplomatic position particularly in the Islamic world. ${ }^{111}$ A series of events would begin to change the perception of the U.S. in the Muslim world in general and the Middle East in particular. The year began with what would have been unthinkable even 12 months before. A combination of religious conservatives, leftist organizations, reformists, constitutionalists, and a popular uprising toppled the regime of Shah Muhammad Reza Pahlavi in Iran. Even as the Shah's regime collapsed and the Ayatollah Khomeini arrived in Tehran to take charge, the focus in Washington was on the National Front, the organization that had almost toppled the Shah in 1953, and leftist and Communist organizations. While there was obviously a clear U.S. and Western preference for the Shah's regime, the Islamic fundamentalists were preferable to leftists or radical nationalists. It would take months for the U.S. foreign policy apparatus to begin to understand that something fundamental had changed in Iran and that Khomeini and his supporters represented a point 
of view that was as implacably anti-American as the leftists had ever been. In effect, "group-think" and policy "tunnel vision" contributed to the rise of the Khomeini's state. ${ }^{112}$

In July 1979, Saddam Hussein, the strongman behind President Ahmed Hassan al-Bakr, removed the president and took power. In September 1980, the chaos in Iran resulting from the fall of the Shah and the realization that Khomeini really intended to export his Islamic revolution resulted in Saddam Hussein ordering the invasion of Iran. ${ }^{113}$ Before it was over, both Iran and Iraq were economically crippled and the war had spread to the Gulf creating the 'Tanker War' of the 1980s. The rise of Khomeini and Saddam ushered in a period of conflict that saw the invasion of Kuwait and the destruction of Sunni Iraq, and the beginning of an open Sunni-Shi'a confrontation that continues today. For the first time, the hostility of an Islamic government pushed the U.S. into a new uncomfortable relationship with a radical nationalist state that was the embodiment of policies that the U.S. had systematically opposed since the 1950s.

In March 1979, Egypt and Israel signed a treaty that was the culmination of the Carter Administration efforts to bring peace to the Middle East. The treaty created a crisis in the Middle East and the Islamic world with broad condemnation of Egypt's President Anwar Sadat and the United States. Egypt was expelled from the Arab League for a decade, but in return for signing the treaty, Egypt received massive amounts of U.S. aid and Israel withdrew its occupying forces from the Sinai. There was also a far-reaching implication; the treaty served as a catalyst for the further radicalization of Middle East politics. It spurred Islamist opposition to the Egyptian government.

Suppressed since the 1954 attempt to assassinate Nasser, the Muslim Brotherhood splinter groups reemerged that were ideologically in the vein of Sayyid Qutb (1906-1966), the theorist who advocated violence against Nasser's regime. Qutb was executed in 1966 for 'inspiring' the conspirators planning another assassination attempt against Nasser. Qutb and his followers, the Qutbi, became the inspiration for the radicals who eventually succeeded in assassinating Sadat in 1981. One of those arrested in the aftermath of the Sadat's assassination, Ayman Zawahiri, was deeply influenced by Qutb's ideas as related by Zawahiri's uncle and became the theoretician and the driving force behind al-Qaeda. Those ascribing to Qutb's ideas despised secular Arab nationalism, American secularism, European socialism, and Soviet Communism. ${ }^{114}$ From the U.S. perspective, the 1979 
peace treaty between Israel and Egypt simplified the ideological conflict for many Egyptians by linking the government in Cairo directly to U.S. policy. For the next 30 years under Hosni Mubarak, Islamists would view both the Egyptian government and U.S. influence as the enemy.

Another crisis in 1979 resonates today. The long simmering border issues between the YAR and the Peoples' Democratic Republic of Yemen (PDRY) broke into open conflict in February. The entire affair was controversial because to a significant degree, the conflict ignited when tribal forces-supported by Saudi Arabia and over which the government in Sana'a had no control-provoked the conflict. This was done in part to undermine unification talks between the YAR and PDRY. PDRY forces made dramatic gains, and the Saudis refused President Ali Abdullah Salih's request for direct support. ${ }^{115}$ This situation precisely fit the Cold War model. The U.S. rushed military aid to Sana'a and began to actively take measures to exacerbate political factionalism in Aden. It also incited conservative Islamic and tribal groups against the Soviet sponsored regime in the south. It began in earnest an off-and-on alliance with Salih's government that would last more than 30 years. The U.S. supported the invasion of the Sunni south by the Zaydi Shi'a dominated north and southern tribal dissidents and found itself the supporter of a failed government centered on the Salih family and Zaydi tribal leadership. The U.S. position in Yemen became a recruiting poster for southern separatists, Zaydi Huthi dissidents, Sunni Islamists, and al-Qaeda in the Arabian Peninsula.

In November 1979, a group of zealots inspired by Sheikh Abd-al-Aziz al-Baaz, the Grand Mufti of Saudi Arabia, took over the Grand Mosque in Mecca. Their leader, Juhaiman ibn Muhammad al-Utaibi, announced his opposition to the Saud regime and Western influence in the Kingdom and declared that his brother-in-law, Muhammad Abdullah al-Qahtani, was the Mahdi and the apocalypse was imminent. A two-week siege ensued in which scores of Saudi security troops were killed, the government managed to retake the Mosque, capture the rebels, and eventually try and execute them. For the Saudis, the siege was a major embarrassment that seemed to indicate a greater level of instability than previously suspected. ${ }^{116}$ For U.S. policy, the siege was a harbinger of things to come. The Ayatollah Khomeini declared that the violation of the Grand Mosque was obviously the work of "criminal American imperialists and international Zionism." ${ }^{117}$ Anti-American rioting broke out from North Africa to the Philippines. 
In Pakistan, the situation spiraled out of control. Pakistani President Zia-ul-Haq transformed Pakistan from a nominally secular political system to one that was Islamic. When demonstrations and rioting broke out as a result of Khomeini's accusations, Haq sat idly by while Islamic organizations bused additional rioters to the U.S. embassy. Eventually, the rioters burned the embassy to the ground, killing two Americans in the process. Pakistani security forces never intervened. After the fact, the Pakistanis offered a number of less than plausible explanations, but the U.S. never pressed the issue because the Cold War situation created a requirement for Pakistani cooperation. ${ }^{118}$ There had been numerous issues between the U.S. and Pakistan, most of which related to Indo-Pak issues and dated from the Ayub Khan era in the 1950s, but 1979 stands as a clear indication that not only had the political system in Pakistan changed but also that the future of U.S.-Pakistani relations would be more problematic.

The burned embassy notwithstanding, within a few weeks, the Cold War played into Pakistan's hands. In December 1979, at the request of the leftist government in Kabul, Soviet troops entered Afghanistan. It began a war in which the United States embraced not only an increasingly Islamic fundamentalist Pakistani state, but also the tribal fundamentalists in both Pakistan and Afghanistan. Haq and the Pakistani Directorate for Inter-Services Intelligence gained control not only of the flood of U.S. funding for the anti-Soviet effort, but also acquired what amounted to controlling influence over the post-war political environment. The U.S. and Pakistan were pursuing their differing strategic interests and both achieved their immediate strategic goals. U.S. intervention bled the Soviet military in a war that became absolutely unwinnable and crippled a failing economy, and Pakistan used U.S. funding to co-opt its troublesome Pashtun tribes and to extend its influence in Afghanistan. ${ }^{119}$ For both it appeared to be the successful culmination of struggles that had begun in the immediate aftermath of World War II-that is until 11 September 2001.

A decade of change, initiated in 1979, fundamentally reordered the political position of the United States in the Islamic world. For roughly four decades, Washington had relied on conservative regimes, often military in origin, and on the conservatism of Islamic societies to combat the influence of the Soviet Union, China, and their proxies. The approach was also marginally effective in limiting the influence of the secular nationalist regimes. ${ }^{120}$ It was a Cold War paradigm where Islamic conservatives and even some 
radicals saw the U.S. as useful. The rise of politicized Islamic states in Iran and Pakistan institutionalized a more radical kind of political Islam and the collapse of the Soviet Union in 1989 removed the common enemy of political Islam and the United States.

The Second Gulf War sparked by the Iraqi occupation of Kuwait also served to underscore in the minds of many Muslims that the only remaining superpower was ideologically and culturally only a marginal improvement over the Soviet Union and its allies in the region. A Ba'thist and secularist, Saddam Hussein was unpopular in much of the region, but to many he was preferable to the oil-rich rulers of the Gulf and their American allies. Even many of those who opposed Saddam and supported the removal of the Iraqis from Kuwait were troubled that Arabs or Muslims could not do it themselves. The idea that foreign, Western troops were necessary was a form of humiliation. The ejection of Iraqi troops from Kuwait, no matter how necessary, raised the profile of the United States in the Muslim world at just the time the U.S. had emerged as the only global power. The U.S. and its Muslim allies became a lightning rod for the discontented and the radicalized elements in multiple Muslim societies.

\section{Summary}

There existed a decided lack of awareness or lack of appreciation for the scope of change that the overall political position of the United States had experienced. Many key policies continued to follow the Cold War pattern. In addition, the collapse of the Soviet Union encouraged a level of hubris. This is all understandable but nevertheless problematic because the U.S. carried its views of what the world should be-as opposed to what it actually is-into several very complex situations. In many respects, it represented two key attributes of the Progressive Era thinking that has dominated American politics for a century. It was the worst of Theodore Roosevelt and Woodrow Wilson-the 'big stick' combined with an absolute faith in Western democracy. This lesson, first learned between 1954 and 1975 in Vietnam, had to be reacquired.

Yemen provides a prime example. In 1990, the U.S. applauded the unification of the YAR and PDRY as the creation of a new, united, democratic state on the Arabian Peninsula. Ali Abdullah Salih and conservative Zaydi tribal interests dominated the north. The north had never functioned as a 
real nation-state. Former socialists and Communists-Soviet and Chinese clients-controlled the south. Thus Washington was pleased when Salih, an on-again-off-again ally emerged as president of the new unified republic. Ironically, it was only the south that had even come close to functioning as a real national state. The northern Zaydis and southern secularists and Sunnis erupted in civil war in 1994. The U.S. backed Salih's conquest of the south, a conquest in which Zaydi tribesmen and Islamic fundamentalist elements were allowed to sack southern cities and bring them back under northern control.

From a U.S. perspective, the northerners had been allies in the Cold War; the southerners were the old socialist, Soviet client regime. The southerners viewed the U.S. as the ally of their northern enemies and it is among the southerners, including westernized elements, that al-Qaeda in the Arabian Peninsula (AQAP) has been able to mount its current offense not only against their local enemy-the government in Sana'a-but also against that government's biggest supporters-the United States and Saudi Arabia. The conflict between Sana'a and Aden dates from the advent of Zaydi Shi' ism in Yemen, and the U.S. has taken sides in the conflict-hence making Washington the perfect recruiting poster for AQAP or any other southern based violent jihadi group.

Yemen is just one example. With regard to the Muslim population in the Philippines, Thomas McKenna points out:

[Moro] leaders manifestly rejected the underlying goal of American colonial policy toward Philippine Muslims-their integration into a unified, Christian-dominated, post-colonial state-yet embraced the idea of a transcendent Muslim Philippine identity as well as the term 'Moro' itself. ${ }^{121}$

For the radical Philippine Muslims that have joined Abu Sayyaf, this paradigm continues to hold sway-despite the existence of an autonomous Muslim state on Mindanao, the U.S. continued to work with and support that old goal of 'American colonialism.' Thus, the government in Manila and its representatives in the south, along with its American backers, are the enemy and for some radical disaffected subset will always be the enemy.

Academic discussions about the "end of terror" abound. ${ }^{122}$ This is problematic on at least two counts. Terror is not a movement; it is a tactic. It is an effective weapon of the weak against the strong. If a nation is perceived 
as the richest and strongest nation on earth, particularly one that attempts to directly or indirectly impose its view of acceptable political and cultural norms on starkly different societies, then that state will have enemies. For some subset of those enemies, terrorism will be the weapon of choice. It is not something uniquely Islamic, nor is it something that has come into vogue in the last 150 years as some would argue. It is merely a tactic. Second, with regard to Islam, the United States sometimes, out of a necessity driven by national interests or out of misplaced good intentions, has taken sides in regional or local political and cultural conflicts. There are things that might reduce the reaction in the future, but the invasion of Iraq and U.S. involvement in Afghanistan, Yemen, Indonesia, the Philippines, and other areas confronting Islamic extremism guarantees that from a policy perspective any talk of an 'end of terror' is premature. 



\title{
3. The Islamic World: Politics and Extremism
}

\begin{abstract}
iven the fractured nature of the Islamic umma, compounded by the conflicting political interests and the new alignment and changed perceptions of the United States, a concise examination of contemporary Islam and its attributes is in order. In Winning the Right War, Philip Gordon criticized the idea of a global war on terror stating:
\end{abstract}

[The U.S.] is fighting against an alleged single enemy, when the enemy is extremely diverse ... It is focusing on a tactic, terrorism, when the real issue is how to address the political, diplomatic, social, and economic factors that lead people to use that tactic. ${ }^{123}$

This conflation of terrorism with Islam and ideology compounded the problem. This chapter analyzes Islam not in terms of some ideal or the pronouncements of ideologues with a political agenda, but rather in terms of political attributes, and those are manifested in the current environment. As one analyst put it:

Post 9/11, significant sections of the Western media have tended to misrepresent Muslims as a monolithic nation, a supposedly unified Global community of believers-sharing a national consciousness that subsumes their diverse ethnic, cultural linguistic, national, racial, or territorial identities under an all-encompassing identity of the 'Ummah.' The disparate Muslim nationality movements of Palestine, Kashmir, and Chechnya are being clubbed with fringe pan-Islamic militant movement like Al-Qaeda and seen as part of a putatively wider 'Global Islamic Jihad' against the West. ${ }^{124}$

This simplification is not limited to the media but reflected in policy and in the views of wider Western society as a whole; it is a mistaken simplistic view.

This evaluation will take a different cut at understanding the relationship between secularism in the Islamic world, Islamic fundamentalism, Salafist ideas, and radical jihadist movements. Following a brief discussion of the demise of secularism, this section will evaluate Islam in terms of the 
political, economic, and social diversity that drives diverse ideological interpretations that find expression in Sunni, Shi'a, and Pan-Islamic ideology, political structures, and radicalism. This differentiation in the meaning and concept of jihad illustrates the fundamental structural differences between Sunni and Shi'a approaches to religious authority. Citing an "important difference" between al-Qaeda and Hezbollah over the discourse on jihad, Rola al-Husseini, an Assistant Professor at the George H.W. Bush School of Government, stated:

Al Qa'ida's religious legitimation of jihad is done by lay thinkers who are self-taught ulema (scholars), such as Sayyid Qutb or Abd Al-Salam Faraj, while Hizbullah's understanding of jihad is based on the works of Shi'a religious scholars classically trained in the Fiqh tradition of the Najaf hawza. ${ }^{125}$

It is the difference between a structured hierarchy in religion and politics that has broad authority, and the diffuse Sunni community and its largely self-educated clergy.

The premise of this chapter is that the current world of Islam in many respects is no different from the Islam during other periods-its fundamental attribute is not unity but rather a diverse set of completing and conflicting interpretations and ideologies that overlay an even more complex political and cultural topography. In many respects, the situation resembles more of an Islamic civil war. It is into this Islamic civil war with the best of intentions and a stunning level of naiveté that the United States has interjected itself. The only beliefs that many Muslims share about the U.S. are that the U.S. supports Israel's domination of the Palestinian people, the U.S. had no real justification for invading Iraq, and U.S. involvement in Afghanistan is ill-advised and illegitimate. Depending on the particular individual persuasion of those involved, there is general opposition to specific U.S. policies in the Islamic world that does not come from just the terrorists. The following takes a sectarian perspective on the conflict. In general terms, it is intended to provide insight into the complexity of a world in which Islam provides the language and discourse for struggles that are fundamentally political and cultural. 


\section{Sunni Islam: Community and Conflict}

Within the Islamic community, the Sunnis account for approximately 85 percent of all Muslims, an estimated population approaching 1.5 billion. This population is anything but monolithic. In fact, the growth and vitality of the umma is a testament to flexibility and adaptability of Sunni Islam. Those claiming to be Sunni are a highly diverse political, economic, social, and cultural group. The size of the group, their cultural diversity, and the diversity of the political and economic interests makes even the use of the term 'Sunni' a perplexing, complex task. By definition, the task of providing a detailed analysis exceeds the scope of this study. But given that radical jihadist organizations are composed almost entirely of Islamists who came out of the Sunni traditions, this overview is not only warranted but also critical as a baseline for understanding some of the sectarian issues and political movements.

Two additional issues are factored into the discussion of Sunni radicalism-the rise of non-state actors and the concept of conflict on the periphery. The rise of the non-state actor is not limited to Sunni-based organizations, but in the Shi'a tradition virtually all the non-state actors are tied to or function as a part of larger political entities that have many of the attributes of a state-Jaish al-Mahdi, Hezbollah, et cetera. In the Sunni tradition, the non-state actors tend to account for the majority of the violent jihadist organizations, and their ties to functioning political entities are either far more tenuous or nonexistent. This lack of structure is also manifested in the role Sunni-based organizations tend to play in clashes on the Islamic periphery. In Mali, Nigeria, Sudan, and Somalia, African radical violent organizations dominated by Sunnis constitute a growing regional threat to stability. In Chechnya and Dagestan, radical Sunni groups threaten the integrity of the Russian state. Across Southeast Asia, the story is the same in Indonesia, Malaysia, Thailand, and the Philippines; Sunni splinter groups are the source for militancy and terrorism. ${ }^{126}$ Perhaps, the greatest threat of all is from the metaphorical periphery-almost always Sunni in origin-where individuals or small cells disaffected with the West and their personal plight often suffering a personal crisis turn to violent radicalism as a solution. Although not the sole province of Sunni Islam, these threads tend to be interwoven more often into the Sunni radical narrative. ${ }^{127}$ That said, the most important allies of the West in the Muslim world are Sunni states in the Arabian Gulf. In fact, 
the West's most important ally in the Middle East is the most conservative of Sunni states, Saudi Arabia. This reality amplifies the complexity of policy issues in places like Syria and Iraq.

The term Sunni comes from the term in Arabic that refers to the saying and actions of the Prophet-the Sunnah. These actions were recorded in the Kutb al-Sitta of the Hadith where the actions of the Prophet are recorded. Loyalties in the Sunni community were complicated even at a relatively early stage as subdivisions appeared. Among the Sunni, four schools of Islamic law (madhhabs) emerged: the Hanafi, the Shafai, the Maliki, and the Hanbali. Each espoused its own way of interpreting Islamic law. Generally speaking, adherents to all four schools recognize the others as legitimate, but at the same time technical arguments about the interpretation of law have often been the basis of communal conflict. In short, as with any of the monotheistic religions, seemingly insignificant points of doctrinal differences have often become the rallying points for political struggles for power. Legitimacy or greater legitimacy as the issue has been a catalyst for conflict. ${ }^{128}$

Roughly speaking, the four schools came into being in the century between 750 and 850. Imam Numan ibn Thabit Abu Hanafi (699-767) established the first in Kufa, Iraq. Abu Hanafi's family heritage was most likely Persian or Afghani. At the time, Kufa was a hotbed of revolt against the Umayyad Caliphate in Damascus. Ironically, it would be the Abbasid Caliph al-Mansur that imprisoned and likely ordered Abu Hanafi's elimination for refusing to accept the position of chief judge in the Abbasid administration and for opposing al-Mansur's rule. He knew Jafar al-Saddiq (the sixth Imam in Shi'a belief) personally and revered him as the most learned imam in Islam. The Hanafi School is regarded as more liberal in the sense that places significant weight on the role of reason in legal interpretations. It was the chosen school of the Abbasid Caliphate, the Ottoman Empire and the Mughal Empires. The fact that it left significant leeway for interpretation and application of law based on reason made it the preferred legal approach in empires that had to deal continually with complex, heterogeneous political, economic, social, and cultural environments. It is the largest school of Islamic thought today. ${ }^{129}$

The Maliki is the second school founded by Malik ibn Anas in Mecca. It differs from the other schools of law in that it includes the actions and statements of the Rashiduun Caliphs (the first four) as a part of its hadith tradition. In other words, it relies not just on the Quran and the words and 
deeds of the Prophet, but also the words and deeds of the four Orthodox Caliphs as the salaf, or righteous predecessors. It is the official school of Kuwait, Bahrain, and the United Arab Emirates, but its most widespread adherence is in Africa. The seat of Maliki learning was for centuries at the Grand Mosque in Khairoun in Tunisia. ${ }^{130}$

Muhammad ibn Idris al-Shafai, a student of Maliki's, founded the third school, which is prominent in Egypt, along the Red Sea littoral and in the Indian Ocean communities including Southeast Asia. The most obvious difference between al-Shafai and his teacher Maliki was that the former dropped the Rashiduun Caliphs as a source of authority in establishing sharia and focused instead on the hadith of the Prophet. ${ }^{131}$ The last school founded by Ahmad ibn Hanbal grew out of the Shafai tradition. In general terms, it is a literalist school that rejects delving into rationalist or philosophical interpretation. Interpretation is based on the literal texts of the Quran and hadith. ${ }^{132}$ Obviously, the differences are much more nuanced and detailed than these short explanations, but that is far less important than the fact that different schools existed and within the Sunni tradition from time to time they provided theological legitimacy for political aims that pitted Sunni groups against one another.

These four major schools only provide the most macro of perspectives on the divisions within the Sunni community. Accounting for more than a billion people from every imaginable political, economic, social and cultural environment, the political bandwidth represented in the Sunni tradition is by far the most varied. The issue of authority further complicates this situation. There is recognized 'Sunni authority' and in comparison to the Shi'a the structure of the trained clergy is relatively weak. The 'lay' component in Sunni Islam tends to be far more important, particularly in terms of the clergy, than in the structured Shi'a environment. There are structural similarities with certain forms of Christian Protestantism. A gifted speaker, capable of quoting Quranic scripture, can move from obscurity to prominence and significant financial resources relatively easily-all that is required is a following or wealthy backing. There is no formally structured clergy to prevent it except in those places where there is an alliance between the state and established religious authorities. Even then, individual Sunni preachers can still emerge as influential voices to those with whom the particular message resonates. ${ }^{133}$ 
In theory, anyone with a minbar (pulpit) or even a corner in a mosque has the potential to have a television program, be an Internet-star, inspire radical ideas and actions, or to become a leader in a violent jihadist organization themselves. Given the billion-plus number of Sunnis, there is every conceivable ideological stripe and persuasion. Some focus on the "greater jihad," the struggle for self-improvement and leading a more disciplined Muslim life. Some focus on the social welfare of the umma-clinics, hospitals, and the needy-and some focus on whom they see as the enemies of Islam. This list includes corrupt governments controlled or too heavily influenced by outside powers or on the outside powers as well. The message, the methods, and the results are not uniform. There is a consensus on only a few issues. There is often violent disagreement between groups and within groups about what constitutes the correct course of action not just vis-à-vis "oppressors," but about what a society should look like and how it should govern itself. Given this situation, it is hardly surprising that the Sunnis tend to generate all manner of splinter groups, including VEOs.

This reality also goes a long way to explain the difficulty in dealing with terrorism. In the age of global communication, there exists some borrowed overarching rhetoric for virtually any radical idea no matter how impractical or ludicrous, and some Muslims, like individuals in other religious groups, find like-minded radicals who provide mutual support. In the vast majority of cases, sympathizers prefer to provide verbal encouragement from a safe vantage point on the sidelines. In some cases, particularly in the oil-rich Arab Gulf, support translates to monetary donations. Only in a handful of cases does it turn into direct terrorist activities. Relative to the size of the Sunni umma or community, this latter group, while a serious problem, is tiny. In addition, when examined in detail the driving issue is almost always something that could be classified as local. There are exceptions but those are rare.

What does 'local' mean in this context? In examining radical jihadist movements, this analysis differentiates between locally generated issues and 'conflict on the periphery.' There will be a separate discussion of the latter. Locally generated conflict refers to conflict where the source lies within the Islamic community itself and where the Western or U.S. presence becomes an intertwined issue. In effect, for one reason or another, the U.S. or the West finds itself embroiled in what is in most cases an underlying centuries old conflict that has reemerged in one form or another. The reasons for involvement run the entire gamut from real vital national interests to colossal 
blunders related to naïve attempts at attempting to apply Western standards to non-Western cultures-the hard lessons of failed nation building.

To illustrate the role of a local conflict driving violently anti-American and anti-Western reactions, four examples illustrate the breadth of the problem-Iraq, Yemen, Afghanistan, and Indonesia. In Iraq, the U.S. fundamentally changed sides in a conflict that dates at least from the 3rd century C.E. In Yemen, for all Washington's protestations to the contrary, the U.S. has taken sides in a conflict of which dates from the 9th century. In the case of Afghanistan, no one can date the beginning of the internecine struggles but no one has imposed real central control on Afghanistan in its entire history. Indonesia is another case. The West and the United States finds itself embroiled in a multi-faceted conflict in which the rhetoric of Islam is used by competing political, socioeconomic and cultural traditions in a struggle for survival or dominance depending on one's point of view.

In each of these cases, Sunni Islam overlays a fractured political and cultural landscape in which the West for solid reasons of national interests or in some cases out of ignorance has taken sides. The group against which it finds itself allied merely adds the U.S., NATO or in the case of Indonesia, Australia to its list of targets. When for good reasons or bad, the West takes sides in a local conflict, it should be hardly surprising to find that the Western role becomes part of the opposition's narrative and a target for the poor man's most potent weapon-terrorism. In almost all of these conflicts, the driver behind the significant involvement of the West is a conception of the "national state" that may fit a Western model but has little or nothing to do with local perceptions of authority and identity. The West in general and the United States in particular is obsessed with the idea that lines on a map often drawn by colonial administrators constitute a 'state.' That notion is nonsense.

Iraq has been a battlefield between contending empires-East and West for millennia. The Islamic period is no different. The state arbitrarily created by Great Britain in 1920 has been no less fractured. As a result, the only governments that have functioned as states are authoritarian ruled through a mixture of political guile and ruthless repression. As Iraqi Prime Minister Nouri Maliki knows, real democracy is a prescription for chaos in which he would almost certainly lose power. Previous U.S. policy in Iraq has fostered local conflict that makes the U.S. a target. Washington followed the British lead with regard to Baghdad, in the aftermath of the 14 July 1958 coup. Like the British, the U.S. supported Sunni rule in the predominantly Shi'a 
state. Even with the rise of Qasim's government and its Communist allies, the U.S. continued to support a Sunni or secularist ruling alternative, hence the replacement of Qasim in the 1963 coup with a nationalist, pro-Nasserist government allied with the secularist Ba'th Party. The U.S. involvement and support was relatively low profile. The support for a Sunni Iraq continued and in fact intensified during the 1980s and the Iran-Iraq War because Saddam was politically preferable to Khomeini. ${ }^{134}$

Then, the invasion of Kuwait brought on a decade in which Washington opposed Saddam personally but not the ruling structure, which was Sunni-dominated. The events of $9 / 11$ provided the climate that gave political cover to the 2003 U.S. invasion in which the Bush administration turned the Iraq political structure on its head and backed it up with U.S. forces. The U.S. became the enemy of the once dominant Sunnis because it handed the government over to the Shi'as who had never ruled Iraq or for that matter Mesopotamia since 1638. The U.S. took sides in the centuries old conflict and paid with billions of dollars and almost 5,000 servicemen's lives. The U.S. became the enemy of Sunni Ba'thists, tribal elements, and nationalists of all stripes and created a training ground for international fighters under the banner of al-Qaeda in Iraq. The Sunnis, who were coopted during the "Surge," have now become the enemy of the new emerging Shi'a authoritarian order and have in large numbers joined hands with radicals calling themselves the Islamic State of Iraq and Syria or the Levant depending on the particular day. Now the governments in Baghdad and Damascus have turned to their old Russian friends for military equipment and training while Iran supports both as they mimic Persian empires of the past in their struggle for regional hegemony. In fact, had the U.S. stayed and attempted to force a real democratic state on Iraq, it would have then become the target of Shi'a groups. By exiting under the terms negotiated by the Bush administration, the Obama administration removed the U.S. military as a target and allowed the various political and sectarian groups in Iraq to go back to what they do best-fighting each other without excessive outside interference. The local conflict continues but the U.S. role has been greatly reduced.

In Yemen, since 1967, Washington has sided with a government based in Sana'a that is fundamentally a tribal-based, Zaydi-dominated regime. From 1967 to 1990, the socialist, pro-Soviet regime in the south was named a state supporter of terrorism. In 1990 at the end of the Cold War, the United States supported the unification of Yemen believing that the new Republic 
was in fact unified and would emerge as a stable democratic state. In fact, Yemen was no more a state than it ever had been; in 1994, the Sunni and secularist south attempted to separate from the Zaydi. A mix of southern military defectors, northern Zaydi troops, and Islamic tribalists conquered the south. From 1994 to 2012, the U.S. found itself on the side of the Zaydi dominated central government and increasingly opposed by Sunni Islamic fundamentalists, southern separatists, and increasingly radicalized domestic and foreign elements lumped together under the nom de guerre of AQAP. Here again a local conflict that predates the Islamic age in Yemen, coupled with U.S. involvement, provides the ideological and political catalyst for what will likely be years, if not decades of attempts by the more extreme radical Sunni elements of this group to attack U.S. targets and interests.

In Afghanistan, various political elements have been engaged in conflict at one level or another during the course of recorded history. In late 1970s, socialist and Communist elements with the support of the Soviet Union attempted to overturn the tribal order and impose a new secular state. The tribes resisted and then with massive U.S. support made the costs of continuing unacceptable to the Russians. Moscow decided that Afghanistan was simply not worth it. The very conservative, fundamentalist Sunni tribes that the U.S. had empowered through its Pakistani allies took control. They transformed Afghanistan into a haven for the pan-Islamic radicals of alQaeda who perpetrated 9/11.

In a matter of weeks, the U.S. sided with ethnic and Shi'a minorities and destroyed the radical Sunni regime and then became involved in an effort to transform Afghan society into a democratic, civil society with a functioning central government capable of controlling the country. These efforts have placed the West in the center of a local conflict that has stretched from time in memoriam. Western casualties exceed 2,000 dead and billions spent with little hope at this point in seeing a fundamental change in society. The risk of a transnational radical Sunni threat reemerging exists but the real issue is that the West finds itself as a player in an ongoing local or regional conflict that no one has won nor likely will. Opponents of the Karzai government, the warlords of the northern alliance, or the ethnic and sectarian minorities, which is a significant percentage of the population, opposed the centralization of power in the Karzai government that the U.S. and NATO supported. At the same time, the violent opposition to Kabul almost entirely comes 
from the fractious Sunni community, which uses Islam as the ideological justification in its struggle against its rivals in Kabul.

Former Afghan President Hamid Karzai had refused to sign an agreement allowing U.S. forces to remain in the country beyond the 2014 deadline. A Christian Science Monitor article commented, "In America's longest war, words like "victory" have long faded from the US military's lexicon," pointing out the U.S. policy at that time was focused on avoiding a civil war between presidential contenders. ${ }^{135}$ The stance on U.S. forces changed, however, after Ashraf Ghani, who supported the U.S. presence, was elected president and a deal was signed in early October 2014. Is the war in Afghanistan about Islam or is it a power struggle between rival political, economic, social and ethnic groups using Islam as ideological medium for rhetoric and legitimacy?

The situation in Indonesia provides another example of the heterogeneous nature of the Sunni community as well as the issue of intra-sectarian conflict. In Southeast Asia, a distinction is often made between two basic patterns or "intensities" of Islam-the syncretic Javanese form that blended Sufi mysticism and elements of Buddhism and what is referred to as santri Islam, i.e., those who took their Islamic identity and observances far more seriously. ${ }^{136}$ Islam was likely introduced into Indonesia at a very early stage but it only began to gain a significant foothold as it spread after 1200. Between the middle of the 13th century and the contemporary period, there have been no less than six identifiable "Sultanates" in what is now Indonesia. In fact, the oldest Sultanate of Ternate still exists and at its height dominated most of what is now eastern Indonesia and the southern Philippines. Islam arrived with the Indian Ocean trading culture of the early 13th century and was politically diverse. Different Islamic states emerged that were ethnically, culturally, and geographically separate-all Sunni but politically and religiously highly diverse. Real and perceived religious differences became a "powerful focus for peasant discontent in times of trouble."137

In fact, at the turn of the 20th century, Dutch colonial policy as set forth by Christian Snouck Hurgronje, the Advisor on Native Affairs in the Dutch East Indies, argued that Dutch paranoia about Islam came from "the Dutch colonial regime's ignorance of Islam." According to Snouck, the Dutch authorities:

fantasized that it was directed by a well-organized central authority similar to the papacy, a threatening inference for the largely Calvinist 
Dutch establishment ... Islam per se was not the enemy. The real danger lay in Islamic extremism either in the hands of local fanatics or foreign agents of a pan-Islamic conspiracy.

Aceh was the test case and the approaches with minor modifications were classic counter-insurgency-suppress the radicals and support the moderates. The war lasted 40 years until the Japanese occupation and when the Dutch returned in 1945, they made no effort to reoccupy Aceh. ${ }^{138}$ The Dutch decided that it was not worth it because after almost a half-century of effort, Aceh was still Aceh.

In the early 1950s, economic problems intensified the conflicts between the two Muslim factions, the reformists and the traditionalists, and the Communists as the major groups moved to create a mass, populist base. ${ }^{139}$ In the Indonesian political landscape under the Suharto regime (1965-1998), Islam was used as an ideological weapon to assist in the purge of leftists and Communists during the 1960s and 1970s, but all Islamic parties were forced to join an umbrella organization, the Party for Unity and Development (PPP) which was closely supervised by the government. Several Islamic groups resisted because the PPP was viewed as an instrument to assure central government control and Javanese political ascendency. ${ }^{140}$

In the aftermath of the collapse of the Suharto regime, a series of conflicts resulting from unresolved ethnic and communal problems that were suppressed by the Suharto security apparatus broke into the open. These conflicts illustrate well the idea of local grievance and the use of Islamic religious language as a means of expression. This also illustrates the problem of conflict on the Islamic periphery and local grievances acquiring the support and the language of pan-Islamic violent jihad as well as the dispersed nature of Sunni violence that makes it so difficult to control. Between 1996 and 2005, there were outbreaks of serious violence in Kalimantan (1996-2001), Maluku (1999-2004), and Central Sulawesi (1997-2007). In every case, these outbreaks were based in ethnic differences exacerbated by Christian and Muslim proselytizing and economic competition. Weakness in the central government and political infighting prevented any semblance of coordinated response, and in some cases, the security services encouraged the violence to discredit the central government. Source and leadership conflict had root in narrow local issues. They accounted for over 9,000 deaths-Muslims, Christians, Hindus, and even animist headhunters. ${ }^{141}$ 
Two of these conflicts, although clearly homegrown, attracted Islamic militias from other areas of Indonesia and aggravated the situation. Some of the militias viewed their role as coming to the aid of Muslims under threat and others had more grandiose schemes. Jemaah Islamiyah (JI) saw the Sulawesi conflict as an opportunity to establish an Islamic "enclave" as a precursor to an "Islamic state." JI's involvement brought support from the Arab Gulf States and particularly private funding from Saudi Arabia. Many of the attacks represented an attempt to embarrass and undermine the government, which they did not view as Islamic enough. ${ }^{142}$

This reaction represented a kind of political revenge for the suppression of the Darul Islam movement under Sukarno and Suharto. The most radical leaders were of non-Indonesian descent and had fought with U.S. support against the Soviets in the Afghan War. Laskar Jihad had similar roots in the Afghan struggle, similar funding, and similar leadership. They also had direct ties to Osama bin Laden and many of the Malays and Filipinos who would return from Afghanistan. The two organizations were in competition for the leadership role of the radical jihadist movement. At Christmas 2000, JI staged 300 bomb attacks in 19 Indonesian cities, a campaign that culminated in the 2002 Bali attacks. In the aftermath of the bombings and the crackdown on JI, the evidence suggested that JI certainly had contacts and received some funding from al-Qaeda but that the latter had no operational control. They shared many of the same ideas but shared no real structure or organizational ties. ${ }^{143}$

Underlying this relative open-mindedness on the part of the majority are special cases and problems. Following several full-scale rebellions, the province of Aceh on the far western edge of the island of Sumatra has a semiautonomous status where sharia law is the recognized legal code. Fiercely independent, it has been the scene of revolts against outside rule whether the Dutch in the colonial period or from Jakarta after independence. The mainstream of the Free Aceh Movement (Gerakan Aceh Merdeka) never had ties with al-Qaeda and has focused on economic and social development. It has a nationalist Islamist agenda not a pan-Islamic dream. ${ }^{144}$ Aceh separatist status is a source of concern in Jakarta because other groups are in a position to claim similar status and religion-Islam or in the case of Timor, Christianity-might well provide the language. ${ }^{145}$

The syncretic approach of the Indonesian government to religion since independence has provided an ideological rallying point for those that 
oppose the political, economic, and social order that rules the country, an order that the West in particular has largely supported for almost 70 years. Thus those small radical Islamic groups that oppose the Indonesian political structures also see those supporting it as their enemy. They view the West and particularly Australian and U.S. influence as obstacles preventing the realization of their political agenda. It is this perception of the West as interfering in a local conflict and tipping the scales in favor of the Indonesian government that in their minds makes Westerners legitimate targets for attacks.

There are more examples but these four provide an indication not only of the diversity of Sunni beliefs, but also underscore the lack of any real broad central authority in Sunni Islam. From the point of view of violent jihadist organizations, virtually all of them, despite their rhetoric at times, have their roots in local or at least regional conflicts. In addition, most of these conflicts are so fundamental to the political, economic, social and cultural structure of a particular area that Islam provides the language for ideological legitimacy or superiority more than it does the basic motivation for conflict. Islam, particularly Sunni Islam, spread because of its flexibility and adaptability; thus, it merely provided a new or different prism through which differences that already existed were refracted. It did not eliminate the differences and replace them with a necessary uniform ideological structure.

This is good news and bad news with respect to the challenges presented by radical violent jihadist Sunni organizations. Elements within the Islamic community may try to enforce various orthodoxies, but the potential for anyone succeeding in establishing a monolithic Sunni orthodoxy is virtually non-existent. Sunni Islam is a cacophony of voices, providing their own interpretation of Sunni orthodoxy. Therefore, the billion-plus Sunnis in the world pose neither an overt nor a covert monolithic, totalitarian threat to anyone, including themselves. Simplistic Cold War narratives of monolithic Communism were not only false, they were illogical and naïv; the same is true of simplistic monolithic views of Islam in general and Sunni Islam in particular. That is the good news.

From the standpoint of terrorism and political instability, the bad news is that Sunni Islam is more fractured in most respects than its Shi'a counterpart. In most cases the motivation for violent jihadist activities results from local or regional conflicts. Given more than a billion people and innumerable conflicts, even a very small number of VEOs are a major and likely 
unsolvable problem. Given the lack of disciplined political or theological control-any layperson with little or no religious training from the Sunni tradition can attract a radical following and become a potential threat (Bin Laden, Zawahiri, Zarqawi, et cetera). Taking sides in one of those conflicts, no matter how well-meaning, earns the interloper the status as an outsider, particularly a Western outsider and especially an American one. In the minds of the opposition, the interloper is a combatant and thus a target.

When the Sunni community is involved, it might be better to look at the deeper context of given situations to determine if local conflicts really do warrant intervention to protect U.S. national interests. In Iraq for example, the U.S. unseated Sunni dominance and they retaliated. During the surge, the U.S. then coopted them against the wishes of the Washington-installed Shi'a dominated government, and then abandoned them again to fight it out with an increasingly authoritarian Shi'a government. A cynic might say that Iraq was far more trouble than it was worth and so the U.S. decided to let them settle it-it removed the U.S. from combatant status and the new focus of Sunni-based Iraqi terrorism became the Maliki regime.

In Afghanistan, the U.S. demonstrated two things: its ability to almost effortlessly overthrow and destroy a central government using its internal opposition, aircraft, and SOF, and secondly, its almost total inability to build a viable truly functional national state. Both are due in no small part to the fractured nature of Afghanistan and how that is reflected in the local Sunni Islamic community. As the Afghan government contemplates the reality of survival without large-scale U.S. military support, they admit that violence will continue because "the insurgency is too varied and localized." The issue is not Islam, it is the local situation with the Islam overlay. ${ }^{146}$ In Yemen, the fact that radical jihadists have found purpose among Sunni tribal and societal elements in the coastal areas and the east should come as no surprise. From the perspective of many Sunnis, the U.S. has aligned itself with a Zaydi, military, tribal regime for half a century, including an invasion and conquest of the South in 1994. By doing so, the U.S. became the enemy of the southern Yemeni identity and the ally of Sunni Yemen's enemy, the tribal Zaydi north. In Indonesia, from the Suharto regime to the present Republic, the U.S. and the West has supported the government in opposing an Islamic state. Radical elements see policy from Jakarta as a direct result of Western influence; thus, the West has become a legitimate target in the eyes of some violent groups. 
The bottom line is when U.S. interests dictate inadvertent or intentional involvement in a local conflict, particularly conflicts in which Washington finds itself opposing the perceived interests of the Sunnis in a particular region, then the rise of violent extremists groups is going to be a problem. The nature of the Sunni umma only magnifies the problem because of the lack of a recognized central religious and political authority. The lay component of Sunni Islam opens the door for radical political and ideological entrepreneurs and the sheer size and breadth of the community means that even an extremely small, almost infinitesimal fraction of the whole can be a serious problem. In Sunni Islam, the critical issues are the violent non-state actors.

\section{Shi'ism, Authority, and "Terror"}

In The Shi'a Revival, Vali Nasr argues, "In the coming years, Shias and Sunnis will compete over power first in Iraq but ultimately across the entire region." He goes to some lengths to explain the conflict and its radicalizing effect, particularly on Sunnis. At the same time Nasr makes pronouncements about the "one Islamic reality." This is symptomatic of the general reluctance on the part of Muslims in general and Shi'a Muslims in particular to take a consistent position on the issue of unity or tawhid. Even a Shi'a author who recognizes the differences and the fundamental conflicts based ethnicity, sectarianism, and culture feels compelled to discuss all the problems and then insist that there is "one Islamic reality." 147

As the second largest sectarian group, Shi' ism is highly diverse despite their generally far more structured hierarchy than the Sunnis. There are also the underlying three original forms of Shi'ism-Twelver, Sevener, and Fiver-though only two of the three, the Twelvers and Fivers, have a structure that directly affects political stability and security issues. The Sevener concentrations are relatively small and are spread from North Africa to Yemen to India. Sevener, or Ismaili Shi'ism, has nowhere near the political and ideological impact that it once did in the time of the Fatimids in Egypt, the Qarmatis in Bahrain, or Hasan al-Sabbah and his New Order, the Assassins of Alamut. Fiver, or Zaydi Shi' ism, is now the second largest of the major Shi'a sects and has significant impact on the regional Islamic politics and security issues. Not because of doctrinal issues or even because of their militancy, but rather because in Yemen, Zaydi sectarianism dominates the Republic of Yemen government and is attempting to rule the Sunnis of 
the littoral and eastern areas of Yemen. This has radicalized the politics of Yemen, causing it to spill over into the region and globally. It is the Twelver group that constitutes the real political challenge to total Sunni domination of the umma and in particular the significantly expanded influence of Iran since 2001 in the region. This section will primarily focus on the Twelvers or Jafaris but it will also touch on the Fivers and Seveners as required.

First, a slightly more detailed primer on contemporary Shi'a is in order. The premise of this study is that theology provides the language or terms of expression for more concrete geopolitical, socioeconomic, and cultural conflicts; however, theological differences and arguments have a far more practical impact on those conflicts. The Sunni community is not only far larger than the Shi'a but also far more fractured in the sense that religious and political authority among the Sunnis tends to function in traditionally separate channels, i.e., sulta, or institutionalized government power, rests with authority outside of supporting or criticizing rulers as good or bad in terms of policy and behavior. There is no direct role for the clergy in political rule. Hence, issues tend to be local in nature following the pattern of more fractured political rule. ${ }^{148}$

In Shi'ism, particularly Jafari Shi' ism, there is an institutionalized political role for the clergy and in theory a direct link through the Alid to Ali bin Abi Talib, the person that the Shi'a believe was the legitimate successor of the Prophet. ${ }^{149}$ This provides the Twelver Shi'a clergy with an undisputed political status despite the fact that there are serious debates within Shi' ism about the exact status. The imams of Shi'a Islam (Twelve, Seven or Five depending on a person's persuasion) were the representatives of God and the Prophet Muhammad on earth. After the occultation of the last imam, senior members of the clergy become the deputies of the Imam and finally, the Shadow of God on Earth. ${ }^{150}$ In Shi'ism, there has always been a shared political role for the clergy since the imams embodied, in theory, both temporal and religious authority. ${ }^{151}$ In practice it has not always worked that way because the imams or their representatives have had to share power with sources of authority, but it has always been an argument about the limits of the authority, not whether or not it existed.

Particularly in Twelver Shi'a, deciding upon the "representative" or "deputy" of the imam has been a responsibility that is not taken lightly. Therefore, unlike the Sunnis with the fractious role of 'lay clergy', the Shi'a have more or less rigorous standards and rankings within the ulema. They 
also have specific centers of learning, particularly Najaf in Iraq and Qum in Iran, where the senior theologians are broadly recognized as religious authorities. These factors, the historical link to politics, the standards of religious learning, and the clerical rankings tend to give Shi' ism greater vertical cohesion than exists among the Sunnis. In other words, Ayatollah Khomeini with his religious training, interpretation of Iran's historical condition, scholarly intellect, and skills as a formidable politician surpasses the Sunnis clergy. Even Khamenei (the current Supreme leader) has a religious education that is superior to lay-Sunni clergy in the ilk of Bin Laden, Zawahiri, et cetera, and equal or superior to many clerics in the various Sunni ulema. From a Shi'a point of view, referring to someone like Bin Laden as imam is laughable. Shi' ism also inherited the Persian penchant for hierarchy and structure. Thus Shi' ism, particularly Twelver Shi' ism, tends to be much more hierarchal with a tradition of direct political involvement. ${ }^{152}$

In contemporary terms, this does not mean that Shi'ism is doctrinally or politically uniform. There is a rivalry between the Shi'a schools in Iraq and Iran. Those in Najaf and Karbala view the Iranian schools at Qum as relative upstarts. The political philosophies are different as well. Nevertheless, among the Twelvers there tends to be more vertical cohesion and more structure with reference to religious and political legitimacy. The Twelver Shi'a of Lebanon represented by Hezbollah recognizes the religious authority of Qum. Politically, Hezbollah makes decisions based not on 'orders' from Tehran but rather on their own local political situation, taking into account that Iranian funding and support is important. Hezbollah's involvement in Syria is more a manifestation of the threat posed by a Sunni victory that would cut the link of support through controlled Damascus to Tehran and less a reflection of Shi'a solidarity with the Alawite regime. ${ }^{153}$

The West and the Sunni Arab states attempt to use aid to obtain support in Lebanon among the Sunnis and the Christians, but both groups lack the same type of ideological authority that exists because of Hezbollah's attachment to Qum. The intent and methodology are the same, but the results are not because the structured legitimacy is missing. In Syria, Iran provides critical financial aid and political support to the Alawite regime, and critical ideological legitimacy. Sunni Muslims and some Shi'a Muslims consider Alawites to be non-Muslims or apostates. The Syrian constitution requires the president to be Muslim. The Iranian government has supported the argument made by some Lebanese Shi'a clerics as early as the 19th century that 
the Alawites are a legitimate offshoot of Twelver Shi'ism. ${ }^{154}$ This theologically debatable ruling is obviously political and critical to both Damascus and Tehran. This does not mean that Tehran dictates policy in Damascus, only that it has enormous influence-at least for the time being.

In Syria and Lebanon, the relationship of the Alawites and the Druze to the Shi'a is often misunderstood. Iranian mullahs' declaration that the Alawites are a branch of Twelver Shi' ism is based on political not theological considerations. Theologically the Alawites borrow traditions from both the Sevener and Twelver Shi'a traditions. While they revere Imam Ali ibn Abi Talib as the legitimate Caliph after the Prophet, they also celebrate Christian, Zoroastrian, pagan Syrian festivals, and "secret" rites. Prior to the French Mandate (1919-1945) in Syria and Lebanon, the Alawites were called Nusairis, a name derived from their first theologian Muhammad ibn Nusair, who in 847 CE declared himself the bab (gate) to the 10th Shi'a Imam. ${ }^{155}$ During the French Mandate, their presence in the military and police provided them with a powerbase. Many embraced the secular message of the Ba'th Party and by 1970 under Hafez al-Assad the Alawites took effective control of the Syrian state. ${ }^{156}$ Oddly enough, for much of their history, the Alawites had opposed the creation of a national state in Syria because they believed it would only reinforce the domination of wealthy Sunni landowners. During the Mandate period, they used military power to turn the tables on the Sunni majority and secular Ba'thism to provide the ideological justification for rule. ${ }^{157}$ Other than to state that the President of the republic must be a Muslim, Islam is not mentioned in the Constitution of 1973 because of Alawite beliefs and the Sunni majority. ${ }^{158}$

The Druze community represents another group with a connection to Shi'ism but a divergent theology. The Druze are an 11th century offshoot of Ismaili or Sevener Shi'a Islam. The sect originated during the reign of Fatimid Caliph Abu Ali Mansur Tariqu al-Hakim in late 10th century Cairo. In the simplest terms, Hakim believed that he was semi-divine, as did the Druze. They were considered heretics and often persecuted by Muslim authorities. At the same time, they had a reputation as first class soldiers and often served rulers in Damascus in that capacity. In modern Syria, they precipitated revolts and coups against first the French and then various Syrian governments. In the contemporary era, they managed to gain almost complete autonomy within Lebanon despite the 1977 assassination of their leader Kamal Jumblatt by the Syrian intelligence service. Kamal's son Walid 
Jumblatt became the political leader and maintained an uneasy alliance with the Syrians while performing a political balancing act among the various political parties in Lebanon. In the current conflict in Syria, while the Druze community of 700,000 initially maintained its neutrality, it has increasingly begun to side with Assad and the government. This is being driven by fear of a Sunni Islamist victory in which the Druze, as heretics, would become the target if Islamist Sunnis gained power. ${ }^{159}$ To further confuse the situation, more than 100,000 Druze, who have close ties to the Druze in Lebanon and Syria, live in Israel and many serve in the Israeli Defense Forces (IDF) and two serve in the Israeli Knesset. ${ }^{160}$

In Afghanistan, significant opposition to the Taliban government prior to 2001 came from Iran in the form of support for the Shi'a minority. Since 2001, the mutual antipathy of the U.S. and Iran toward radical Sunni movements and regimes has moved from the struggle against the Taliban government in Afghanistan to open discussions of shared interests in Afghanistan and the Levant. From Washington's perspective, it is difficult to see Iranian influence in Afghanistan as worse than the radical Taliban state. This is also reflected in the evolution of U.S. policy where despite the persistence of the nuclear issue, Washington and Tehran share an even greater antipathy for Sunni radicals, including the Taliban, Islamic State in Iraq, and Syria. ${ }^{161}$ Given the departure of U.S. and NATO regular troops, and the power-sharing arrangement between Karzai's successors, there is potential for continued political infighting. There is also increased risk of fall-out from corruption investigations, including Karzai's role in the recent election deadlock, and efforts on the part of the Karzai family, some of it U.S.-based, to maintain power and influence. ${ }^{162}$ After 13 years and billions of dollars in aid, the current Afghan government requires continued life-support and the U.S. looks around for longer term regional allies against the return of a regime receptive to radical pan-Islamic influences. Even a partnership with the old Indo-Iranian alliance in support of the opposition to Haqqani and Pakistani-backed radical Sunni elements begin to look more attractive. ${ }^{163}$ As the U.S. pushes India to have a bigger role, India pushes its ties with Iran as the best way of counterbalancing Pakistan and the Taliban-an interesting conundrum for Washington. ${ }^{164}$

With regard to Saddam Hussein and Iraq, if the U.S. views expanded Iranian influence in the Gulf as a problem, then it would appear that the destruction of the Saddamist and Sunni dominated state was a strategic mistake with long-term implications. However, the current relationship between 
Baghdad and Tehran, although close, is fraught with potential problems. The ruling regime in Tehran subscribes to an interpretation of Shi'a Islamic political theory-wilayat-e fiqh-that disagrees with the dominant Iraqi interpretation. In the Iranian, or Khomeini's version, wilayat-e figh specifies a direct role for the clergy in ruling the state. In the Iraqi version, of which Ayatollah Sistani is the most powerful advocate, clerics from Najaf see a quietist role for the clergy focused on indirect political influence, advice on what is religiously acceptable, and only in extreme cases a direct role in politics. Given Sistani's poor health, a clash is in offing between Iranian backed and traditional Iraqi clerics. ${ }^{165}$ The implementation of an Iranian style system would seriously increase hostility from the Kurds and Sunnis, but it would also be a challenge to the increasingly authoritarian government. Khomeini style clerical rule would be no more acceptable to the current government than any other system that would diminish the current government's political power.

These heterogeneous attributes of Shi'ism represent fracturing at the leadership level. It is about whom or what kind of system should dominate an already fundamentally hierarchical system. There are fissures in Shi'a Islam but not on the scale of those among the Sunnis. ${ }^{166}$ As a result, the tendency to lump states where Shi' ism is dominant or has a large supporting political organization into the same 'terrorist' category as the various Sunni groups is both a tactical and a strategic mistake. With the Sunnis, the problem tends to be small splinter groups striking out against Sunni political regimes as well as the West. Radical Sunni aims are often politically impractical, theologically simplistic, and confused. What the West classifies as terrorism among the Shi'a is almost always the intentional tactic or the broader strategy of an established state or political party. It is rarely the result of splinter groups. ${ }^{167}$

In virtually every situation, the activities of "terrorists" in the Shi'a tradition is in fact part of an identifiable state or party strategy. It lacks the disconnected randomness of the violent Sunni groups. This is good and bad news. On the one hand, the ultimate source of the policy driving the terrorist activity is usually identifiable and on the other, it has a greater tendency to be a part of a considered, thought-out strategy with some kind of state backing. The problem is there is a tendency to see the Iranians behind every Shi'a related conflict. In many cases, the Iranians are involved at some level, but most often, it is a case of the Iranians attempting to take advantage of 
a preexisting problem. The Iranians may have influence to varying degrees over non-Iranian Shi'a groups, but it is not control.

Hassan Nasrallah and Hezbollah in Lebanon take Iranian money and support, but Hezbollah usually pursues policies because they are deemed in Hezbollah's interests, not necessarily Tehran's. Frictions with the Lebanese Sunnis, the Christians and others may serve Iranian interests, but they exist because of Hezbollah's view of its own interests. ${ }^{168}$ Syria is another case in point. Damascus has the backing of Tehran but the slaughter of civilians in its bloody attempt to suppress the current rebellion with state terrorism has to do with Assad's view of the regime's interests. In fact, the brutality of the Assad regime has created a problem for Iran in the broader Islamic world. Iraq is another case in which Iranian support has been a boon to the Shi'a as they established a post-Saddam Shi'a dominated state. It was also in Iran's interests to see that happen.

The Maliki government attempted to extend its authoritarian grip and to gain real control of Iraq but that has now collapsed into chaos. The current Iraqi situation reflects the historical context of the Levant and particularly the artificial colonial creations of Syria and Iraq. Opponents of the Maliki regime, including the Kurds, the Sunnis, and now some Shi'a, have attempted to unseat the Iraqi leader. Iran is supporting Maliki for now and is directly involved in propping up what is left of the government control. ${ }^{169}$ For Iran, a fractured, partitioned Iraq under siege is far preferable to the more nationalistic political groups that might come to power. Iran will shift its support among political groups with the goal of keeping Iraq divided and weak, and it will use covert means, including Islamic Revolutionary Guards Corps units, to accomplish those goals, including targeted terrorism, as a part of a more coherent broader strategy. For Iran, the policy focus is Tehran's interests, not a new pan-Islamic order. Ironically, Maliki's second strongest supporterthe U.S.-is executing a policy in Iraq that is surprisingly aligned with that of Tehran. Both the U.S. and Iran fear a radical Sunni Islamist regime in Iraq. ${ }^{170}$ Iran does not want to see a unified, strong Iraq capable of defending its own interests in the region be it Sunni or Shi'a. Thus the current collapse of the Iraqi state has strategic benefits and complicated security problems for both the U.S. and Iran.

In Bahrain and Yemen the level of Iranian influence and involvement in the protest movement against the Al Khalifa or within the Huthi revolt should not be exaggerated. Would Iran like to see a Shi'a state in Bahrain, 
unrest in the Eastern Province of Saudi Arabia, or an insurgency in Asir and Najran? Absolutely. Are these problems a strategic threat to either Al Khalifa rule or Saudi security? Perhaps to some limited degree. Mostly, they constitute an ongoing nuisance, but Iran will do what it can to keep the problems festering because it is in their interests to do so. ${ }^{171}$

Viewing Iran as the puppeteer in these issues ascribes too much capability to the Iranian Republic, and it serves to transfer the blame from the root problems and issues to a malevolent, Shi'a monolith that does not exist. Iranian policy is to take advantage of Gulf Arab and U.S. problems in the region - that is what they are trying to do and both the Arabs and the U.S. are responding in kind. Political agitation, insurgency, and terrorism in the Shi'a tradition tends to be the function of state or political party policy, which is a very different proposition than the splinter group violence found among the Sunnis. The U.S. response requires a far more sophisticated evaluation of motivations and potential options to deal with it than the global "search and destroy" methods being employed against the Sunni radical groups.

\section{The Pan-Islamic Idea and Cold Hard Light of Reality}

To this point, the discussion has focused on issues of radicalism and terror as they relate to the larger sectarian groups with the Islamic umma. This argument not only rejects the notion that Islam or Islamic radicalism is monolithic, but it also rejects the notion that monolithic authority, belief, and structure exist with the larger subdivisions of the Islamic community. This does not mean that elements in the Islamic umma do not "imagine" an esoteric state of unity, the illusionary Caliphate of the mind, just as nationalists without a state have imagined a state, but it means that pan-Islamic goals like the broad pan-national goals of pan-Arabism have eluded realization. ${ }^{172}$ Muslims believe in one God and the Quran but beyond that the arguments begin. In this sense, they are very similar to the other two great monotheistic religions (Christianity and Judaism). The discussion of 'Pan-Islamic' movements is next.

Throughout the course of Islamic history, Pan-Islamic movements have evolved that represent the chasm between the theory of a united community with a uniform set of beliefs, tenets, and symbols and the divided, fractured reality of the Islamic umma. As previously discussed, division and conflict afflicted the Islamic community from the very beginning. As a result, a steady procession of movements have arisen that proposed to end 
the divisiveness and return the community to its theoretical perfect state of unity. ${ }^{173}$ These movements have been so prolific in the last 1,500 years that it would be impossible to list, much less discuss them all; therefore this study proposes to briefly examine just two of the most recent-Khomeini's Pan-Islamic ideas and those of Bin Laden and Zawahiri. Both provide good examples of the problems associated with Pan-Islamic movements in general, and more specifically they underscore the fallacy inherit in any view of Islam as monolithic.

In the last 25 years, the focus on the Twelver Shi'a (Jafari) aspect of the state and system that Khomeini created has largely obscured the Pan-Islamic nature of his thought and intent. At some point during his exile in Iraq (19651978) Khomeini's political theory transformed from that of a traditional Iranian Shi'a cleric and nationalist opposing the Shah and foreign and secular influence in Iran, to that of a pan-Islamic movement with a message and a role that transcended Iranian issues and Twelver Shi' ism. In this system, Khomeini was the "rightly guided one." He saw his movement as a model for the expansion of a new Islamic order that would rid the Muslim world of what he viewed as corrupt rulers and foreign influence. After Iran, the revolution was to move to the Arab States of the Gulf, then the Arab Middle East, and ultimately the entire Islamic community. Khomeini called for an Islamic world that was "neither east nor west but Islamic."174

After the collapse of the Shah's regime in 1979, the broader revolutionary goals focused quite naturally on Islamic states with large Twelver Shi'a populations and particularly the Arab states of the Gulf region. Inciting the Shi'a in southern Iraq to overthrow the secularist Ba'thist regime in Baghdad was a primary goal. It was not only politically driven by his reaction to 13 years in Iraq where Ba'thism and repression were undermining the Shi'a community, but also by his personal loathing for Saddam Hussein. Saddam was the chief of Iraqi security and Khomeini lived under his thumb. The ayatollah also wanted to overthrow Arab monarchs and emirs of the Gulf, particularly Saudi Arabia. To this end, the Iranians sponsored attempts to undermine the governments of Bahrain and Kuwait and to foment revolt among the Shi'a in the oil rich Eastern Province of Saudi Arabia.

Khomeini convinced himself that his success in Iran in overthrowing the Shah would translate into similar movements in the rest of the Muslim world. He believed that the timing of his Islamic and anti-Western message would overcome any sectarian issues related to Twelver Shi'ism. In this 
regard, Khomeini underestimated the degree to which the combination of a Persian-Shi'a identity is despised in the region and particularly among the Sunni Gulf Arab states. While Khomeini was capable of astutely handling the political situation in Iran, the overshadowing reality of Arab versus Iranian political interests, cultural differences, and fundamental ideological problem of being Shi'a and Persian has been insurmountable.

Initially the Iranian Revolution, to a significant degree, constituted a middle class and intelligentsia revolt against the monarchy couched in terms of Twelver Shi' ism - "the Quran, sacred law, and the twelve imams" to attract popular support. ${ }^{175}$ Ultimately, Khomeini's Islamist populist message and the Revolutionary Guard enabled him to hijack the revolution. The more the Iranians attempted to export their revolution, the more resistance increased; in fact, it resonated only among other communities of Twelver Shi'a in the region. Interests and political goals drove the differences but sectarian Islamic issues ideologically legitimized Gulf and Sunni opposition to Tehran.

Support for Khomeini's pan-Islamic ideological goals in the Arab Gulf was either insignificant, ineffective, or both. Khomeini did more for Arab unity in the Gulf than the formation of the Gulf Cooperation Council was to a significant degree a reaction to the threat posed by Khomeini's ideas and Iranian subversion. ${ }^{176}$ As one analyst stated, "If the 1979 Iranian revolution motivated gulf rulers to act, the 1980 Iran-Iraq War provided them with the excuse to allay whatever mistrusts they may have had, to finally act collectively." 177 In addition, Iranian efforts resulted in closer ties between the Arab states of the region and the United States. It also strongly influenced Saddam Hussein's decision to take personal control in Iraq in 1979 and to launch a preemptive invasion of Iran that resulted in the debilitating IranIraq War of 1980-1988.

Until 2003, the only real success that Iran could claim would be the growth of Hezbollah as a military and political force in Lebanon and close ties to Alawite Syria. Without the U.S. invasion of 2003, Iran's influence in Iraq would likely have remained limited. Khomeini's attempt at creating a pan-Islamic movement failed because of the divided political and cultural reality of the Islamic community. Twelver Shi'ism and sectarian differences provided the ideological language to justify political and cultural opposition in most of the Arab world and Southwest Asia to the message emanating from Iran. ${ }^{178}$ 
The pan-Islamic goals, if not the message, of al-Qaeda have also been lost in the fractured political and cultural landscape of the Islamic world. AlQaeda has become an anti-American/anti-Western 'brand' for groups with local or at best regional political, economic, and social grievances. Whether the original theories or ideas driving al-Qaeda came from Bin Laden or Zawahiri is of lesser importance. The issue for examination here is the conception of al-Qaeda. Initially, Bin Laden was a disciple of Abdullah Azzam, the charismatic Palestinian Sunni cleric committed to rolling back nonMuslim intrusions into the Muslim world. This fit the motif of the Afghan war against the Soviets perfectly. His activities in Afghanistan during the war against the Soviets were known to and endorsed by the governments of Saudi Arabia, Pakistan, and even the United States-the Cold War made strange bedfellows. ${ }^{179}$ However, he did not embrace "regime change" in the Muslim world. It was Zawahiri's influence that convinced Bin Laden to embrace this new "expansive view of jihad" and the concept of takfir, or labeling other Muslims as apostates. ${ }^{180}$

Its supporters saw it as the core and beginning point for a new Islamic order, an all-encompassing modern Caliphate that would sweep away the corrupt regimes ruling the Islamic world and remove foreign influence and involvement. Saudi Arabia's rejection of Bin Laden's simplistic faith in an Afghan-style jihad to confront Saddam Hussein in 1990 formed a catalyst. His invective stated that, "The (Saudi) regime betrayed the Umma and joined the Kufr, assisting them against Muslims" constituted to the point of no return. ${ }^{181}$ It was pan-Islamic. Its roots differed from Khomeini because they were Sunni in origin not Shi'a. While Shi'a Islam is heterogeneous it is based on a more hierarchical theological and clerical arrangement. Shi'a leadership has real institutional authority and is reflected in the political and social structure. In the case of the Sunnis, authority is diffused and leadership is less institutionalized. As Stephen Humphreys put it:

Caliphs [or rulers] might help the Community of Believers live in accordance with the divine commandments, and they symbolized its ideal unity, but in the final analysis the community was responsible for its own salvation, for knowing and maintaining the truth that God had revealed to it. ${ }^{182}$ 
Thus, the individual could define the legitimate community as broadly or narrowly as desired. It is a fertile environment for the growth and expansion and the emergence of radical splinter organizations.

The Sunni origins of al-Qaeda as well as other Sunni based radical splinter groups increases the complexity of combating it. The West, particularly the United States, has a preconceived view of the world as a collection of national states with centralized political power. This simply does not exist in areas where VEOs prosper the most. Yemen and Afghanistan have never been traditional national states and Syria and Iraq have ceased to be national states. The Sahel in North Africa is a geographic term that defies political organization. In fact, globally, the national-state that controls its own territory is becoming more of an endangered species. Increasingly, U.S. policy is based on finding or supporting national political or governmental centers of gravity that do not exist.

In these environments, there is always a grievance to exploit and a potential VEO. This is particularly true in areas where the ideological roots are in the Sunni tradition. The fractured nature of societies and the stresses inherent in them at all levels creates local and regional conflict. The ideological flexibility and lack of structural authority in Sunni Islam provides the legitimacy that makes Sunni-based radical movements and terrorist groups so difficult to combat. The strange life and metamorphosis of al-Qaeda as conceived by Ayman Zawahiri and to a lesser degree Osama bin Laden underscores the problem. Al-Qaeda, a splinter group among other radical Sunni-based splinter groups, was conceived as the vehicle for the creation of a global pan-Islamic Caliphate. Even if one forgets for the moment that no such institution has ever existed; the idea is simply implausible. It was not as some argue-terrorism for terrorism sake; there were the political, economic, and social goals of a 'just' Islamic Caliphate.

Even at the height of its success-on 9/11-al-Qaeda sparked controversy within the umma and severe criticism because its momentary success had resulted in the destruction of the only truly Islamic state in the Islamic world, Taliban-ruled Afghanistan. The original idea to provoke a U.S. invasion and then bleed the Americans failed. The Northern Alliance supported by a handful of CIA and SOF personnel and airpower destroyed the Taliban regime and al-Qaeda's base of operations. Subsequent attacks in Spain, the United Kingdom, Bali and other attempts to strike the U.S. were less the 
result of an al-Qaeda command and control structure than they were local operations inspired by the success of $9 / 11$.

Al-Qaeda became the desirable brand or cachet because of 9/11 and because of the media and U.S. policy frenzy related to anything associated with al-Qaeda. The name alone gained notoriety and added legitimacy no matter how tangential the actual relationship with the original al-Qaeda organization and leadership. During the Cold War, insurgencies and resistance movements adopted similar 'brands' ('popular fronts' and 'liberation fronts'). The difference was that the 'fronts' often had real state backers while the current VEOs do not. In the West, there is a propensity to transfer the 50 -year-old, learned paradigm of the Cold War insurgency with its centralized sponsor to a similar view of the Islamic radicalism. After the collapse in Afghanistan, no state backer existed for the Muslim VEOs. The VEOs existed as symbiotic or parasitic elements within local and regional conflicts. To be sure, all were anti-Western and anti-American, but their real legitimacy came from their position vis-à-vis local issues and grievances.

The fractured nature of the Islamic community prevents pan-Islamic movements from gaining real political traction. Khomeini's attempt at creating a pan-Islamic movement failed not only because of the competing interests within the Islamic community but also because the sectarian divide undermined virtually any appeal among Sunnis for alignment with a Twelver Shi'a Ayatollah. Khomeini and his successors established relationships that extended to other Shi'a and even some Sunni groups but each pursued its own interests. In addition, the hierarchical structure of Twelver Shi'a required a level of discipline that simply did not exist in Sunni Islam.

In examining Sunni-based attempts to establish a pan-Islamic movement, the experience of al-Qaeda underscores the problem associated with establishing even limited control much less a mass movement. Islam provides a common language for the movements but local political and cultural issues drive the policies; thus, to deal with the threat requires a focus on the local and regional drivers more than the particular version of Islamic ideology. The difficulty in dealing with jihadist movements is not the unified, monolithic threat posed by radical pan-Islamic movements, but rather just the opposite. It is the heterogeneity of the threat that is the greatest challengethe fact that it more often flows from regional and local issues. 


\section{Summary}

This snapshot of contemporary issues in Islam provides a comparison at the macro level between the contemporary Shi'a, Sunni, and pan-Islamic traditions and violence as a tool. The examination rejects the idea that terrorism can be understood or countered through a monolithic Islamic context, i.e., the idea that violent radicalism is part of a unified Islamic structure or set of beliefs. Instead, this chapter argues that VEOs must be understood within the context of local or regional geopolitical, socioeconomic and cultural conflicts. Generalities simply distort an understanding of the problem. It is not Muslims or Islam in general terms that creates the environment for radical violence but rather the clash of local and regional interests within the Islamic community. Islam provides the language-the rhetoric-of the conflict but it is not the catalyst.

Within the Islamic community even the framework for violence and terrorism differs depending on the sectarian origin. The hierarchical structure of the Shi'a community and its political organizations means that targeted violence is much more likely to be tied to specific policies. Organizationally there tends to be a 'rational' decision process to support a particular tactical or strategic objective. Among the Sunni groups the political landscape is far more fractured. Independent groups spring up with their own agendas that are invariably tied to local or regional issues. In the case of Shi'a based terrorism, the agenda, no matter how objectionable, usually makes sense within a certain framework of interests and terrorist actions are not just random, isolated events. In contrast, the size and breadth of the Sunni community and general lack of a clear hierarchical structure makes Sunni-based terrorist activities far more random, far more improvised and far more frustrating to combat. Violent terrorist organizations are functions of local and regional conflicts and issues, and must be understood as such. Lumping groups together because they are all Muslims distorts understanding the issues, the groups, and how to combat them. An evaluation of the local political, economic, social, and cultural dynamic, including an examination of the role of the various brands of Islam involved, provides a deeper understanding and improved context for evaluating and predicting the potential for conflict in the Islamic world. This also applies to the nature of that conflict, whether a tool in a defined state or group strategy, or as a much less defined fractional approach to gaining political leverage. 


\section{Conclusion}

$\mathrm{T}$ he key to a realistic perspective on Islam and Islamic societies lies in an understanding the granularity of Islam as a reflection of the heterogeneous environments in which it exists; its own conflicted and diverse development and structure; the often misunderstood American odyssey in the Islamic World; and the contemporary state of conflict within the Islamic world. These different aspects of Islam are important to the contemporary challenges and dilemmas faced by the United States and SOF. They underscore the difficulties associated with developing a consistent, viable set of policies in the post-9/11 environment and offer some ideas on a modified framework from which to consider the relationship between the very complex issues of geopolitical structures, socioeconomic influences, and cultural differences within the Islamic World. They also have direct applicability to how SOF intelligence and operations need to approach the issue.

Islam is the ideological façade for concrete problems. Viewing the Islamic world in terms of large subsets, Sunni, Shi'a, Kharijite, et cetera, is misleading. Granularity is the key. It is important to any understanding of Islam in a radicalized environment-historical, political, economic, social, and cultural issues almost always trump theology. A deep understanding of these issues is critical to SOF. After over a decade of war in the region, SOF are well aware of the heterogeneous nature of Islam at least at the macro-level, but the continuing struggle requires an increasingly detailed understanding of its nuances.

Elevating the priority of a deeper contextual understanding of Islam presents challenges. First, after over a decade of deployments in the Islamic world, a tendency to apply broad labels to Islamic groups remains. Labels like al-Qaeda provide ready-made categories for lumping hostile groups and movements together, but a more detailed understanding of these groups often reveals wedge-issues and leverage-points that can be used to weaken and compromise them. The second challenge is the propensity to see Islam as the issue rather than the particular political, economic, social, and cultural context, where in reality it serves as the ideological shell. Islam and the language of Islam comprise a veneer that masks endemic local and regional problems. 
In spite of the central role of the universal caliphate in Islamic political consciousness, for most of the last fourteen centuries the actual government of Muslim territories took place within far smaller arenas than the whole Community of Believers and under rulers whose claims to religious leadership were exiguous at best. ${ }^{183}$

The events of 9/11, created a new enemy for the West-Islamic terrorand initially transposed simplistic Cold War paradigms to Islam. Since that time, the military in general and SOF in particular have become acutely aware that there are differences in the Islamic landscape. But even this awareness often lacks understanding of the deeper granularity of Islam in the specific geopolitical environment where it is encountered. The primary problem is not in ideology, but rather local in nature. Conflict arises from an acute sense of injustice from which a toxic mixture of ideology or religion and extremist political postures fosters instability, insurgency, and terrorism. Understanding the relationship between alienation, ideology, and political radicalism is the first step in protecting U.S. interests and combating VEOs and limiting terrorism. In addition, understanding on the front end that it is highly unlikely that the underlying injustices will disappear makes it equally unlikely that terror as a tool can be eliminated-it can only be limited.

Generalizations about terror and Islam are counterproductive. In an article entitled, "Name Calling," Steve Coll discusses al-Qaeda and points out, "Each group has a distinctive local history and mostly local membership. None have strong ties to 'core al-Qaeda'," meaning Ayman al-Zawahiri, Osama bin Laden's successor. They may have ties to operatives but it is hardly a formal command and control environment. Coll's point is that just because a group calls itself al-Qaeda and is violently anti-Western does not mean that it is really a part of a functioning larger organization. In fact, conceptualizing it in that way hampers understanding within its specific ideological, political, economic, and social framework. Al-Qaeda was intended to be a pan-Islamic movement that transcends sectarian divisions, while in reality those calling them al-Qaeda have motivations and ideological mantras that reflect narrow local and regional norms. Coll states that he fears that U.S. efforts are poorly defined and even more poorly understood, "A war against a name is a war in name only." ${ }^{184}$ Labels often promote over simplification and inhibit grappling with the details that provide the understanding to coopt, neutralize, or destroy violent threats to U.S. interests. 
In some ways, Muslims themselves bear responsibility for the generalizations because of how they prefer to view themselves. The Muslim ideal self-image of the tawhid, or 'unity' of the community feeds a preexisting Western modality of thought about threats. In the Muslim world, wars and pronouncements by some political and religious leaders support the view of Western values as a threat to Islam.

The propagation of an ideal self-image within the Islamic world provides a similar distortion. Conceptually, Islam is grounded in the concept of tawhid. The 'oneness' of God was central to the monotheistic revelation that the Prophet transmitted to the umma. The idea of unity applied to the fractured political landscape became central to multiple facets of Islamic life. This fractured landscape constitutes an embarrassment to members of a community in which the concept of unity is so central. The rhetoric of unity does not match the situation on the ground. SOF must understand that it is the environment and relationships within which a person or group functions that is important and how belief or ideology overlays that environment.

The reality of multiple sects and ideological structures within Islam and the conflicts within the umma or Islamic community fuels self-conscience rhetoric about unity as well as the ideological drivers behind fundamentalist and salafi political groups and movements that seek to impose this unity-an idea that Islam existed in an ideal or purer form accompanied by a conscious effort to recreate that society. Fundamentalist Islam shares many of the same attributes of fundamentalist movements in other religions. Idealizing the past is for any religious group problematic because the past that they seek is often more imagined than real. Tawhid among the umma is a great ideal, but historically one would be hard pressed to make the case that it ever actually existed. This issue is not unique to Islam. Judaism and Christianity have always been riven by factionalism and conflict.

An individual's grasp of Islamic development and the sources of contemporary conflict can provide useful indicators about political and religious predispositions. More importantly, some basic knowledge about the sources of conflict is critical to understanding not only individuals but also the broader political and cultural milieu of a region. When Muslims talk about the current crisis in Islam-or particularly when Islamists blame the situation in the Islamic world on Western influence or the United States-it is useful to bear in mind that the contemporary situation is a reflection of the ongoing conflict within Islam itself. 
The U.S. military in general, and SOF in particular, find themselves thrust into the middle of a conflict in which they are outsiders in a sea of competing Islamist groups. The U.S. position relative to Islam has shifted over the last three decades. The crisis of 1979, the end of the Cold War, and massive increase in the U.S. presence in the Islamic world made the U.S. the focal point for Muslim frustrations in the region. At the same time, U.S. policy often seemed to function entirely independent of the interests of allies and U.S. policy often appeared poorly conceived or calculated. In the first decade of the 21st century, the U.S. finds itself the most unpopular nation by far among Muslims and the focus for biting criticism from friend and foe alike. ${ }^{185}$ Understanding the U.S. position relative to conflict in the Islamic world is critical. It is important to understand that the very forces with which we contend today have often been our allies in the past, but interests have changed.

The differing ideological aspects of Islam provide a better understanding not only of the real nature of specific areas of conflict and instability, but also the motivations of VEOs. In the Shi'a community, focused violence almost always fits into a broader strategy associated with quasi-realistic political goals and political agendas, while Sunni-based terrorist activities are more random and improvised. Whether it emanates from Tehran, Lebanon, or Iraq, Shi'a-centered terrorism is the product of more hierarchical political and related religious structure. In contrast, the diffused nature of Sunni Islam often pits non-state actors and marginal splinter groups against established governments. The size of the Sunni community and lack of effective hierarchical system that delineates religious and political authority make violent Sunni organizations much more difficult to counter. Terrorism as a tactic must be analyzed within the political and cultural context in which it occurs. The U.S. military and SOF in particular are involved in an ongoing conflict the roots of which often predate the advent of Islam itself-a conflict about power and influence where Islam has added an additional complex level of ideological justification. $\uparrow$ 


\section{Endnotes}

1. M. Saleem Kidwai, U.S. Policy Towards the Muslim World: Focus on Post 9/11 Period (Lanham, Maryland: University Press of America, 2010), ix.

2. White House website, http://www.whitehouse.gov/sites/default/files/rss_viewer/ national_security_strategy.pdf, accessed 28 May 2014.

3. Philip H. Gordon, Winning the Right War: The Path to Security for America and the World (New York: Henry Holt and Company, 2007): 22.

4. A field grade SOF officer with multiple tours in Afghanistan and Iraq. Also see "The tragedy of the Arabs," The Economist (July 5, 2014): 9-10, in which the article argues: "Islam, or at least modern interpretations of it, is at the core of some of the Arabs' deep troubles." The argument then proceeds to take an overt "orientalist" tone stating more or less that if Muslims were more like the West then they would not have all these problems. It is cultural-centric Western views of other cultures, Islamic or otherwise, that make it extremely difficult for Western policy, and particularly U.S. policy, to succeed in much of the developing world because there is this naïve mantra that cultures that have their own context and conflicts must mimic the West to succeed. Thus, the West attempts to impose westernstyle democracy where it has never existed; the West denigrates monarchy where it has functioned well for centuries; and we offer advice-political, social and even technical-that merely exacerbates the preexisting stresses present in the society. As for the Islamic world, in virtually every case, modernization is the goal, not westernization; the two are not synonymous.

5. Brian Michael Jenkins, Al Qaeda in its Third Decade: Irreversible Decline or Imminent Victory (Arlington, VA: Rand Corporation, 2012): 3.

6. Conversation with a senior Arab Gulf military officer, January 2013.

7. Marshall G.S. Hodgson, The Classical Age of Islam Volume One in The Venture of Islam: Conscience and History in a World Civilization (Chicago: University of Chicago Press, 1977): 233.

8. Shibely Telhami, Principal Investigator, 2010 Annual Arab Public Opinion Survey, Anwar Sadat Chair for Peace and Development - University of Maryland with Zogby International, August 5, 2010.

9. Voll, Islam Continuity and Change, 175-177. Miles Copeland, The Game of Nations, The Amorality of Power Politics (New York: Simon \& Schuster, 1969): 214-218. Miles Copeland was a contractor supporting CIA operations in the Middle East. Copeland's account of various reactions to the Eisenhower Doctrine is entertaining. First, he quoted a member of the U.S. Middle East Policy Planning Committee asking the CIA, "Would you fellows like to send someone along on the mission that's going out to explain it to the Arab chiefs of state? We can't afford to associate ourselves with every lunatic scheme that comes along." $\mathrm{He}$ quotes Nasser as saying, "The genius of you Americans is that you never make clear-cut stupid moves, only complicated stupid moves which make us wonder 
at the possibility that there may be something to them we are missing." Complicated or not, Copeland points out that the term "wave of the future" became synonymous with Nasser and widely used. In 2003, in interviews with Phillips Talbot, General Andrew Goodpaster, William "Bill” Lakeland and Walt Rostow, each used the term at one point or another to describe the U.S. evaluation of Nasser and the Nasserist wave that seemed to be sweeping the Arab Middle East.

10. In the region, the Iran-Iraq War (1980-1988) is viewed as the First Gulf War, with the war that resulted from the Iraqi occupation of Kuwait (1990-1991) being the second. The U.S. invasion of Iraq is the Third Gulf War (2003-2011).

11. Albert Hourani, Arabic Thought in the Liberal Age, 1798-1939 (Cambridge: Cambridge University Press, 1987): 373.

12. Hasan al-Banna, "New Renaissance: The Viewpoint of the Muslim Brotherhood" in Political and Social Thought in the Contemporary Middle East by Kamal H. Karpat (New York: Frederick A. Praeger, Publishers, 1968): 115-122.

13. Although this will be discussed at length later, it is appropriate here to point out two examples of attempted universalism: Khomeini and Osama bin Laden's visions for a pan-Islamic movement. One represented the ultimate form of the Shi'a political and religious structure based on the theory of wilayat-e fiqh, guardianship of the Islamic community, and the other the simplistic, violent zealotry of a pampered loner postulating about creating an impractical unattainable universal, pan-Islamic Caliphate that had its ideological roots in radical Nejdi Islam. The Khomeini vision failed, tainted by Shi'a exceptionalism, and Bin Laden's global Caliphate degenerated into geographically and ideologically diverse groups that have adopted the violent tactics of Al Qaeda but whose aims reflect the issues of local conflict. Abu Musab al-Zarqawi intentionally sparked a sectarian war in Iraq that flew in the face of Bin Laden's grandiose theories about a universal Caliphate and his erstwhile superior's wishes-the local political environment trumped religious utopianism.

14. Washington Post, September 20, 2011, "President George Bush Addresses the Nation:" full text of President Bush's address to a joint session of Congress and the nation. http://www.washingtonpost.com/wp-srv/nation/specials/attacked/ transcripts/bushaddress_092001.html

15. Benedict Anderson, Imagined Communities (London: Verso Books, 2006): 16, 160. Anderson's work is a challenging look at modern nationalism and its effect on global communities. He views it as selling a myth unity to communities whose interests are fundamentally different-the creation of imagined communities and argues that the real surprising issue is not that adherents to these imagined communities are willing to kill for a myth but that millions have been willing to die for one. In fact, Anderson argues that historically the most proficient state at promulgating the "myth" has been the United States.

16. Voll, Continuity and Change, 16.

17. Hugh Kennedy, The Prophet and the Age of the Caliphates: The Islamic Near East from the Sixth to the Eleventh Century (London: Longman, 1994): 44. 
18. Ibid., 50-51, 69-75.

19. S. Husain M. Jafri, Origins and Early Development of Shi'a Islam (Beirut: Librairie du Liban, 1981):11-23.

20. L.W. Adamec, Islam-A Historical Companion (Stroud, U.K.: Tempus Publishing Limited, 2007): 45.

21. Ira M. Lapidus, A History of Islamic Societies (Cambridge: Cambridge University Press, 1988): 60.

22. See Roby C. Barrett, Oman: The Present in the Context of a Fractured Past (MacDill Air Force Base, Florida: JSOU Report 11-5, 2011) for a more detailed description of Kharijite theological and political development.

23. Lapidus, A History of Islamic Societies, 60.

24. Ibid., 61.

25. John Esposito, The Oxford History of Islam (London: The Oxford Press, 1999): 35. The Umayyad Caliphate (661-750) dated from the death of the last Rashiduun Caliph Ali or the first Imam in the Shi'a tradition.

26. Wendell Phillips, Oman: A History (London: William Morrow \& Company, 1962): 9.

27. Hodgson, The Classical Age of Islam, 269-271.

28. Lapidus, A History of Islamic Societies, 65.

29. Ibid.

30. Ibid., 87.

31. Ibid., 64 .

32. Kennedy, The Age of the Caliphates, 117.

33. Ibid., 121.

34. Jonathan Berkey, The Formation of Islam: Religion and Society in the Near East, 600-1800 (Cambridge: Cambridge University Press, 2011): 75-82.

35. Kennedy, The Age of the Caliphates, 112-116.

36. Ibid.

37. Ibid., 116-118.

38. Farhad Daftary, A Short History of the Ismailis (Princeton: Marcus Wiener Publishers, 1998): 30.

39. Dawud Walid, "What American Muslims Can Learn from Uprisings," Weblog of Dawud Walid (February 18, 2011): http://dawudwalid.wordpress.com/2011/02/18/ what-american-muslims-can-learn-from-uprisings/.

40. Kennedy, Age of the Caliphates, 112.

41. Lapidus, A History of Islamic Societies, 67.

42. The Abbasids had done the utmost to eliminate all the Umayyad princes and Abd-al-Rahman experienced numerous narrow escapes. After making his way to Spain, he then faced serious opposition as well as continued Abbasid attempts 
to eliminate him. The Umayyads conquered Spain in 711 and their expansion was eventually stopped by overextended political and military commitments and the defeat of a Muslim expeditionary at Poitier, France, in 732 by Charles Martel (the Hammer). Thus, by the time of Abd-al-Rahman's arrival Spain had been controlled for roughly four decades from Damascus.

43. Anwar E. Chejne, Muslim Spain: Its History and Culture (Minneapolis: University of Minnesota, 1974): 15, 35.

44. Hugh Kennedy, When Baghdad Ruled the Muslim World: The Rise and Fall of Islam's Greatest Dynasty (London: De Capo Press, 2006): 1-33.

45. Ibid., 37.

46. Ibid., $37,77$.

47. Kennedy, Age of the Caliphates, 155.

48. Ibid., 163. Ahmad Ibn Hanbal (780-855) is the namesake of the fourth major school of Sunni Islamic thought. His theological position relative to the policies of Caliph al-Mamun earned him a lashing as well as a following. His students formalized his religious beliefs into what would become the theological and ideological base for the most conservative branch of Sunni Islam. Taqi ad-Din Ahmad ibn Taymiyya (1263-1328) and Muhammad ibn Abd-al-Wahab (17031792) used Hanbali thought and theology as a basis for their reformist movements. It would be the alliance between the Al Saud and Abd-al-Wahab in 1744 that brought into existence the First Saudi State and continues to the governing school of Islamic theology in Saudi Arabia and Qatar, and strongly influences Salafi Islamic movements around the globe.

49. Patricia Crone, "The Abbasid Abna and Sassanid Cavalry," The Journal of the Royal Asiatic Society of Great Britain and Ireland (Volume 8, Issue 1, 1998): 1-19. The Abna in the Abbasid army were assumed to be the descendants of the Khorasanis that placed the Abbasids on the throne. More recently, some have argued that the Abna were not "Sons of the Revolution", but rather the descendants of Sassanian horsemen from the lesser nobility that formed cavalry units. The revolutionary troops consisted primarily of such recruits. They eventually emerged as distinct social group with their own political interests that by alMamun's time conflicted with those of the Caliph.

50. Kennedy, Age of the Caliphates, 164-165.

51. Kennedy, When Baghdad Ruled, 260.

52. Shibely Telhami, Principal Investigator, 2010 Annual Arab Public Opinion Survey, Anwar Sadat Chair for Peace and Development - University of Maryland with Zogby International, August 5, 2010.

53. USDEK was the acronym for Undang-Undang Dasar '45 (Constitution of 1945), Sosialisme Indonesia (Indonesian socialism), Demokrasi Terpimpin (Guided Democracy), Ekonomi Terpimpin (Command Economy), and Kepribadian Indonesia (Indonesia's Identity). 
54. James Lambert, The Barbary Wars: American Independence in the Atlantic World (New York: Hill and Wang, 2005): 7-9. Lambert argues that the Barbary Wars underscored that if the United States wanted to benefit from global trade that it would have to protect its commercial interests, but he clearly deplores interpretations that focus on ideology or radical Islam as the principle or even an important issue in the war. Early treaties with the Barbary Pirates did not even mention religion. The author places the Barbary Wars within the global context. It was a continuation of the War for Independence that included the British Mercantile system, a naval war with France, and the War of 1812 as well as the struggle with the North African pirates.

55. “Jefferson to John Jay, March 28, 1786," Thomas Jefferson Papers, Series 1. General Correspondence. 1651-1827, Library of Congress.

56. Richard Zacks, The Pirate Coast: Jefferson, the First Marines, and the Secret Mission of 1805 (New York: Hyperion, 2005): 7, 269-316. Having been named Consul to Tunis, Eaton's assessment of his new duty station indicates his less than positive view of the situation and his assignment: "Here I am ... under the mad rays of a vertical sun reflected and refracted from wall and terraces of white-washed houses, hotter than tobacco \& rum, with plague and scorpions suspended over my head, menacing death, surrounded by brutal Turks, swindlers, jews, perfidious Italians, miserable slaves, lazy camels, churlish mules, and savage arabswithout society and without amusement. Is not this enough to constitute a hell?"

57. Thomas M. McKenna, "Appreciating Islam in the Muslim Philippines: Authority, Experience, and Identity in Cotabato," in Islam in the Era of National-States: Politics and Religious Renewal in Muslim Southeast Asia edited by Robert W. Hefner and Patricia Horvatich (Honolulu: University of Hawaii, 1997): 56.

58. Brian McAllister Linn, The U.S. Army and Counterinsurgency in the Philippine War, 1899-1902 (Chapel Hill: The University of North Carolina Press, 1989): 10. This is an excellent book on the insurgency in the Philippines and the evolution of U.S. tactics to defeat it. See page 169; Linn made a most interesting observation about the way in which the U.S. Army ultimately fought from a command and control perspective: "By relying, albeit unintentionally, on the intelligence and ability of its garrison and provincial commanders, the U.S. Army threw the burden of pacification on the very people who had to deal with it. In the Philippines there were no helicopters or radio communications to insure that each subordinate followed his instruction to the letter. Most officers were isolated, and in some areas it took almost six months for an officer's superiors to read his situation reports and comment on them. This lack of official control aided pacification. It not only forced individual officers to be responsible for the pacification of their areas, but also prevented interference from their superiors, particularly in Manila."

59. Ibid., 11-17.

60. Ibid., 20 . 
61. Brian McAllister Linn, The Philippine War, 1899-1902 (Lawrence: The University of Kansas Press, 2000): 180, 322-328. The revision view of the U.S. role and particularly that of the army in the Philippines has argued that it was fundamentally a racist, imperialist campaign against popular indigenous revolutionary forces. Linn's work provides balance to this view. With limited forces, the U.S. command showed a remarkable degree of creativity with the limited forces at its disposal. In contrast, the Filipino army commanders were remarkably inept. In 1983, Glenn A. May, a critic of U.S. policy, stated, "from a purely military perspective, the U.S. victory in the Philippines was due more to the mistakes of the enemy than the cleverness of the U.S. command." In short Aguinaldo's leadership was "inept" and his grassroots support "lukewarm" at best. The war was neither "the imperialist myth" of Americans saving the Filipinos from revolutionary tyranny nor the revisionist view that the U.S. Army was a "brutal and racist soldiery slaughtering defenseless natives." Linn argues that the truth is something far more complex just as insurgencies and campaigns against them are complex.

62. Interview by Nermeen Shaikh with Thomas McKenna, University of California at Berkeley "Muslim Separatists in the Southern Philippines," The Asia Society: http://asiasociety.org/policy/governance/national/ muslim-separatists-southern-philippines.

63. Ibid.

64. Brian McAllister Linn, Guardians of Empire: The U.S. Army and the Pacific, 1902-1940 (Chapel Hill: The University of North Carolina Press, 1997): 35.

65. Ibid.

66. Ibid., 38-41.

67. Ibid.

68. David Fromkin, A Peace to End All Peace: Creating the Modern Middle East 1914-1922 (New York: Henry Holt and Company, 1989): 403-411, 558-567.

69. Daniel Yergin, The Prize: The Epic Quest for Oil, Money, \& Power (New York: Simon \& Schuster, 1992): 280-302.

70. John Lewis Gaddis, The United States and the Origins of the Cold War, 1941-1947 (New York: Columbia University Press, 1972): 8-13.

71. Europe and Japan were the primary issues for Washington. Japan lost all of her extra-territorial possessions when it surrendered. For the Europeans, the issue was more complicated. In the case of France, the U.S. insisted that it vacate Lebanon and Syria and began to pressure Paris about North Africa, particularly Tunisia and Morocco. Algeria was a particularly complicated issue-although a clear colonial possession, the French had made it an actual department in metropolitan France. See Alistair Horne, A Savage War of Peace: Algeria 19541962 (New York: Penguin Books, 1979): 44-59. The second chapter, "Ici, c'est la France" provides a brief but accurate description of immediate post-war Algeria that goes far to explain the problem. Horne's book is still the best single volume on the war and independence in Algeria. It would be a painful decade-and-ahalf and a near revolution in France before Algeria became independent. W. 
Roger Louis, The British Empire in the Middle East 1945-1951 (Oxford: Oxford University Press, 1984): 54-102. Louis' work lays out the various schemes through which the British hoped to maintain their influence in the Arab Middle East and Persian Gulf under the Labour government of Clement Attlee, 1945-1951. He points out that Attlee's government had no desire to pull out of the Middle East or to allow independent states in the region to pursue policies detrimental to British interests. Rather, the Labour government hoped to use regional collective security arrangements to maintain its influence and indirect control. In 1951, Churchill returned to power. Churchill's overarching foreign policy goals, namely British influence and control, were the same as Attlee's; Churchill was merely more willing to use coercive means to accomplish them.

72. "Diary Entry by President Eisenhower concerning a conversation with British Prime Minister Churchill, 6 January 1953," Dwight David Eisenhower Library (DDEL), Presidential Papers of Dwight David Eisenhower (PPDDE), Anne Whitman File (AWF), Ann Whitman Diary (AWD) Series, Box 9: 6-7.

73. Ibid.

74. Ibid., Box 9: 7.

75. "Diary Entry by Eisenhower concerning a foreign policy meeting with Dulles, 10 January 1953," DDEL, AWF, AWD Series, Box 9: 2. See also “Diary Entry by Eisenhower comments on discussions with Anthony Eden, British Foreign Secretary, 8 February 1953," DDEL, AWF, AWD Series, Box 9: 2.

76. "Minutes from the 133rd National Security Council meeting, 24 February 1953," DDEL, PPDDE, AWF, National Security Council (NSC) Series, Box 4: 2.

77. "Minutes from the 132nd NSC meeting, 19 February 1953," DDEL, PPDDE, AWF, NSC Series, Box 4: 2. See also Eisenhower, Dwight D. Eisenhower: The White House Years, Mandate for Change, 1953-1956, 159-166. In his memoirs, President Eisenhower voiced his "confidence that the 'young Shah' would prove an effective leader of his people." The Shah's weakness in confronting Musaddiq turned Washington's focus to General Zahedi, as the real source of stability.

78. "Minutes from the 135th NSC meeting, 5 March 1953," DDEL, PPDDE, AWF, NSC Series, Box 4: 5.

79. "Minutes from the 136th NSC meeting, 12 March 1953" DDEL, PPDDE, AWF, NSC Series, Box 4: 14.

80. "Summary of Reactions to PSB D-22, 'Psychological Strategy Program for the Middle East', Appendix A, May 1953," DDEL, PPDDE, White House Office Files (WHO Files), NSC Staff Papers 1948-1961, OCB Central Files Series, Box 77: 8.

81. Ronald W. Ferrier, "The Anglo-Iranian oil dispute: a triangular relationship," in Musaddiq, Iranian Nationalism, and Oil edited by James A. Bill and William Roger Louis (London: I.B. Tauris \& Co. Ltd., 1988): 190.

82. "Minutes from the 178th NSC meeting, 30 December 1953," DDEL, PPDDE, AWF, NSC Series, Box 5: 3-6. 
83. Shahrough Afhavi, "The Role of the Clergy in Iranian Politics, 1949-1954," and Farhang Rajaee, "Islam, Nationalism and Musaddiq's Era: Post-revolutionary Historiography in Iran," in Musaddiq edited by Bill and Louis, 1988. The Shi'a clergy played a significant role in the fall of Musaddiq, and the use of Islamic influence in the Cold War struggle against the Soviet Union, and various Communist and Socialist groups became a standard feature of U.S. policy, reaching its apogee in the Afghan War of the 1980s. See also James A. Bill, The Eagle and the Lion: The Tragedy of American-Iranian Relations, New Haven: Yale University Press, 1988: 51-72. Bill stated that the defection of Ayatollah Abul Qassim Kashani from the Musaddiq was "the major blow." Musaddiq became more dependent on the leftist parties and the Tudeh.

84. Interview with Phillips Talbot, New York City, 31 May 2003.

85. Dennis Kux, The United States and Pakistan, 1947-2000 (Baltimore: The Johns Hopkins University Press, 2001): 93-95.

86. Kux, The United States and Pakistan, 98-100.

87. Steve Coll, Ghost Wars: the Secret History of the CIA, Afghanistan and Bin Laden, from the Soviet Invasion to September 10, 2001 (New York: Penguin Press, 2004): 24.

88. Adrian Vickers, A History of Modern Indonesia (Cambridge: Cambridge University Press, 2010): 117. In their original form these principles were structuring a Free Indonesia in Faithfulness to God Almighty, Consensus or Democracy, Internationalism or Humanitarianism Social Prosperity, and Nationalism or national unity. Sukarno introduced this platform in 1945.

89. Ibid., 151.

90. Antonie C. Dake, Sukarno Files 1965-1967: Chronology of a Defeat (Leiden: Brill Academic Publishers, 2006).

91. James Srodes, Allen Dulles, Master of Spies (Washington, D.C.: Regnery Publishing, Inc., 1999): 460-461. In Washington, Kermit Roosevelt refused to participate in schemes to over throw Nasser. Roosevelt stated, "I tried to tell them that these operations never work, if you are going against the grain of events. You have to have so much going your way before you dare undertake them. First and foremost, you have to have the vast majority of the people behind you. We did in Iran. And you have to have a leadership that is better than the one in power and one that can take control. We had in Iran in the army and the power structure; and the shah himself was a very gentle and reasonable person, although later he turned into a tough customer." Roosevelt advised the White House to get used to Nasser because the Iranian option simply did not exist.

92. “Telegram from Dulles in Baghdad to Eisenhower, May 17, 1953," DDEL, PPDDE, AWF, Dulles-Herter Series, Box 1: 1. An Interview with William C. Lakeland, Berkeley, California, 23-24 September 2003.

93. Anthony Nutting, Nasser (New York: E.P. Dutton \& Co., Inc., 1972): 70-73. When a member of the Brotherhood attempted to assassinate Nasser in October 1954, 
he used the incident as justification to crush the Brotherhood and his other political opponents.

94. Muhammad Heikal, The Cairo Documents (New York: Doubleday and Company, Inc., 1972): 54.

95. Anouar Abdel-Malek, Egypt: Military Society - The Army Regime, the Left, and Social Change under Nasser (New York: Random House Inc., 1968): 227.

96. Interview with Muhammad Hakki, Washington, D.C., 8 August 2003. Muhammad Hakki graduated from Cairo University in 1954. In 1955, he became information officer at the Egyptian embassy in Cairo. He would later work for Muhammad Hussein Heikal at Al-Ahram during the height of the Nasserist era.

97. Nutting, Nasser, 101.

98. "Dispatch from Indian Embassy Jakarta (Ambassador BFHB Tyabji) to S. Dutt, Commonwealth Affairs Secretary, New Delhi, on Impressions of the Bandung Conference, 28 April 1955," National Archives of India (NAI), Middle East Affairs (MEA), Section: Asian-African Conference, File: 1(37)—AAC/55: 4. See also Asian-African Conference, 18-24 April 1955: Prime Minister Jawaharlal Nehru's Speeches and the Final Communiqué from the Publications Division of the Ministry of Information and Broadcasting (New Delhi: Government of India Press, 1955) found in the India collection at the Australian National Library (ANL).

99. "Letter from Chairman Senate Foreign Relations Committee (Humphrey) to Assistant Secretary NEA (Rountree), 9 April 1958," NACPM, GRDOS-59, NEA, CDF 1955-1959, 611.86/4-958 (Box 2555): 1.

100. "Discussion at the 373rd Meeting of the NSC, 24 July 1958," DDEL, PPDDE, AWF, NSC Series, Box 10: 3-4, 9.. See also Charles Tripp, A History of Iraq (Cambridge: Cambridge University Press, 2000): 177.

101. See Malcolm Kerr, The Arab Cold War 1958-1967, A Study of Ideology in Politics (London: The Oxford University Press, 1967).

102. Interview with General Andrew Goodpaster, August 8, 2003.

103. Muhammad Hussein Heikal, The Sphinx and the Commissar: The Rise and Fall of the Soviet Influence in the Middle East (New York: Harper \& Row Publishers, 1978): 104.

104. "Memorandum from the Assistant Secretary of State for NEA (Rountree) to Acting Secretary of State Dillon, 22 December 1958," FRUS, 1958-1960, Near East Region, Volume XII: 370. See also "Memorandum of Discussion at the 392nd Meeting of the National Security Council, 23 December 1958," FRUS, 1958-1960, Near East Region, Volume XII: 372-374.

105. Robert St. John, The Boss: The Story of Gamal Abdul Nasser (New York: McGraw Hill, 1960): 301.

106. “Telegram from British Embassy Baghdad to FO, 25 March 1959," (No. 261) (Eq1017/11) PRO, FO371/140711: 1. 
107. See also, John S. Badeau, The Middle East Remembered (Washington, DC: The Middle East Institute, 1983), pp. 205-206.

108. Interview with Lakeland, 23-24 September 2003.

109. Hanna Batatu, The Old Social Classes and the Revolutionary Movement of Iraq: A Study of Iraq's Old Landed and Commercial Classes and of it Communists, Ba'thists and Free Officers (Princeton: Princeton University Press, 1978): 806, 982-987.

110. See Roby C. Barrett, Yemen: A Different Political Paradigm in Context (JSOU Press 2011) for a more detailed explanation of the fall of the Imamate and lists of other sources.

111. This study focuses on the Islamic world but there were other crisis including the leftist insurgencies in Central America.

112. James A. Bill, The Eagle and the Lion (New Haven: Yale University Press, 1988): 440-448.

113. Sluglett, Iraq Since 1958, 255-257.

114. Dilip Hiro, The Essential Middle East: A Comprehensive Guide (New York: Carroll \& Graff Publishers, 2001): 439. See also Peter L. Bergen, The Longest War (New York: Free Press, 2011), 13, 23.

115. F. Gregory Gause III, Saudi-Yemeni Relations: Domestic Structures and Foreign Influence (New York: Columbia University Press, 1990): 133-134.

116. Yaroslav Trofimov, The Siege of Mecca: The Forgotten Uprising (London: Allen Lane, -- Penguin Books, 2007): 38, 48-49.

117. "1979, Mob destroys U.S. embassy in Pakistan," BBC.com-On This Date (November 21, 1979): http://news.bbc.co.uk/onthisday/hi/dates/stories/november/21/newsid_4187000/4187184.stm

118. Kux, United States and Pakistan, 242-245.

119. Ibid., 256-275. Arguably no war in Afghanistan has ever been won by the invader and all foreigners at one point or another become invaders from an Afghan point of view. The Soviets might have achieved a situation similar to that facing the U.S. in 2013-an equilibrium between government and anti-government forces and spotty security around the country, but with the U.S. intervention and the partial loss of control of the air even that became impossible.

120. Victoria Clark, Yemen: Dancing on the Heads of Snakes (New Haven: Yale University Press, 2010), 143-144, and Senior Gulf Arab diplomat familiar with the politics familiar with internal Yemen affairs.

121. Thomas M. McKenna, Muslim Rulers and Rebels: Everyday Politics and Armed Separatism in the Southern Philippines (Berkeley: University of California Press, 1998): 275.

122. There have been attempts by some to define the "life-cycle" of terrorist campaigns in books, presentations, and policy discussions over the last decade. Audrey Kurth Cronin's work, How Terrorism Ends: Understanding the Decline and 
Demise of Terrorist Campaigns (Princeton: Princeton University Press, 2009), is one example. While it may be an interesting intellectual exercise, defining the "life-cycle" of terror campaigns as opposed to discussing political campaigns that employ terror is misleading. Terror is not the genesis of the problem-it does not have a life-cycle and the underlying political, economic, social, and cultural catalysts that create movements that employ terrorism as a tactic have an indefinite or even perpetual life-cycle that is only intensifying.

123. Gordon, Winning the Right War, xix.

124. Wajahat Ahmad, "Ghosts Of 9/11: Muslim Nationality Movements or Pan-Islamic Jihad,” Countercurrents.org (July 29, 2008): http://www.countercurrents.org/ ahmad290708.htm.

125. Rola el-Husseini, "Resistance, Jihad, and Martyrdom in Contemporary Lebanese Shi's Discourse," The Middle East Journal (Summer 2008): 414.

126. “The Sultan's Sabah Swing," The Economist, February 23, 2013: 39. See also Simon Roughneen, "Is historical claim behind the mystery group of (armed?) Filipinos in Borneo?" The Christian Science Monitor, February 15, 2013 download at http://www.csmonitor.com/World/Global-News/2013/0215/Is-historical-claimbehind-the-mystery-group-of-armed-Filipinos-in-Borneo. A recent incident in Malaysian Borneo provides an example of the fractious nature of Sunni Islam and how very small groups and causes can serve as a rallying point for discontent. One hundred armed men arrived in the Sabah province of Borneo in Malaysia by boat from the Philippines. Some were claiming to be the descendants of the Sultan of Sulu, a Sultanate that at one time encompassed the southern Philippines, Brunei, and Malaysian Borneo. There are so many splinter Sunni Islamist splinter groups in the region that Malaysian and Philippine authorities were having difficulty identifying the group. Speculation was that it was the Moro National Liberation Front (MNLF). Others stated that it was a splinter group from the MNLF, the Moro Islamic Liberation Front (MILF), and some worried that the interlopers could be associated with Abu Sayyaf or just a criminal gang. Roughly one week later, the group had announced that they were the Royal Army of Sulu. The Economist made a point worth considering, "The Philippines remains awash with Muslim armed groups ... Militants will be difficult to root out from an environment so disorderly that some have the nerve to try to invade another country."

127. Humphrey, Between Memory and Desire, 146.

128. Marshall G.S. Hodgson, The Venture of Islam: Conscience and History in a World Civilization, Volume 3, The Gunpowder Empires and Modern Times (Chicago: The University of Chicago Press, 1974): 107, 109.

129. Esposito, History of Islam, 113.

130. Ibid., 114.

131. Hiro, Essential Middle East, 478.

132. Esposito, History of Islam, 114. 
133. "Sunni Islam,” Globalsecurity.org (Downloaded June 16, 2012): http://www. globalsecurity.org/military/intro/islam-sunni.htm

134. Efraim Karsh and Inari Rautsi, Saddam Hussein: A Political Biography (New York: Grove Press, 1991): 150-175.

135. Anna Mulrine, "US commander in Afghanistan sees 'significant' risk of Al Qaeda returning," Christian Science Monitor (July 17, 2014) http://www.csmonitor.com/ USA/Military/2014/0717/US-commander-in-Afghanistan-sees-significant-riskof-Al-Qaeda-returning-video

136. David P. Chandler, William R. Roff, John R.W. Smail, David Joel Steinberg, Robert H. Taylor, Alexander Woodside, David K. Wyatt, In Search of Southeast Asia: A Modern History edited by David Joel Steinberg (Honolulu: University of Hawaii Press, 1987): 43.

137. Ibid., 43.

138. Robert Pringle, Understanding Islam in Indonesia: Politics and Diversity (Honolulu: University of Hawaii Press, 2010): 47-49.

139. Chandler, In Search of Southeast Asia, 423.

140. Anthony H. Johns, "Indonesia-Islam and Cultural Pluralism" in Islam in Asia: Religion, Politics \& Society edited by John L. Esposito (Oxford: Oxford University Press, 1987): 203.

141. Pringle, Islam in Indonesia, 145-154. There were three other conflicts that did not fit this loose model-Aceh, a nationalist struggle; East Timor, which represented an overt attempt by the Suharto regime to expand by imperialism; and Papua, which had some of the local attributes of the first three-communal violence emerging from a rise in the Muslim population from about eight percent of the population to approximately one quarter. Papua and East Timor had special grievances dating from before the Dutch period. See Pringle, 155-158.

142. Ibid.

143. Ibid.

144. Ibid., 154-155.

145. Robert Cribb and Michele Ford, "Indonesia as an Archipelago: Managing Islands, Managing the Seas," in Indonesia beyond the Water's Edge: Managing an Archipelagic State edited Robert Cribb and Michele Ford (Singapore: Institute of Southeast Asian Studies, 2009): 6.

146. Kevin Sieff, "Afghan army struggles with lack of reach," The Washington Post (July 10, 2013) http://www.washingtonpost.com/world/asia_pacific/afghanarmy-struggles-with-lack-of-reach/2013/07/10/819637c8-e992-11e2-818e-aa29e855f3ab_story.html?wpmk=MK0000200

147. Vali Nasr, The Shia Revival: How Conflicts within Islam Will Shape the Future (New York: W.W. Norton \& Company, 2006): 25-29.

148. Ervand Abrahamian, Khomeinism: Essays on the Islamic Republic (Berkley: University of California Press, 1993): 21. 
149. Legitimacy is an important issue in Islam and genealogy is a tool in establishing or inventing legitimacy. In Shi'a Islam, the legitimacy of Imams is based on the ability to trace their bloodline back through the Alid genealogy or blood line back to Ali bin Abi Talib the first Shi'a Imam and the Fourth Rashiduun Sunni Caliph.

150. "Occultation" is the process through which the Shi'a believe that last Imam, whether in the Jafari or Ismaili line, became "hidden" as opposed to dying. In the system of belief, the Shi'a believe that last Imam has hidden himself and will return or reveal himself at the end of time and participate in the judgment of believers and non-believers. In Jafari, or Twelver Shi'a Islam, there is a major and minor occultation the intricacies of which are often hotly debated. In the meantime, the senior clergy will act the agent of the Imam on earth. This belief parallels in many respects the Christological arguments and views of the role of various Christian clergies as believers awaiting the "revelation" of the second coming.

151. Hiro, Essential Middle East, 485-486.

152. Abdulaziz Abdulhussein Sachedina, The Just Ruler in Shi'ite Islam: The Comprehensive Authority of the Jurist in Imamite Jurisprudence (Oxford: Oxford University Press, 1988): 213-214. See also, Abrahamian, Khomeinism, 134. When Khamenei succeeded Khomeini the regime admitted that he lacked the qualifications as marja but argued that his knowledge of "contemporary problems facing the Muslim world qualified him.”

153. Dexter Filkins, “After Syria: If the Assad regime falls can Hezbollah survive?” The New Yorker February 23, 2013: 49-57. A first rate article on Hezbollah attitudes during the early stages of their involvement supporting Assad.

154. Martin Kramer, “Syria's Alawis and Shi'sm: How Syria's ruling sect found Islamic legitimacy" from Shi'sm, Resistance, and Revolution (Boulder: Westview Press, 1987) (Downloaded June 1, 2012): http://www.geocities.com/martinkramerorg/ Alawis.htm.

155. Dilip Hiro, Dictionary of the Middle East (New York: St. Martin's Press, 1998): 10.

156. Avraham Sela, The Continuum Political Encyclopedia of the Middle East (London: The Continuum Publishing Group Limited, 2002): 39-40.

157. Adeed Dawisha, Arab Nationalism in the Twentieth Century from Triumph to Despair (Princeton: Princeton University Press, 2003): 86-87, 96-97. The minority Alawites used Ba'thism to rule Syria in the same way that the minority Sunnis used Ba'thism to rule Iraq. They outlawed sectarianism in politics and used the 'secular' mandate to suppress the majorities-the Sunni in Syria and the Shi'a in Iraq. Hence the longstanding animosity between Syria and Iraq that is until the U.S. replaced the Sunni state with a Shi'a state allied with Iran.

158. Lapidus, A History of Islamic Societies, 653-654.

159. Gary C. Gambill, "Syrian Druze: Toward Defiant Neutrality," Foreign Policy Research Institute, March 2013, https://www.fpri.org/articles/2013/03/ syrian-druze-toward-defiant-neutrality 
160. Sela, 264.

161. The old terminology, the Islamic State in Syria and Iraq (ISIS), is used for geographic clarity. The new terms are the Islamic State in the Levant (ISIL), which has now been superseded to some degree by the term, the Islamic State (IS).

162. James Risen, "Intrigue in Karzai Family as an Afghan Era Closes," The New York Times (June 3, 2012): http://www.nytimes.com/2012/06/04/world/asia/karzaifamily-moves-to-protect-its-privilege.html?pagewanted=all.

163. Scott Baldauf, "U.S. Legacy in Afghanistan: What 11 years of war has accomplished," The Christian Science Monitor (June 10, 2012): http://www.csmonitor. com/World/Asia-South-Central/2012/0610/US-legacy-in-Afghanistan-What11-years-of-war-has-accomplished. See also, "India, Iran has convergence of interests in Afghanistan," Webindia123.com (February 25, 2012): http://news. webindia123.com/news/articles/India/20120225/1934801.html. This article based on comment by Amin Saikal, the Head of the Center for Arab and Islamic Studies at the Australian National University in Canberra points out that both Iran and India supported the Islamic Front for the Salvation of Afghanistan, popularly known as the Northern Alliance, during the 1990s. Saikal points out that for political and economic reasons neither Iran nor India want to see the return of a radical Taliban regime to Kabul either as the ruling authority or as an influential partner in the Afghan government.

164. Jayanth Jacob and Sabhadra Chatterji, "Afghan-Iran Rail Link," The Hindustani Times (November 1, 2011): http://www.hindustantimes.com/StoryPage/ Print/763448.aspx. See also, Myrna MacDonald, "In the Scramble for Afghanistan, India Looks to Iran,” Reuters (July 6, 2010): http://blogs.reuters.com/pakistan/2010/07/06/in-scramble-for-afghanistan-india-looks-to-iran/ and http:// www.eurasianet.org/print/65503

165. Tim Arango, "Iran Presses for Official to Be Next Leader of the Shiites," The New York Times (May 11, 2012): http://www.nytimes.com/2012/05/12/world/ middleeast/iran-promotes-its-candidate-for-next-shiite-leader.html?_r=1\&pa gewanted=all\&pagewanted $=$ print.

166. Abdel Salam Sidahmed and Anoushiravan Ehteshami, Islamic Fundamentalism (Boulder: Westview Press, 1996): 10.

167. Ibid., 12 .

168. Bruce Riedel, "Israel's Dilemma: If it attacks Iran, will it also have to hit Hizbollah," The Daily Beast (February 9, 2012): http://www.thedailybeast.com/ articles/2012/02/09/israel-s-dilemma-if-it-attacks-iran-will-it-also-have-tohit-hizbullah.html. http://www.thedailybeast.com/articles/2012/02/09/israels-dilemma-if-it-attacks-iran-will-it-also-have-to-hit-hizbullah.html. "Sympathy for Persian Iran may be limited in the Arab world, but sympathy for Arab Lebanon would be higher, especially if Israel were to strike first. Israel can expect condemnation from many quarters for any attack on Iran; it would get more if it were also at war with Hizbullah (sic), and bombing Beirut." See also Adrian Blomfield, "Israel warns Hezbollah over Iran," The Telegraph (May 6, 2012): 
http://www.telegraph.co.uk/news/worldnews/middleeast/israel/9249171/Israelwarns-Hizbollah-over-Iran.html.

169. "Iran moves to bolster Iraq's beleaguered Premier Maliki," PBS-Frontline-Tehran Bureau (June 6, 2012): http://www.pbs.org/wgbh/pages/frontline/tehranbureau/2012/06/news-iran-moves-to-bolster-iraqs-beleaguered-premier-maliki.html.

170. Ali Abd el Amir, "Former Iraqi Prime Minister Wary of Iraq Becoming Dictatorship," Al Monitor (June 14, 2012): http://www.al-monitor.com/pulse/politics/2012/06/allawi-to-al-hayat-we-will-confr.html.

171. "Saudi Arabia: out of the comfort zone," The Economist (March 3, 2012): http:// www.economist.com/node/21548973/print.

172. Adeed Dawisha, Arab Nationalism in the Twentieth Century: From Triumph to Despair (Princeton: Princeton University Press, 2003): 5-7.

173. David George, "Pax Islamica: An Alternative new World Order?” in Islamic Fundamentalism edited by Abdel Salam Sidahmed and Anoushiravan Ehteshami (Boulder: Westview Press, 1996): 71-90.

174. Mehdi Mozaffari, "Islamism in Algeria and Iran," in Islamic Fundamentalism, 233, 237.

175. Abrahamian, Khomeinism, 59.

176. Joseph Wright Twinam, The Gulf, Cooperation, and the Council: An American Perspective (Washington, D.C.: The Middle East Policy Council, 1992): 10.

177. Saif bin Hashil Al-Maskery, "The Gulf Cooperation Council: Future Trends," in Iran, Iraq and the Arab Gulf States edited by Joseph A. Kechichian (New York: Palgrave, 2001): 397.

178. Glen Carey, "Gunfights in Saudi oil rich provinces show spread of Iran political tension,” Bloomberg (February 14, 2012): http://www.bloomberg.com/news/ print/2012-02-13/gunfights-in-saudi-oil-province-show-spread-of-iran-tensions. html. Helen Chapin Metz, ed. Iran: A Country Study. (Washington: GPO for the Library of Congress, 1987): http://countrystudies.us/iran/101.htm.

179. Steve Coll, The Bin Ladens: An Arabian Family in the American Century (New York: Penguin Press, 2008): 292-296.

180. Bergen, The Longest War, 16-18.

181. Daniel Benjamin and Steven Simon, The Age of Sacred Terror (New York: Random House, 2002): 140-143.

182. R. Stephen Humphreys, Between Memory and Desire: The Middle East in a troubled age (Berkley: University of California Press, 1999): 157.

183. Ibid., 162.

184. Steve Coll, “Comment - Name Calling," New Yorker (March 4, 2013): 17-18.

185. Shibely Telhami, Principal Investigator, 2010 Annual Arab Public Opinion Survey, Anwar Sadat Chair for Peace and Development - University of Maryland with Zogby International, August 5, 2010. 
